\title{
DESENVOLVIMENTO VEGETATIVO DA PUPUNHEIRA (Bactris gasipaes Kunth) IRRIGADA POR GOTEJAMENTO EM FUNÇÃO DE DIFERENTES NÍVEIS DE DEPLEÇÃO DE ÁGUA NO SOLO
}

\author{
ADRIANA RAMOS \\ Engenheira Agrônoma \\ Orientador: Prof. Dr. MARCOS VINÍCIUS FOLEGATTI \\ Dissertação apresentada à Escola Superior de \\ Agricultura "Luiz de Queiroz", Universidade de \\ São Paulo, para obtenção do título de Mestre \\ em Agronomia, Área de Concentração: \\ Irrigação e Drenagem.
}

PIRACICABA

Estado de São Paulo - Brasil

Abril - 1998 
Dados Internacionais de Catalogação na Publicação (CIP) DIVISĀO DE BIBLIOTECA E DOCUMENTAÇĀO - Campus "Luiz de Queiroz"/USP

\section{Ramos, Adriana}

Desenvolvimento vegetativo da pupunheira (Bactris gasipaes Kunth) irrigada por gotejamento em funçāo de diferentes niveis de depleção de água no solo / Adriana Ramos. - - Piracicaba, 1998.

$66 \mathrm{p}$.

Dissertação (mestrado) - Escola Superior de Agricultura Luiz de Queiroz, 1998. Bibliografia.

1. Balanço hidrico 2. Distribuição de água 3. Evapotranspiração 4. Irrigação por gotejamento 5. Palmeira 6. Planta cultivada 7. Solo 1. Título 


\section{À MINHA FAMÍLIA}

Aos meus pais Adauto Ramos e Roma Pereira do Nascimento, que nunca mediram esforços.

À minha irmã Eliane Ramos e meus sobrinhos Vinícius e Vítor Gomes da Penna, pelo amor e carinho.

Especialmente à Rosana Ramos, que foi durante muito tempo mais que irmã, uma mãe dedicada, que me ensinou muitas coisas

\section{OFEREÇO}

Á Alcester Mendes, pelo amor e respeito.

\section{DEDICO}




\section{AGRADECIMENTOS}

Ao Prof. Dr. Marcos Vinícius Folegatti, pela orientação, amizade e confiança depositada em minha pessoa, pela oportunidade de realização do curso.

À Dra. Marilene Alves Leão Bovi, pesquisadora do IAC, pelos ensinamentos e sugestões durante o transcorrer do trabalho.

Aos professores do Departamento de Engenharia Rural, pelos ensinamentos prestados.

À professora Maria Izalina Alves, pela orientação e ajuda nas análises estatísticas.

À CAPES, pela consessão da bolsa de estudos.

Aos colegas do curso de Mestrado, Carlos Amilton S. Santos, Luiz Fernando S. M. Campeche, Maurício Coelho Filho, Jarbas Honório de Miranda, Francisco Parise, em especial a Sebastião Figueredo.

Aos colegas do curso de pós-graduação Francisco Adriano Pereira e Sérgio Antônio Veronez de Souza, pelas sugestões apresentadas.

Ao Dr. Antônio Melhen Saad, do IPT, pelas sugestões referentes ao balanço hídrico.

Ao Engenheiro Agrônomo Lino Ricardo Rios Fúria, pelo material bibliográfico fornecido.

Aos funcionários do Departamento, César, Zezinho, Gilmar, Hélio, Antônio e Lino, pela amizade e apoio no desenvolvimento das atividades. 


\section{SUMÁRIO}

LISTA DE FIGURAS

Página

LISTA DE TABELAS

V1

RESUMO

V111

SUMMARY

$\mathrm{x}$

X11

1 INTRODUÇÃO

2 REVISÃO DE LITERATURA

2.1 Considerações Gerais sobre a Cultura

2.2 Análise do Crescimento da Cultura

2.3 Evapotranspiração

2.3.1 Balanço Hídrico

3 MATERIAL E METODOS

3.1.1 Caracterização da Área Experimental

3.1.1 Caracterização Física e Química do Solo

3.1.1.1 Análise Química do Solo

3.1.1.2 Curva de Retenção da Água no Solo

3.2 Instalação e Condução do Experimento

3.3 Tensiômetro

3.4 Lisímetro de Lençol Freático Constante

3.5 Manejo da Irrigação

3.6 Balanço Hidrico no Solo

3.6.1 Precipitação e Irrigação

3.6.2 Escoamento Superficial

3.6.3 Drenagem Profunda e Ascensão Capilar

3.6.4Variação no Armazenamento

3.6.5 Evapotranspiração

3.7 Avaliação do Desenvolvimento Vegetativo 23 
3.9 Análise Estatística 24

3.9.1 Análise Exploratória dos Dados 25

3.9.1.1 Histograma de Distribuição de Freqüência e Box-Plot 25

3.9.1.2 Teste de Homogeneidade de Variâncias 25

4 RESULTADOS E DISCUSSÕES 26

4.1 Análise Exploratória dos Dados 27

4.2 Análise de Variância e de Regressão 28

4.2.1 Variáveis Analisadas 28

4.2.1.1 Diâmetro no Colo $\quad 29$

4.2.1.2 Comprimento de Ráquis $\quad 34$

4.2.1.3 Altura 35

4.2.1.4 Número de Perfilhos 39

4.2.1.5 Número de Folhas $\quad 40$

4.2.1.6 Folhas Novas Emitidas 41

4.3 Desenvolvimento Vegetativo da Pupunha 45

4.4 Balanço Hídrico 46

4.4.1 Consumo de Água pela Cultura 51

5 CONCLUSÕES

ANEXOS 54

REFERÊNCIAS BIBLIOGRÁFICAS $\quad 59$ 


\section{LISTA DE FIGURAS}

Página

1. Curva de retenção da água no solo, na camada de 0 a 20 e de 20 a $40 \mathrm{~cm}$. em 14 Solo Terra Roxa Estruturada.

2. Vista parcial da área experimental. 16

3. Tensimetro digital de punção. 17

4. Temperatura, umidade relativa e precipitação pluviométrica para os meses de 26 realização das avaliações

5. Taxa de crescimento médio da variável diàmetro no colo $(\mathrm{cm} / \mathrm{dia})$, para os 30 diferentes tratamentos, para cada período e periodo total de avaliação.

6. Crescimento médio em diâmetro na região do colo em função dos períodos de 32 avaliação e dos tratamentos impostos, para os periodos irrigados.

7. Curvas e equações de regressão entre o diâmetro do colo e os periodos de 32 avaliação, para os períodos irrigados.

8. Crescimento médio em diàmetro na região do colo em função do periodo de 33 avaliação para todo período avaliado.

9. Curvas e equações de regressão entre o diâmetro do colo e o período de 34 avaliação, para todo período avaliado.

10. Crescimento médio da variável comprimento da ráquis em função do periodo 35 de avaliação, para todo periodo avaliado e equação de regressão.

11. Taxa de crescimento médio da variável altura $(\mathrm{cm} / \mathrm{dia})$, para os diferentes 36 tratamentos, para cada período e período total de avaliação.

12. Crescimento médio em altura em função dos períodos de avaliação e dos 37 tratamentos impostos, para os periodos irrigados.

13. Curvas e equações de regressão entre a altura e os períodos de avaliação, para 37 os periodos irrigados.

14. Crescimento médio em altura em função do periodo de avaliação para todo 38 período avaliado e equação de regressão. 
15. Curvas e equações de regressão entre a altura e o período de avaliação, para 38 todo periodo avaliado.

16. Número médio de perfilhos em função dos períodos de avaliação para todo 40 período avaliado.

17. Número médio de folhas em função do periodo de avaliação para todo 41 período avaliado.

18. Taxa de crescimento médio da variável folhas novas emitidas $(\mathrm{cm} / \mathrm{dia})$, para os diferentes tratamentos, para cada periodo e periodo total de avaliação.

19. Média do número de folhas novas emitidas em função dos períodos de avaliação e dos tratamentos impostos, para os períodos irrigados.

20. Curvas e equações de regressão entre o número médio de folhas emitidas e os periodos de avaliação, para os períodos irrigados.

21. Média do número de folhas novas emitidas em função do período de avaliação para todo período avaliado e equação de regressão.

22. Evapotranspiração média da cultura e de referència para cada período, para os Tratamentos 1, 2, 3 e 4 .

23. Variação do armazenamento de água (\%) em função da profundidade do solo $(\mathrm{cm})$.

24. Perfil de umidade do Tratamento 4 (Testemunha) no primeiro período de realização do balanço hídrico. 


\section{LISTA DE TABELAS}

Página

1. Análise granulométrica e densidade do solo da área experimental. 13

2. Análise química do solo da área experimental. 13

3. Potencial matricial e umidade volumétrica do solo observados e ajustados pela 14 curva de retenção para as profundidades de 10 e $30 \mathrm{~cm}$.

4. Teste $\mathrm{F}_{\text {maximo }}$ para todas as variáveis. 27

5. Análise de variância e teste $\mathrm{F}$ para as variáveis diâmetro na região do colo, 28 comprimento de ráquis e altura.

6. Análise de variância e teste $\mathrm{F}$ para as variáveis, número de perfilhos, número de folhas e emissão de folhas novas.

7. Médias originais de taxa de crescimento $(\mathrm{cm} / \mathrm{dia})$ da variável diâmetro na 30 região do colo $(\mathrm{cm})$ para o fator tratamento dentro do fator tempo.

8. Médias originais de taxa de crescimento ( $\mathrm{cm} / \mathrm{dia})$ da variável comprimento de 34 ráquis para o fator tratamento dentro do fator tempo.

9. Médias originais de taxa de crescimento $(\mathrm{cm} / \mathrm{dia})$ da variável altura para o fator 36 tratamento dentro do fator tempo.

10. Médias originais de taxa de crescimento $(\mathrm{cm} / \mathrm{dia})$ da variável número de 39 perfilhos para o fator tratamento dentro do fator tempo.

11. Médias originais de taxa de crescimento $(\mathrm{cm} / \mathrm{dia})$ da variável número de 40 folhas para o fator tratamento dentro do fator tempo.

12. Médias originais de taxa de crescimento $(\mathrm{cm} / \mathrm{dia})$ da variável emissão de novas para o fator tratamento dentro do fator tempo.

13. Componentes do balanço de água no solo, precipitação (P), irrigação (I), drenagem ou ascenção capilar (D/AC), variação de armazenamento ( $\Delta$ Arm.), evapotranspiração da cultura (ETc) e evapotranspiração de referência (Eto), realizado para o Tratamento 1 ( $25 \% \mathrm{AD})$.

14. Componentes do balanço de água no solo, precipitação (P), irrigação (I), drenagem ou ascenção capilar (D/AC), variação de armazenamento ( $\Delta$ Arm.), evapotranspiração da cultura (ETc) e evapotranspiração de referência (Eto), 
realizado para o Tratamento $2(50 \% \mathrm{AD})$.

15. Componentes do balanço de água no solo, precipitação (P), irrigação (I), drenagem ou ascenção capilar (D/AC), variação de armazenamento ( $\Delta$ Arm.), evapotranspiração da cultura (ETc) e evapotranspiração de referência (Eto), realizado para o Tratamento $3(75 \% \mathrm{AD})$.

16. Componentes do balanço de água no solo, precipitação (P), irrigação (I), drenagem ou ascenção capilar (D/AC), variação de armazenamento ( $\Delta$ Arm.), evapotranspiração da cultura (ETc) e evapotranspiração de referência (Eto), realizado para o Tratamento 4 (Testemunha).

17. Variação de armazenamento acumulado em função da profundidade do solo. 


\title{
DESENVOLVIMENTO VEGETATIVO DA PUPUNHEIRA (Bactris gasipaes Kunth) IRRIGADA POR GOTEJAMENTO EM FUNÇÃO DE DIFERENTES NÍVEIS DE DEPLEÇÃO DE ÁGUA NO SOLO
}

\author{
Autora: ADRIANA RAMOS \\ Orientador: Prof. Dr. MARCOS VINICIUS FOLEGATTI
}

\section{RESUMO}

O Brasil é o maior produtor, consumidor e exportador de palmito do mundo. Para atender esta alta demanda, a exploração predatória já provocou grande devastação das palmeiras nativas da Mata Atlântica. Para diminuir essa pressão de exploração surge a necessidade de plantio para a exploração permanente de palmito. Dentre as palmeiras que estão chamando a atenção dos agricultores, a pupunha (Bactris gasipaes Kunth) se destaca principalmente pelas suas características de precocidade e perfilhamento. Porém sua implantação em outra área que não seja seu habitat natural requer sua adaptação a este novo ambiente. Sendo assim, o presente trabalho tem como objetivos avaliar o efeito da aplicação de água no solo, em função da evapotranspiração de referência medida em um lisímetro de lençol freático constante, no crescimento e desenvolvimento vegetativo da pupunha e determinar a evapotranspiração da cultura pelo método do balanço hídrico de campo, submetida à irrigação por gotejamento. Este trabalho foi conduzido de 31/07/97 a 12//01/98, no campo experimental de Irrigação e Drenagem, da Fazenda Areão da Escola Superior de Agricultura "Luiz de Queiroz" - ESALQ/USP, localizada no município de Piracicaba - S.P. O delineamento empregado foi em blocos casualizados com parcelas subdivididas. Os tratamentos impostos corresponderam aos niveis de 0,25 , 50 e $75 \%$ de água disponivel e as avaliações do desenvolvimento vegetativo foram feitas 
pelas medidas de algumas variáveis de crescimento. O balanço hídrico foi realizado pela equação geral de conservação das massas. Como resultado do monitoramento de água no solo e avaliações de crescimento, para todas as variáveis, os maiores acréscimos ocorreram a partir dos 68 dias após o início da imposição dos tratamentos e avaliações; durante os meses de realização do balanço hídrico o valor de Kc médio para os períodos obtido foi de 0,91 e $80 \%$ da variação de armazenamento de água (consumo da cultura) ocorreu até a profundidade de $40 \mathrm{~cm}$, indicando que para as condições estudadas, a camada para manejo de irrigação deve ser de $0-40 \mathrm{~cm}$. 


\title{
DEVELOPMENT OF PALM PEACH (Bactris gasipaes Kunth) DRIP IRRGATED SUBMITTED TO DIFFERENT LEVELS OF SOIL MOISTURE
}

\author{
Author: ADRIANA RAMOS \\ Adviser: Prof. Dr. MARCOS VINÍCIUS FOLEGATTI
}

SUMMARY

Brazil is the largest producer, consumer and exporter of palm of the world. In order to satisfy this demand, the predatory exploration a great devastation of native palms of the Atlantic Forest has been done. An option to decrease this exploration is to incentive the production by the farmers permanently. Among the palms the palm peach (Bactris gasipaes Kunth) is getting a lot of interest by the farmers, because of its precocity and tillering, although its cultivation requires some time for an adaptation to the new environment. The objective of this work was to evaluate the effect of the different levels of water depth applied in function of the evapotranspiration rate measured by a lysimeter, over the development of palm peach and also estimate the evapotranspiration of the crop using a water balance method, under drip irrigation. This work was carried out during the period of $31 / 07 / 97$ to 12/01/98, at the irrigation experimental area of the Department of Rural Engineering, in Areão's Farm at University of São Paulo - ESALQ, Piracicaba - SP. The statistical analysis used was a randomized blocks split plot. The treatments were the $0,25.50$ and $75 \%$ of the water storage, and the of the development were to measure the vegetative variables of the crop like high, the length of the leaves, the numbers of tillering and the stem diameter. The crop coefficient during this period was 0,92 and the major soil water storage variation happened at the depth of $40 \mathrm{~cm}$. 


\section{INTRODUÇÃO}

O palmito, utilizado como alimento, é conhecido desde épocas remotas. Os índios foram os primeiros consumidores desse vegetal, pois já o empregavam em sua alimentação na época do descobrimento do Brasil. Atualmente, o palmito vem ocupando lugar de destaque, não só na cozinha brasileira, como na estrangeira.

No Brasil, várias palmeiras produzem palmito comestivel, porém, duas espécies predominam nesta atividade. Na região Centro-Sul a espécie nativa é a Euterpe edulis Mart., conhecida popularmente como palmiteiro juçara ou jiçara, fornecendo palmito de bom rendimento e boa qualidade, mas tem como desvantagem o fato de apresentar estipe único e não se regenerar após o corte. A espécie nativa do Norte do pais é a Euterpe oleracea Mart., conhecida popularmente como açaizeiro. Esta apresenta farto perfilhamento, porém fornece palmito de menor rendimento e baixa qualidade (Bovi, 1995).

Antes da década de 60, a produção básica de palmito vinha principalmente da costa meridional do país, sendo extraído da palmeira juçara. O estado de São Paulo era na época, o principal produtor. Porém, o ritmo da exploração sem correspondente replantio, fez cair rapidamente o número de palmeiras nessa região, ocasionando escassez de matéria-prima para as empresas processadoras do palmito que se transferiram para o estado do Pará, então com extensas reservas de açaizeiros (Renesto e Vieira, 1977).

De acordo com dados do IBGE, a produção anual de palmito é de cerca de 210.000 toneladas, $92 \%$ das quais obtidas somente no estado do Pará. Desta forma, o Brasil figura como o maior exportador de palmito, com uma participação de $70 \%$ do mercado em 1993 (CACEX, 1990) . 
Apesar da alta demanda, o palmito em conserva apresenta baixa qualidade devido, principalmente, a dificuldade de padronizar a matéria-prima dado o caráter extrativo dessa exploração. Acredita-se que o cultivo racional de outras palmeiras diminuiria sensivelmente a pressão de exploração sobre as espécies E. edulis e E. oleracea. Dentre as várias palmeiras passíveis de serem cultivadas para essa finalidade que vêm sendo pesquisadas, a pupunheira (Bactris gasipaes Kunth.) se destaca. principalmente devido às suas características de precocidade, rusticidade e perfilhamento. Características essas que faltam ao juçara, ou seja, o caráter permanente de exploração.

Durante as duas últimas décadas, a palmeira pupunha (Bactris gasipaes, Kunth) tem sido objeto de pesquisas intensivas e desenvolvimento em várias partes da América tropical (Clement, 1995). A Universidade da Costa Rica transformou-se, a partir dos anos 70, no principal centro de pesquisa existente no mundo sobre a palmeira pupunha; na Colômbia, o interesse data dos anos 50 , porém a pesquisa caminha com lentidão (Clement, 1987). No Brasil, o Instituto Agronômico de Campina (IAC) apresenta estudos sobre a palmeira pupunha que remotam do ano de 1950. A partir de 1976, quando a Divisão de Fruticultura do Instituto Nacional de Pesquisas da Amazônia (INPA) passou a considerar a espécie como prioridade, os estudos se expandiram com rapidez e ambos (IAC e INPA) colocaram o Brasil como segundo pólo gerador de informações sobre a palmeira. No entanto, há ausência de trabalhos sobre a influência da umidade no solo em cultivos de pupunha, e isto se deve ao fato de que a maioria das regiões produtoras de palmito possuem elevados índices pluviométricos. Porém, atualmente, a implantação de grandes áreas comerciais no estado de São Paulo, requer a adaptação desta cultura em seu novo ambiente, garantindo seu desenvolvimento e produtividade.

A precocidade é um grande estímulo ao cultivo da pupunheira, uma vez que a colheita inicial é por volta dos 18 meses, o que trará um retorno financeiro mais rápido. Tratando-se de uma cultura de alto valor econômico, a prática de irrigação poderá proporcionar um maior rendimento da produção em função da distribuição irregular das chuvas e pelo fato da cultura apresentar um sistema radicular bastante superficial. 
De acordo com Vieira (1989) a irrigação complementar compensa a irregularidade das chuvas, melhorando a qualidade dos produtos, em virtude da melhora do metabolismo vegetal.

Métodos distintos podem ser empregados na irrigação desta cultura, sendo que a escolha do método mais adequado deve estar associada às características da cultura, aos fatores climáticos e edáficos e à disponibilidade hídrica, entre outros.

Um método bastante eficiente é o de irrigação por gotejamento por permitir aplicação de água diretamente na zona radicular da cultura, apresentando a vantagem de perder menos água por evaporação e não sofrer a influencia do vento (Daker, 1988). O conhecimento da demanda hídrica durante os estádios fenológicos da cultura, bem como a movimentação da água no perfil do solo é de fundamental importância para que essa prática de irrigação se torne eficiente.

Em vista do exposto, os objetivos do presente trabalho foram:

a) avaliar o efeito da aplicação de diferentes níveis de depleção de água, tomando como critério básico os valores de evapotranspiração de referência, medidos em um lisímetro de lençol freático constante, no crescimento e desenvolvimento vegetativo da pupunheira;

b) determinar a evapotranspiração da cultura (ETc) de um plantio de pupunheira com três anos, pelo método do balanço hídrico de campo, submetida a irrigação por gotejamento. 


\section{REVISÄO DE LITERATURA}

\subsection{Considerações gerais sobre a pupunheira}

A pupunheira (Bactris gasipaes) é uma especie que vem sendo cultivada há vários anos por tribos indígenas das Américas do Sul e Central, tornando-se difícil determinar o lugar exato de sua origem (Camacho, 1976).

A distribuição geográfica desta espécie compreende territórios entre latitudes $16^{\circ}$ $\mathrm{N}$ e $17^{\circ} \mathrm{S}$ (Mora Urpi, 1984) desde o norte de Honduras até o sul da Bolívia e, do leste de São Luís do Maranhão à oeste do Rio das Esmeraldas no Equador (Barbosa, 1993).

A pupunheira é uma planta da família das Arecaceas, sendo uma palmeira multicaule, alógama, que em fase adulta pode alcançar 20 metros de altura. Seu tronco com 10 a 30 centímetros de diâmetro é monopodial e cilindrico. As folhas são pinadas, geralmente possuem espinhos no pecíolo e ráquis, e freqüentemente com espinhos nas nervuras e extremidades dos foliolos (Clement, 1995).

Estudo sobre o sistema radicular da cultura, realizado por Morales \& Vargas (1990), o apontam como superficial e expandido, já que a maior concentração das raizes da planta estudada se encontravam num raio e profundidade de $40 \mathrm{~cm}$, a partir do centro da planta. Já para Ferreira et al. (1996), o sistema radicular da pupunha é mais extenso e mais profundo, embora a maior biomassa radicular tenha sido encontrada dentro da área da projeção da copa, a maioria da área superficial absorvente foi encontrada fora desta área. Esses resultados variáveis podem ocorrer devido a diferenças no solo, manejo das plantas, metodologia de estudo e idade da planta.

A pupunheira é natural de áreas com precipitações entre 1500 e 6000 mm/ano. Melhores resultados são observados onde a precipitação está entre 2000 e 3000 mm/ano. 
Não só o índice de precipitação pluviométrica é importante, como também sua distribuição, pois a planta não tolera períodos secos maiores que três meses, ocasionando um atraso no desenvolvimento da planta para palmito e uma redução na frutificação (Villachica, 1996).

Segundo Bovi (1993), a pupunheira apresenta maior desenvolvimento vegetativo e maior peso em palmito por planta em regiões de clima quente e úmido, com temperatura média anual de $22^{\circ} \mathrm{C}$ e umidade relativa superior a $80 \%$. Sua ocupação dáse principalmente em áreas com altitudes inferiores a $900 \mathrm{~m}$.

A temperatura e a distribuição das chuvas determinam a taxa de crescimento, assim como a época de floração e frutificação.

A pupunheira é muito sensivel à deficiência de água, porém não tolera solos encharcados. Na Amazônia brasileira, essa espécie nativa é bem conhecida, sendo utilizada, há séculos, para a produção de frutos que são até hoje a base da alimentação dos habitantes de sua região de origem (Bovi, 1995). Clement (1987) afirma que a pupunheira é a única espécie da família Palmae que foi verdadeiramente domesticada pelos ameríndios, sobrevivendo à maioria desses povos.

A pupunheira perfilha, produzindo numerosos brotos basais que crescem rapidamente. É comum plantas com 5 anos de idade apresentando estipes com diâmetros e alturas iguais aos do principal. Segundo Bovi (1998), a produção do palmito nessa espécie é feita a partir dos 18 meses se for efetuada adubação apropriada e irrigação para suprir as necessidades hídricas da cultura, em regiões de baixa pluviosidade. As espécies tradicionais levam de 7 a 12 anos para o primeiro corte. Outra vantagem é o fato da pupunheira não apresentar escurecimento enzimático, pois, não apresenta em sua composição química as enzimas polifenol oxidase e peroxidase, um dos principais problemas no processamento do palmito de outras espécies de palmeira (Ferreira, 1982). Aliado a esses fatores, as plantas dessa espécie são bastante rústicas adaptando-se as diversas condições climáticas e tipos de solo (Bovi, 1995). Estudos sobre a palmeira pupunha no Estado de São Paulo, conduzidos pelo Instituto Agronômico de Campinas, afirmam que esta tem alta adaptabilidade às condições agroclimatológicas (Frerreira, 1982). 
A pupunheira que vem sendo plantada em larga escala no interior de São Paulo, é espécie de clima úmido. necessitando de chuvas anuais superiores a $1600 \mathrm{~mm}$ e bem distribuídas (Agrianual 1996). A precipitação média do estado de São Paulo é de 1360 mm por ano, deste total $1060 \mathrm{~mm}$ ocorrem na estação chuvosa e $285 \mathrm{~mm}$ na estação seca (Atlas Pluviométrico do Estado de São Paulo, 1972). Verifica-se irregularidade na distribuição das chuvas, além da possibilidade da ocorrência de veranicos. Portanto, a exigência de irrigação freqüente contornará esses problemas, uma vez que não comprometerá os processos físiológicos das plantas, não afetando seu desenvolvimento e sua produção.

\subsection{Análise do crescimento da cultura}

O desenvolvimento das culturas é o resultado da interação direta entre as características intrínsecas das plantas (genótipo) e as condições do meio ambiente (Arruda, 1989). O ambiente inclui aspectos climáticos e de solo, podendo ser manejados para aumentar a produção. O clima determina o nível da demanda atmosférica, e o solo, a disponibilidade de água às plantas (Sing et al., 1987).

Tomlinson $(1990)^{1}$, citado por Clement (1995), define cinco estádios de crescimento da palmeira: embrionário, plântula, estabelecimento, adulto vegetativo e reprodutivo. A fase embrionária se extende da fertilização do ovário à germinação do embrião, sendo a germinação definida como o final da dormência embrionária. A fase de plântula se extende da germinação para a diminuição das reservas nutritivas do endosperma. Como esta fase não pode ser observada morfologicamente, seu final é algo arbitrário. A fase de estabelecimento se extende da diminuição das reservas do endosperma para uma máxima expansão do diâmetro do estipe, sendo que o seu final claramente visível onde começa a ocorrer um elongamento da estirpe acima do nível do solo. A fase de adulto vegetativo se extende do início do alongamento do estipe (tronco) ao aparecimento da primeira inflorescência. A fase reprodutiva completa o ciclo de vida da palmeira, durante o qual a maior parte das palmeiras produzem regularmente órgãos

${ }^{1}$ TONLINSOM. P. B. The structural biology of palms. Oxford University Press, Oxford. UK. 1990. 
reprodutivos. O mesmo autor enfatiza que há variações consideráveis dentro da espécie para os padrões de crescimento durante todas as fases. Segundo Rognon (1972a, b), deve haver correlações entre os padrões de crescimento em uma fase e os padrões de crescimento em outra, como ocorre em còco (Cocos micifera L.).

Segundo Magalhães (1979), a análise de crescimento de planta consiste no método que descreve as condições morfo-fisiológicas da planta em diferentes intervalos de tempo, para se quantificar o desenvolvimento de um vegetal.

O crescimento de plantas, sob diferentes condições ambientais, pode ser realizado através de medidas de diversas maneiras: lineares, superficiais, peso e número de unidades estruturais. Entre as dimensões lineares, podemos citar a altura da planta; comprimento de ramificações, diâmetro de caules, entre outras. Para se ter uma visão mais precisa do crescimento de uma cobertura vegetal, a medida de altura é muito importante. O crescimento também pode ser acompanhado a partir de unidades estruturais morfológicas ou anatômicas, como ramificações, folhas, flores, frutos, raizes. Estas medidas podem fornecer informações importantes quanto à fenologia e são, muitas vezes, usadas para detectar diferenças entre os tratamentos estabelecidos (Benincasa, 1986).

A água destaca-se entre os fatores que afetam o desenvolvimento vegetativo por ser o meio de difusão dos solutos nas células e solvente para a maioria das reações bioquímicas; funciona ainda como regulador de temperatura, sendo básica na sustentação dos tecidos vegetais, dada a sua incompressibilidade.

Nas plantas em desenvolvimento há uma continuidade no fluxo da água desde o solo até a atmosfera. A absorção, a translocação e a transpiração da água pelas plantas dependem das condições climáticas e edáficas, bem como, de certas características fisiológicas próprias à planta. Falta ou excesso de água é freqüente fator de diminuição da produção.

Vizquez (1981) estudou o comportamento fenológico da cultura, pela determinação da morte e longevidade das folhas, época de maior produção, crescimento em altura e diâmetro do estipe em relação a precipitação mensal e total acumulada, número de dias chuvosos e número de dias secos mensais e totais acumulados. A análise 
estatística dos dados revelou correlações significativas entre os parâmetros avaliados e a precipitação, e por estes resultados obtidos. o autor ressalta a possibilidade de que a irrigação seja economicamente recomendada para o cultivo de pupunheira em regiões com baixos índices pluviométricos.

Nelliat (1968) estudou o efeito de diferentes freqüências de irrigação sobre o desenvolvimento vegetativo de plantas jovens de côco (Cocos micifera L.) em uma faixa de solo arenoso, ao longo da costa oeste da Índia. Ao final do terceiro ano de avaliação, houve diferença significativa no crescimento e vigor causados pelos diferentes tratamentos. Foi encontrado um aumento em altura e diâmetro de $164,84 \mathrm{~cm}$ e $30,72 \mathrm{~cm}$ respectivamente, com um número médio de 13,32 folhas produzidas para o tratamento com lâmina de 45 litros de água aplicados a cada quatro dias.

\subsection{Evapotranspiração}

De acordo com Daker (1988), as condições climáticas têm papel importante na evaporação do solo e na transpiração da planta, sendo a evapotranspiração, um elemento essencial na determinação da quantidade de água necessária à irrigação.

Segundo Doorembos \& Kassam (1979), a taxa de evapotranspiração expressa as necessidades hídricas da cultura, que variam com o seu estádio de desenvolvimento, o que torna sua estimativa essencial ao planejamento da irrigação, visando maior produtividade e manejo da disponibilidade dos recursos hídricos.

A comparação da evapotranspiração das culturas sob diferentes condições edafoclimáticas é feita através de coeficientes e/ou modelos agrometeorológicos.

Burman et al. (1980) consideram dois métodos de estimativa da evapotranspiração potencial: os de medida direta, constituido pelos lisímetros e balanço hídrico, e os indiretos que empregam equações empíricas e evaporímetros.

Qualquer um destes métodos possuı erros em suas estimativas de evapotranspiração. Para Villa Nova (1973), os lisímetros são mais precisos, pois as medidas podem ser feitas em intervalos horários, semanais, mensais e sazonais, dependendo do tipo de lisímetro utilizado, além de possibilitar medidas da 
evapotranspiração e drenagem profunda independentemente (Barrada, 1971).

Segundo Slatyer (1967), as vantagens do balanço hídrico quando comparado a medidas de fluxo de vapor d'água, é a facilidade de obtenção, processamento e interação dos dados obtidos no campo; as desvantagens são a baixa precisão relativa e as dificuldades de medida da evapotranspiração em períodos chuvosos.

Qualquer que seja o método empregado, a determinação da evapotranspiração da cultura é dificil, onerosa e sujeita a muitos erros, porém seu conhecimento torna-se essencial para manter o solo em condições ideais ao crescimento e desenvolvimento vegetativo.

\subsubsection{Balanço Hídrico}

Dentre os vários métodos de estimativa da perda total de água por uma superficie vegetada, o balanço hídrico apresenta uma melhor representatividade das condições de campo, pois utiliza um determinado volume de solo cultivado.

Segundo Reichardt (1985), o balanço hídrico é um método que define as condições hídricas sob as quais a cultura se desenvolve, através da avaliação dos processos de fluxo de água no solo, num dado intervalo de tempo.

$\mathrm{O}$ método do balanço hídrico num volume de controle de solo permite a determinação dos seus componentes (precipitação, irrigação, escoamento superficial, drenagem profunda, variação de armazenamento e evapotranspiração), por meio do emprego da equação geral de conservação de massa (Rose, (1966); Barrada, (1971); Luchiari Júnior, (1978); Reichardt et al., (1979): Costa, (1986); Sakai, (1989); Guandique, (1993)).

O volume de solo considerado delimita-se entre a superficie do solo e uma profundidade que compreenda, no mínimo, $80 \%$ do sistema radicular da cultura (Ometto, 1981). Portanto, o limite inferior depende da profundidade do sistema radicular da cultura em estudo.

A precipitação e irrigação representam os fluxos de entrada de água no volume de solo. A precipitação é o resultado final, já em retorno ao solo, do vapor d'água que se 
condensa na atmosfera, forma gotas de tamanho suficiente para quebrar a tensão e cair (Ometto, 1981). Deve ser medida através de pluviômetros e/ou pluviógrafos. Downey (1972) afirma que suas determinações originam erros que podem ser reduzidos em torno de 1 a $5 \%$ se técnicas corretas forem empregadas.

As quantidades de água que saem do solo são constituidas pela percolação ou drenagem profunda, evapotranspiração e escoamento superficial.

O escoamento superficial, dependendo da inclinação do terreno, pode somar-se às entradas ou às saídas de água, sendo medido através de técnicas apropriadas, mas devido às suas características de grandeza e volume, medidas diretas se tornam dificeis (Rose, 1966) e, sendo a superficie horizontal, pode ser considerado nulo ou desprezivel. Pereira et al. (1974) o considera nulo se a declividade do terreno for inferior a $3 \%$.

A drenagem profunda descreve a perda de água através do limite inferior do volume de solo, obtida mediante a equação de Buckinghan-Darcy. É a componente do balanço hídrico que apresenta as maiores dificuldades para determinação, muitas vezes negligenciada ou incluída como parte do armazenamento de água ou evapotranspiração da cultura (Rose, 1966), sendo em certas condições responsável por erros de 30\% a 50\% do balanço hídrico total (Reichardt et al., 1974; Pereira et al., 1974).

Segundo Downey (1971) e Kalma \& Stanhill (1969), muitos pesquisadores têm ignorado a drenagem profunda, podendo com isto acrescentar em torno de $15 \%$ a $20 \%$ ao total de água aplicada à cultura. Reichardt et al. (1979) afirmam que podem ocorrer erros na estimativa do gradiente de potencial hidráulico no solo, principalmente na determinação da condutividade hidráulica.

Segundo Jensen (1967), outra fonte de erro é o intervalo de tempo considerado para o balanço, constatando que períodos que variam de 3 a 5 dias podem ocasionar erros de $15 \%$ a $30 \%$ na estimativa da evapotranspiração. Costa (1986) observou que em períodos chuvosos podem ocorrer limitações na medida diária da evapotranspiração devido à difículdade na determinação da variação na lâmina de água armazenada no solo com precisão maior que $2 \mathrm{~mm}$ de água.

O armazenamento da água no solo é dado através da integração de perfis consecutivos de umidade do solo em determinado intervalo de tempo. O saldo de água 
no solo é dado pela variação de água armazenada no perfil de solo definido. Se a quantidade de água que entra, no período, for maior do que a saída, o saldo será positivo e, do contrário, negativo (Libardi, 1995). Existem várias técnicas para medir a umidade no perfil considerado, como a gravimétrica, a de sonda de neutrons e a de tensiòmetros. Também existem erros envolvidos na sua determinação como os apontados por Downey (1972), estimados em torno de $10 \%$. 


\section{MATERIAL E MÉTODOS}

\subsection{Caracterização da Área Experimental}

O estudo foi desenvolvido no campo experimental de Irrigação e Drenagem, do Departamento de Engenharia Rural, na Fazenda Areão da Escola Superior de Agricultura "Luiz de Queiroz" - ESALQ/USP, localizada no município de Piracicaba S.P., a uma altitude de 576 metros e coordenadas geográficas de $22^{\circ} 42^{\prime} 30^{\prime \prime}$ de latitude sul e $47^{\circ} 30^{\prime} 00^{\prime \prime}$ de longitude oeste.

Segundo a classificação climática de Köppen, o clima é do tipo CWA, isto é subtropical úmido, verão chuvoso, e inverno seco. A precipitação média anual é 1247 $\mathrm{mm}$, temperatura média $21,1^{\circ} \mathrm{C}$, umidade relativa média de $74 \%$ e velocidade do vento de $2,2 \mathrm{~m} / \mathrm{s}$ com direção E/SE predominantemente (média de 71 anos; 1917 a 1987) (Ometto, 1991).

O solo classifica-se como Terra Roxa Estruturada (Alfisol), serie Luiz de Queiroz, apresentando declividade média de $2,3 \%$. As Tabelas 1 e 2 apresentam, respectivamente, as características fisicas e químicas do solo.

\subsubsection{Caracterização Física e Química do Solo}

Para a determinação dos principais parâmetros do solo da área experimental foi escavada uma trincheira $(1 \times 1 \times 1 \mathrm{~m})$ ao lado da parcela experimental, onde foram retiradas amostras de solo com estrutura deformada e indeformada (através de anéis volumétricos com diâmetro médio de $4,9 \mathrm{~mm}$ e altura média de $2,8 \mathrm{~mm}$ ), nas profundidades de 0-20, 20-40, 40-60 e 60-80 cm, para a determinação das características 
fisico-hídricas.

\subsubsection{Análise Química do Solo}

Para determinação das características quimicas, foram coletadas amostras de solo dentro da parcela experimental, nas profundidades de 0-20 e 20-40 cm cuja posterior análise foi feita em laboratório. Os resultados obtidos encontram-se nas Tabelas 1 e 2.

Tabela 1 - Análise granulométrica e densidade do solo da área experimental.

\begin{tabular}{ccccc}
\hline $\begin{array}{c}\text { Profundidade } \\
\mathbf{( c m )}\end{array}$ & $\begin{array}{c}\text { Argila } \\
\mathbf{( \% )}\end{array}$ & $\begin{array}{c}\text { Silte } \\
\mathbf{( \% )}\end{array}$ & $\begin{array}{c}\text { Areia } \\
\mathbf{( \% )}\end{array}$ & $\begin{array}{c}\text { Densidade do Solo } \\
\left(\mathbf{g . c m}^{-3}\right)\end{array}$ \\
\hline $0-20$ & 40,87 & 27,64 & 31,49 & 1,39 \\
$20-40$ & 47,62 & 23,16 & 29,23 & 1,34 \\
$40-60$ & 50,30 & 23,53 & 26,17 & 1,35 \\
$60-80$ & 52,85 & 34,38 & 23,98 & 1,23 \\
\hline
\end{tabular}

Tabela 2 - Análise química do solo da área experimental.

\begin{tabular}{|c|c|c|c|c|c|c|c|c|c|c|c|c|}
\hline $\begin{array}{l}\text { Prof. } \\
\text { (cm) }\end{array}$ & $\begin{array}{c}\mathrm{pH} \\
\mathrm{CaCl} 2\end{array}$ & $\begin{array}{c}\text { M.O. } \\
(\%)\end{array}$ & $\mathbf{P}$ & $\begin{array}{l}\text { S-SO4 } \\
\text { ppm }\end{array}$ & K & Ca & $\mathrm{Mg}_{\mathrm{n}}$ & $\begin{array}{l}\mathrm{Al} \\
\mathrm{eq} / 1\end{array}$ & $\begin{array}{l}\mathrm{H}+\mathrm{Al} \\
0 \mathrm{~g}\end{array}$ & SB & $T$ & $\begin{array}{c}\mathrm{V} \\
(\%)\end{array}$ \\
\hline $0-20$ & 4,4 & 2,4 & 21 & 4,6 & 0,28 & 0,5 & 0,26 & 0,3 & 0,58 & 7,9 & 13,7 & 58 \\
\hline $20-40$ & 5,0 & 2,4 & 15 & 4,2 & 0,3 & 0.3 & 0,11 & 0 & 0,47 & 4,7 & 9,4 & 50 \\
\hline
\end{tabular}

\subsubsection{Curva de Retenção da Água no Solo}

Um dos parâmetros básicos para o estudo da dinâmica da água no solo, foi a determinação da curva de retenção de água, para as diversas camadas do solo. Os pontos da curva foram determinados em Laboratório de Solos, em mesa de tensão, para as tensões de $0,1,2$ e $4 \mathrm{Kpa}$, abrangendo assim as faixas de umidade próximas da saturação, e na Câmara de Pressão de Richards, para as tensões de 10, 30, 50, 100, 500 e $1500 \mathrm{Kpa}$.

A partir dos dados da curva de retenção, optou-se pelo uso da equação proposta por Van Genuchten (1980) para obtenção de um melhor ajuste dos dados de potencial matricial e umidade volumétrica do solo. A Tabela 3 apresenta os valores de umidade volumétrica do solo observados e ajustados, para as profundidades de 10 e $30 \mathrm{~cm}$. 
Tabela 3 - Potencial matricial e umidade volumétrica do solo observados e ajustados pela curva de retenção para as profundidades de 10 e $30 \mathrm{~cm}$.

\begin{tabular}{|c|c|c|c|c|}
\hline \multirow[t]{2}{*}{$\begin{array}{c}\text { Potencial Matricial } \\
(\mathrm{KPa})\end{array}$} & \multicolumn{2}{|c|}{$\begin{array}{c}\text { Umidade (10cm) } \\
\left(\mathrm{cm}^{3} / \mathrm{cm}^{3}\right)\end{array}$} & \multicolumn{2}{|c|}{$\begin{array}{c}\text { Umidade (30cm) } \\
\left(\mathrm{cm}^{3} / \mathrm{cm}^{3}\right)\end{array}$} \\
\hline & Observada & Ajustada & Observada & Ajustada \\
\hline 0 & 0,5410 & 0,5420 & 0,5420 & 0,5253 \\
\hline 1 & 0,4583 & 0,4538 & 0,4865 & 0,4840 \\
\hline 2 & 0,4143 & 0,4213 & 0,4613 & 0,4567 \\
\hline 4 & 0,4032 & 0,3972 & 0,4530 & 0,4489 \\
\hline 10 & 0,3671 & 0,3692 & 0,4259 & 0,4260 \\
\hline 30 & 0,3426 & 0,3430 & 0,4009 & 0,4012 \\
\hline 50 & 0,3344 & 0,3330 & 0,3882 & 0,3908 \\
\hline 100 & 0,3230 & 0,3213 & 0,3788 & 0,3781 \\
\hline 500 & 0,3018 & 0,3008 & 0,3543 & 0,3536 \\
\hline 1500 & 0,2911 & 0,2909 & 0,3401 & 0,3403 \\
\hline
\end{tabular}

Na Figura 1 são apresentadas as curvas de retenção de água no solo para as profundidades de 10 e $30 \mathrm{~cm}$, respectivamente.

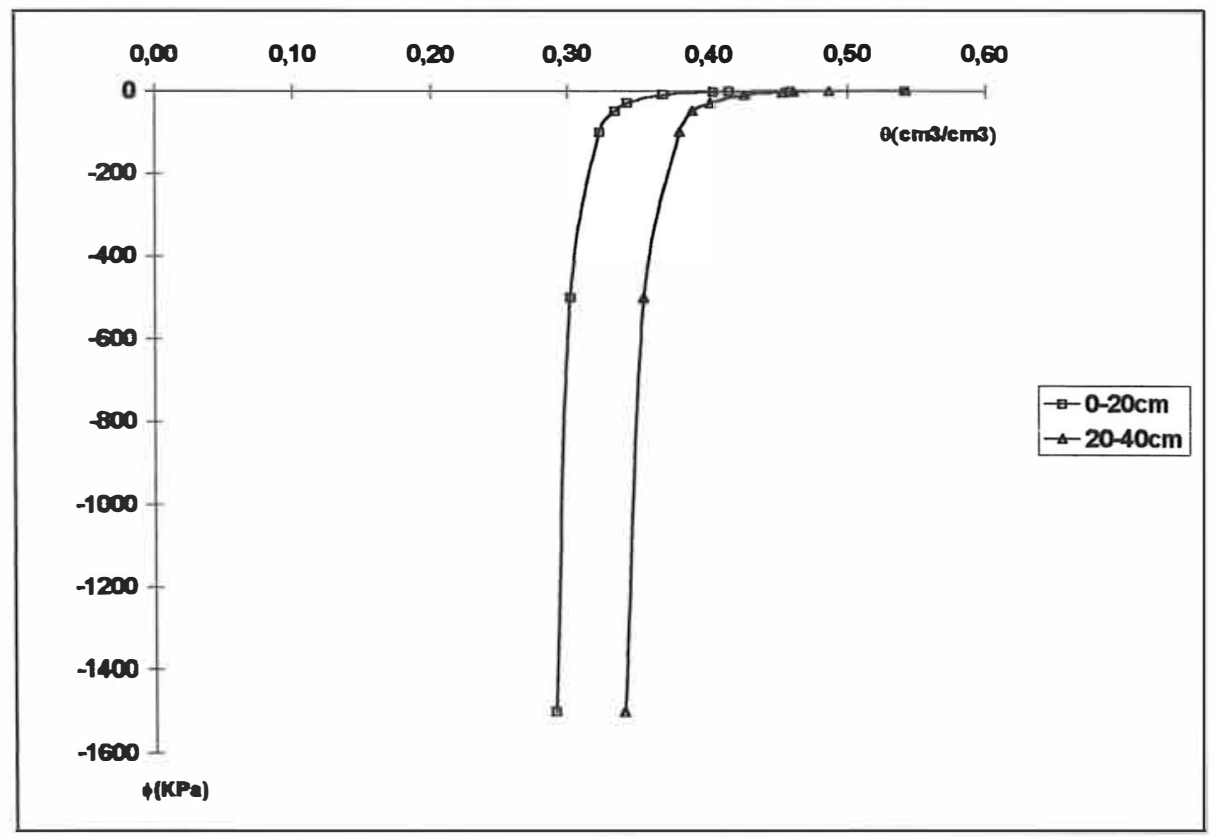

Figura 1 - Curva de retenção de água no solo, na camada de 0 a 20 e de 20 a $40 \mathrm{~cm}$, em Solo Terra Roxa Estruturada. 


\subsection{Instalação e Condução do Experimento}

$\mathrm{Na}$ área experimental (Figura 2) encontra-se instalado um plantio de pupunheira, com três anos de idade, com plantas espaçadas de $2 \times 1 \mathrm{~m}$, num total de trezentas plantas, numa área de $12 \mathrm{~m} \times 50 \mathrm{~m}$.

O delineamento experimental empregado foi em blocos casualizados com parcelas subdivididas, com quatro tratamentos e oito repetiçōes. Os tratamentos correspondem a quatro níveis de irrigação, baseados nas porcentagens de $25 \%$ (Tratamento 1), 50\% (Tratamento 2) e 75\% (Tratamento 3) de água disponível consumida em função da evapotranspiração de referência medida em um lisímetro de lençol freático constante, mais a testemunha (Tratamento 4).

Cada parcela apresenta as dimensões de oito metros de largura por quatro metros de comprimento, totalizando uma área de $32 \mathrm{~m}^{2}$, com dezesseis plantas por parcela. Foram instalados tensiômetros nas parcelas, nas profundidades de 10, 30, 50 e $70 \mathrm{~cm}$, para obtenção das informações do potencial mátrico e do gradiente de potencial total da água no solo.

\subsection{Tensiômetro}

O tensiômetro utilizado nesse estudo foi o tensímetro digital de punção. Utilizouse de um tensiômetro construído a partir de um tubo de PVC rígido, com diâmetro de 21 $\mathrm{mm}$ externo e $15 \mathrm{~mm}$ interno, cápsula de cerâmica porosa, com $6 \mathrm{~mm}$ de comprimento e diâmetro equivalente ao do $\mathrm{PVC}$, com um tubo de plástico transparente de seção curta na parte superior, e uma borracha para vedação deste tubo. A pressão do ar na parte superior final do tubo plástico transparente é medida pela inserção de uma agulha através da borracha, fixada a um transdutor de pressão (Marthaler et al., 1983) (Figura 3). 


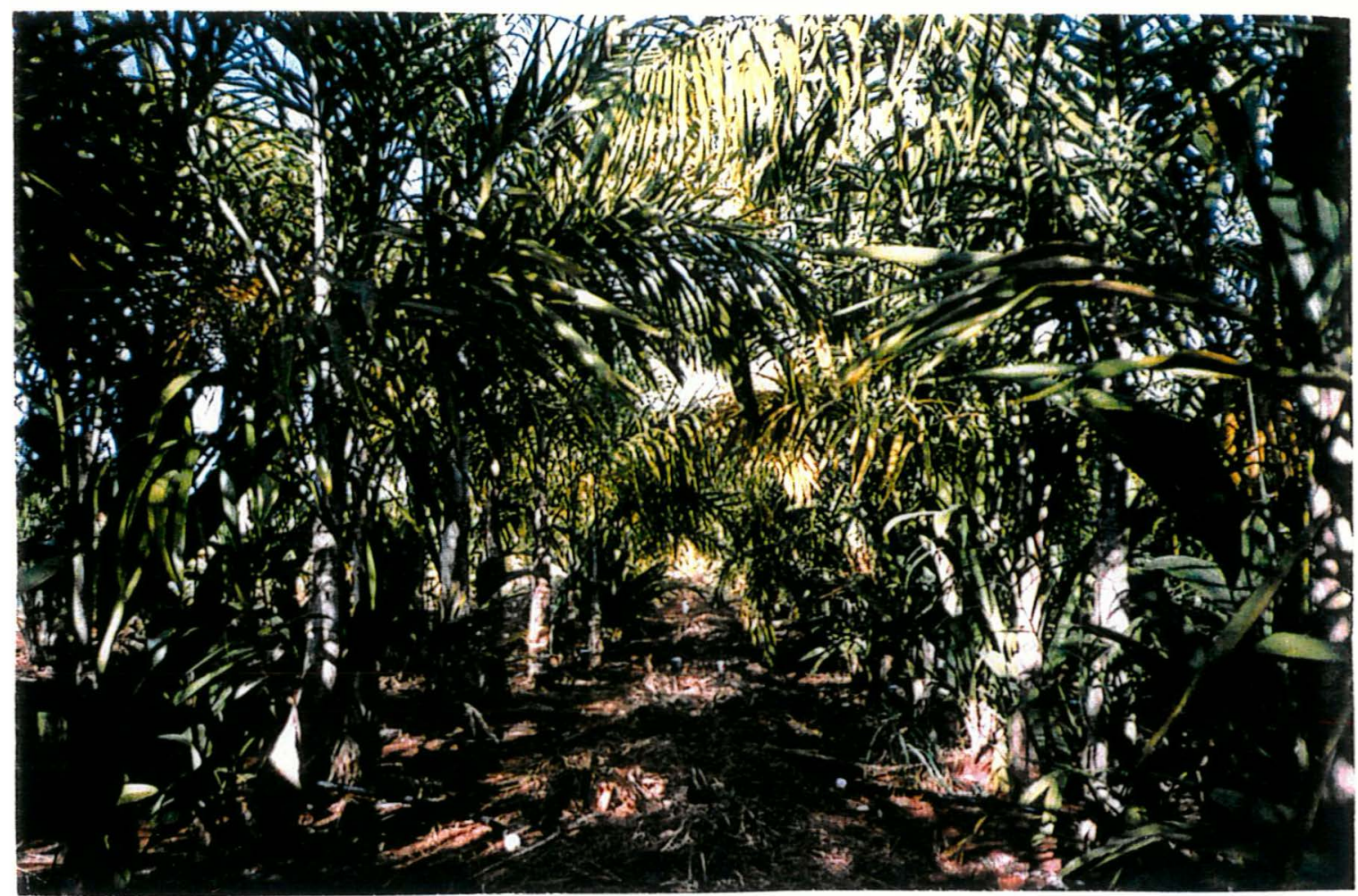

Figura 2 - Vista parcial da área experimental.

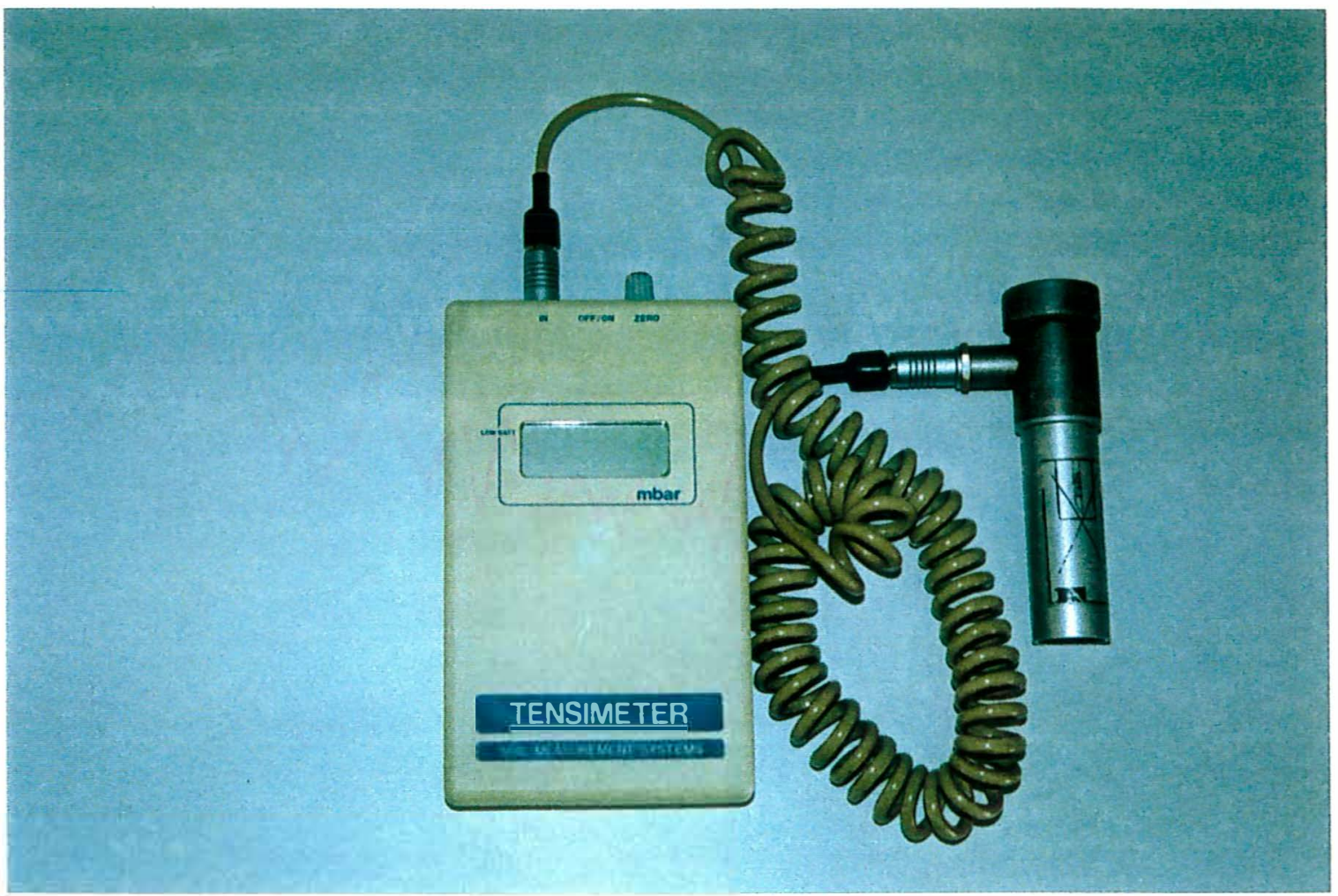

Figura 3 - Tensímetro digital de punção. 


\subsection{Lisímetro de Lençol Freático Constante}

O par de lisímetros utilizado. consta de tanques enterrados $(1,20 \times 0,85 \times 0,65 \mathrm{~m})$ com uma área exposta evaporante de $0,92 \mathrm{~m}^{2}$, devido ao formato da borda irregular. Cada tanque está acoplado a um reservatório intermediário $(0,30 \times 0,30 \times 0,25 \mathrm{~m})$ através de um tubo de PVC de $32 \mathrm{~mm}$ de diâmetro, sendo que este reservatório é composto por um sistema de bóia e regulagem de nível, sendo ligado ao reservatório de alimentação $(0,30 \mathrm{~m}$ de diâmetro x 0,65 $\mathrm{m}$ de altura). As ligações entre os reservatórios e a saída da tubulação são feitas por uma mangueira não transparente, flexível, de 13 mm de diâmetro. Os reservatórios intermediários e de alimentação encontram-se protegidos em um abrigo.

O funcionamento e manejo do lisímetro estão descritos em Silva (1996).

\subsection{Manejo da Irrigação}

Para aplicação de água, empregou-se um sistema de irrigação localizada, tipo gotejamento, com seis linhas laterais espaçadas entre si de $2 \mathrm{~m}$. Os gotejadores inseridos na linha lateral, apresentam uma vazão de 1,7 litros por hora com pressão de serviço de $120 \mathrm{KPa}$ com três emissores por planta. O cálculo do Coeficiente de Uniformidade do sistema foi realizado para avaliação da distribuição de água ao longo da linha, segundo metodologia proposta por Keller e Karmeli (1974).

A partir da curva de retenção (Figura 1), calculou-se a lâmina inicial de irrigação pela capacidade máxima de armazenamento da água no solo, colocando o solo em capacidade de campo até a profundidade de $80 \mathrm{~cm}$. Para as demais irrigações utilizou-se os valores de capacidade de campo e ponto de murcha permanente até a profundidade de $40 \mathrm{~cm}$, por ser este o volume de controle da água no solo. As irrigações foram realizadas

quando 25,50 e $75 \%$ da água disponivel foi consumida, definindo os Tratamentos 1, 2 e 3 respectivamente. 
O cálculo da lâmina de irrigação foi realizado por meio da utilização da seguinte equação:

$$
\mathrm{h}=(\theta \mathrm{cc}-\theta \mathrm{pmp}) \cdot \mathrm{z} \cdot \mathrm{y}
$$

em que:

$\theta \mathrm{cc}$ - umidade do solo em capacidade de campo $\left(\mathrm{cm}^{3} / \mathrm{cm}^{3}\right)$, obtida pela curva de retenção na profundidade de $80 \mathrm{~cm}$, correspondente a tensão de $10 \mathrm{KPa}$.

Өpmp - umidade do solo no ponto de murcha permanente $\left(\mathrm{cm}^{3} / \mathrm{cm}^{3}\right)$, obtido pela curva de retenção na profundidade de $80 \mathrm{~cm}$, correspondente a tensão de $1500 \mathrm{KPa}$. $\mathrm{z}$ - profundidade considerada $(\mathrm{cm})$.

y $-\%$ de água disponível.

A lâmina de irrigação total foi definida pela seguinte equação:

$$
h t=\frac{h}{E a}
$$

em que:

Ea é a eficiência de aplicação de água .

Considerou-se o valor de $90 \%$ para a eficiência de aplicação do sistema de irrigação, pois em irrigação por gotejamento seu valor varia em torno de $90 \%$.

O controle da irrigação baseou-se na metodologia recomendada pela FAO (Doorembos e Kassan, 1979), em que a evapotranspiração máxima da cultura ( $\mathrm{mm} / \mathrm{dia})$ é determinada pela equação:

$$
\mathrm{ETm}=\mathrm{ETo} \cdot \mathrm{kc}
$$


em que:

ETm - Evapotranspiração máxima de uma cultura. sem restrição hídrica no solo, desenvolvendo-se em grandes áreas e em condições ótimas de fitossanidade;

Kc - coeficiente de cultura, seu valor depende da fase de desenvolvimento da cultura;

ETo - Evapotranspiração de uma superficie extensa coberta com grama batatais (Paspalum notatum), com 8 a $15 \mathrm{~cm}$ de altura, em pleno desenvolvimento vegetativo, cobrindo totalmente o terreno e sem restrições hídricas no solo.

Utilizou-se o valor médio diário da evapotranspiração potencial de referência obtida por dois lisímetro de lençol freático constante. multiplicando-se por um Kc médio igual a 0,85 obtido por Rao (1980), para a cultura do côco (Cocos micifera L.), com cinco anos, onde as taxas de evapotranspiração da cultura foram quantificadas a partir da variação de umidade do solo por gravimetria e medidas lisimétricas.

\subsection{Balanço Hídrico}

A determinação da evapotranspiração da cultura resulta do balanço hídrico aplicado a um volume de solo explorado pelas raizes das plantas. Admite-se que esse volume de controle representa adequadamente a área da cultura. Pelas características da cultura, foi considerado um volume de solo de profundidade $40 \mathrm{~cm}$, no qual foram realizados as diversas determinações dos componentes do balanço hídrico.

Instalou-se os tensiômetro nas profundidades de 10 e $30 \mathrm{~cm}$, supondo que os mesmos messam os potenciais matriciais que correspondem às umidades "médias" das camadas de 0 - $20 \mathrm{~cm}$ e 20 - $40 \mathrm{~cm}$. Para efeito de cálculo da drenagem profunda, a profundidade de medida do gradiente de potencial total foi de $40 \mathrm{~cm}$, medido pelos tensiômetros a 30 e $50 \mathrm{~cm}$.

Pela lei de conservação das massas, demonstra-se que a soma algébrica das densidades de fluxos, é igual às variações da quantidade de água armazenada, em um determinado volume de solo num, dado intervalo de tempo. 


$$
\mathrm{P}+\mathrm{I} \pm \mathrm{Es}-\mathrm{Etc} \pm \mathrm{Qz}=\Delta \mathrm{A}_{\mathrm{L}}
$$

em que :

P - precipitação, mm;

I - ırrıgação, mm;

Es - escoamento superficial, $\mathrm{mm}$;

Etc - evapotranspiração da cultura, mm;

Qz - drenagem profunda (-) ou ascensão capilar (+), mm;

$\Delta \mathrm{A}_{\mathrm{L}}$ - variação do armazenamento de água no volume de controle do solo, $\mathrm{mm}$.

\subsubsection{Precipitação}

A precipitação foi obtida por um pluviômetro da estação meteorológica automática, já calibrado para a unidade em milímetros.

\subsubsection{Escoamento Superficial}

Considerou- se nulo o escoamento superficial uma vez que a declividade do solo está em torno de $3 \%$.

\subsubsection{Drenagem Profunda e Ascensão Capilar}

Os componentes de drenagem profunda e ascensão capilar, no limite inferior do volume de controle do solo, e nos tempos considerados, foram estimados pela equação de Darcy-Buckingham, modificada por Richards (1928)

$$
\mathrm{q}=-\mathrm{K}(\theta) \cdot \nabla \phi \mathrm{t}
$$


em que:

q - densidade de fluxo de drenagem ou ascensão capilar, mm.dia ${ }^{-1}$;

$\mathrm{K}(\theta)$ - condutividade hidráulica, $\mathrm{mm} \cdot \mathrm{dia}^{-1}$;

$\nabla \phi \mathrm{t}$ - gradiente de potencial total, $\mathrm{cm} . \mathrm{cm}^{-1}$;

$\theta \quad$ - umidade volumétrica $\mathrm{cm}^{3} \cdot \mathrm{cm}^{-3}$.

Como só foram considerados os fluxos na direção vertical até a profundidade de $40 \mathrm{~cm}$, a equação (5) se simplifica para:

$$
Q z=-\left[K(\theta) \frac{\partial H}{\partial Z}\right] \cdot k
$$

em que:

Qz - drenagem ou ascensão capilar, mm.dia ${ }^{-1}$;

$\mathrm{K}(\theta)$ - condutividade hidráulica, $\mathrm{mm} \cdot \mathrm{dia}^{-1}$;

$\frac{\partial H}{\partial Z}$ - gradiente de potencial total na profundidade considerada;

k - vetor unitário na direção vertical.

A condutividade hidráulica não saturada foi determinada por Costa (1986), para a profundidade de $40 \mathrm{~cm}$, em Terra Roxa Estruturada, segundo metodologia proposta por Libardi et al (1980), cuja equação é a seguinte:

$$
K(\theta)=K o \cdot e^{\left.: !^{: \theta-\theta 0}\right)}
$$

em que:

$\mathrm{K}(\theta)$ - condutividade hidráulica, mm.dia ${ }^{-1}$;

Ko - condutividade hidráulica saturada, mm.dia ${ }^{-1}$;

$\gamma \quad$ - parâmetro de ajuste admensional;

$\theta$ - umidade volumétrica atual, $\mathrm{cm}^{3} \cdot \mathrm{cm}^{-3}$;

Өo - umidade volumétrica de saturação, $\mathrm{cm}^{3} \cdot \mathrm{cm}^{-3}$. 


\subsubsection{Variação no Armazenamento}

A variação de armazenamento da água no perfil de solo estudado, foi obtida através da diferença de armazenamento entre o último e o primeiro dia do período considerado. Os valores de umidade volumétrica do perfil de solo foram obtidos através das leituras dos tensiômetros, convertidos em umidade pela equação de ajuste da curva de retenção de água.

\subsubsection{Evapotranspiração}

A evapotranspiração foi determinada por diferença, utilizando a equação (4), simplificada para o balanço hídrico, tendo em vista que os outros componentes foram determinados mediante a metodologia descrita anteriormente.

$$
\mathrm{Etc}=\mathrm{P}+\mathrm{I} \pm \mathrm{i} \mathrm{z}-\Delta \mathrm{A}_{\mathrm{L}}
$$

em que :

Etc - evapotranspiração da cultura, mm;

P - precipitação, mm;

I - 1rrigação, mm;

Es - escoamento superficial, $\mathrm{mm}$;

Qz - drenagem profunda (-) ou ascensão capilar (+), mm;

$\Delta \mathrm{A}_{\mathrm{L}}$ - variação do armazenamento de água no volume de controle do solo, $\mathrm{mm}$. 


\subsection{Avaliação do Desenvolvimento Vegetativo}

A avaliação dos tratamentos foi realizada através de avaliações no desenvolvimento da cultura, onde todas as plantas de cada bloco foram mensuradas, considerando-se as seguintes características:

a) diâmetro do estipe na região do colo;

b) altura da planta: foi medida da base do tronco ao ponto de inserção da folha mais nova;

c) comprimento da ráquis: foi medido a partir do ponto de inserção do primeiro folíolo à extremidade apical da ráquis;

d) número de perfilhos por planta;

e) número de folhas: contagem do número de folhas vivas abertas, pois as folhas amarelas foram ignoradas, assumindo serem fotossintéticamente inativas;

f) emissão de folhas novas: para identificação das folhas novas emitidas pela planta foram amarradas fitas às mesmas.

Assim que se iniciaram as irrigações mediu-se todas as plantas (31/07/97), sendo que as próximas avaliações foram realizadas aos 34 (04/09/97), 68 (08/10/97), 83 (23/10/97) e 98 dias (07/11/97). Ao término dos 98 dias, as irrigações foram suspensas em função de chuvas intensas que ocorreram no mês de novembro, e foram realizadas mais duas avaliações aos 133 (12/12/97) e aos 168 dias (16/01/98).

Os valores de crescimento das variáveis medidas foram determinados pelas taxas de crescimento que ocorreram entre as avaliações. A taxa de crescimento é representada pela variação, ou incremento entre duas avaliações. Assim, foi calculada da seguinte maneira:

$$
\mathrm{Tc}=\mathrm{A}_{2}-\mathrm{A}_{1} / \mathrm{T}_{2}-\mathrm{T}_{1}
$$


em que:

$A_{1}$ e $A_{2}$ - valores reais mensurados;

$\mathrm{T}_{1}$ e $\mathrm{T}_{2}$ - periodo (tempo) em que foram realizadas as avaliações.

Pelo fato da cultura apresentar melhor desenvolvimento vegetativo sob determinadas condições meteorológicas, foram usados sensores de temperatura e umidade relativa do ar, para verificar as influências do ambiente sobre o desenvolvimento da cultura, os quais foram conectados a um sistema de aquisição de dados, obtidos de uma estação meteorológica automática próxima à área irrigada, estando vegetada sobre grama batatais (Paspalum notatum). Esses dados encontram-se na Figura 4.

\subsection{Tratos Culturais}

As adubações foram realizadas em função da análise quimica (Tabela 2) onde foram aplicadas $28 \mathrm{~g} /$ planta da formulação de mercado 20:05:10 e complementada com $10 \mathrm{~g}$ de uréia por planta, em cada cobertura, realizadas mensalmente. Para manter a cultura no limpo evitando a competição com as ervas daninhas, as mesmas foram roçadas.

\subsection{Análise Estatística}

Para a análise estatística realizaram-se análises de variância e de regressão e testes de significância para os tratamentos e tempos de avaliação, para todas as variáveis. Utilizou-se para este procedimento o Sanest - Sistema de Análise Estatistica para o delineamento em blocos ao acaso com parcelas subdivididas no tempo. 
Foram utilizados quatro tratamentos referentes aos niveis de depleção de água no solo $(0,25,50$ e $75 \%$ A.D.) aplicados em oito blocos, obtendo-se assim, 32 observações, realizadas em quatro períodos distintos (aos 34,68, 83 e 98 dias após a imposição dos tratamentos).

\subsubsection{Análise Exploratória dos Dados}

Inicialmente, realizou-se a análise exploratória dos dados para verificação das seguintes pressuposições: estudo de homogeneidade de variâncias, independência entre os erros e erros com distribuição normal. Utilizou-se, para isto, de histograma de frequência e box-plot, teste de homogeneidade de variância e diagram de dispersão.

\subsubsection{Histograma de Distribuição de Freqüência e Box-plot}

Os histogramas de distribuição de frequeência foram feitos para analisar as características de simetria e distribuição, entre outras, de cada grupo de dados (variáveis). Já o box-plot mostra ainda a dispersão dos "outliers" (dados discrepantes) e sua localização espacial.

\subsubsection{Teste de Homogeneidade de Variâncias}

Verificou-se pelo teste $F_{\text {maximo }}$, se a relação entre a maior e a menor variância indicava heterogeneidade de variâncias.

$$
F_{\text {max }}=S_{\text {mix }}^{2} / S_{\text {min }}^{2} \sim F_{(k \text { trat; } v-1)}
$$

em que:

k - número de tratamentos;

v-1 - grau de liberdade.

Se o F calculado for maior que o tabelado rejeita-se a hipótese de que as variâncias de tratamentos são homogêneas. Assim, deve-se verificar se essa heterogeneidade pode ou não ser eliminada com a transformação dos dados. 


\section{RESULTADOS E DISCUSSÃO}

As irrigações foram realizadas quando 25, 50 e 75\% da água disponível foi consumida, em função da evapotranspiração de referência, medida por um lisímetro de lençol freático constante, multiplicada por um Kc do côco (Cocos mucifera) de 0,85 obtido por Rao (1980). No mês de agosto, em que a temperatura média mensal foi de $19^{\circ} \mathrm{C}$ (Figura 4), a freqüência de irrigação foi menor, porém, com o aumento da temperatura nos meses seguintes, a freqüência aumentou e o fornecimento de água foi mais intenso, com turnos de rega correspondentes a cada tratamento de 2, 4 e 6 dias aproximadamente.

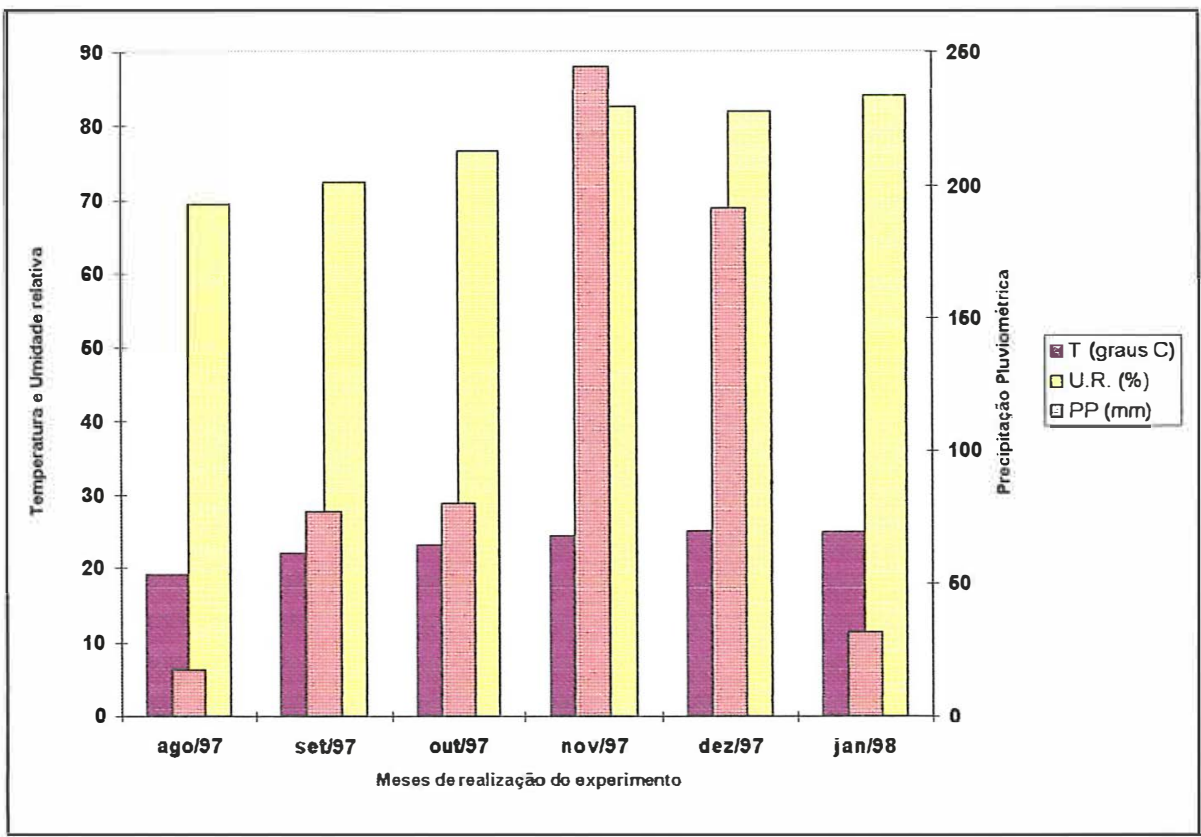

Figura 4 - Temperatura, umidade relativa e precipitação pluviométrica para os meses de realização do experimento. 


\subsection{Análise Exploratória dos Dados}

Os resultados obtidos para o teste $F_{\text {max }}$ encontram-se na Tabela 4 , onde verifica-se que foi detectada heterogeneidade (heterocedasticidade) de variâncias entre os tratamentos, para as variáveis diâmetro na região do colo e comprimento de ráquis, cuja razão entre a maior e menor variância era superior a 24. As variáveis altura, número de perfilhos, número de folhas e folhas novas emitidas apresentam homogeneidade de variâncias.

A literatura (Hoaglin et al., 1991 e Alves et al., 1993) sugere, através de técnica de regressão entre o log da média versus log da variância, que o tipo de transformação adequada para estabilizar a variàncias dos tratamentos para diâmetro do colo e para comprimento de ráquis, são respectivamente $\sqrt{x}$ e $1 / \sqrt{x}$.

Tabela 4 - Teste $F_{\text {maximo }}$ para todas as variáveis.

\begin{tabular}{cccccc}
$\begin{array}{c}\text { Diâmetro } \\
\text { do colo }\end{array}$ & $\begin{array}{c}\text { Comprimento } \\
\text { da ráquis }\end{array}$ & Altura & $N{ }^{\circ}$ Perf. & $N{ }^{\circ}$ Folhas & Folhas novas \\
$29,28^{* *}$ & $47,35^{* *}$ & $21,82^{\mathrm{ns}}$ & 17,44 & $4,44^{\mathrm{ns}}$ & $8,00^{\mathrm{ns}}$ \\
\hline
\end{tabular}

ns = não significativo pelo teste de Hartlẹ (Pearson \& Hartley, 1956).

Os histogramas de distribuição de freqüência e box-plot estão representados nas Figuras 1, 2, 3, 4, 5, 6, 7 e 8 (Anexo).

As Figuras 9 e 10 (Anexo) mostram o diagrama de dispersão do log da média versus log da variância sem transformação e após a transformação para as variáveis diâmetro na região do colo e comprimento de ráquis, onde foram detectadas heterogeneidade de variâncias. Na Figura 11 (Anexo) estão os diagramas de dispersão para as variáveis altura, número de perfilhos, número de folhas e folhas novas emitidas, que não necessitam de transformação dos dados. 


\subsection{Análise de Variância e de Regressão}

\subsubsection{Variáveis Analisadas}

Nas Tabelas 5 e 6 são apresentadas as análises da variância das variáveis para as quais foram necessárias transformações de dados, para restabelecer a homogeneidade de variância e das variáveis que não necessitaram de transformação. Por estas tabelas observa-se que houve diferença significativa entre tratamentos para as variáveis diâmetro no colo, altura e emissão de folhas novas, entre tempo para todas as variáveis. Verifica-se também, que houve interação tempo x tratamento, apenas para a variável folhas novas emitidas.

Tabela 5 - Análise de variância e teste $\mathrm{F}$ para as variáveis diâmetro na região do colo, comprimento de ráquis e altura.

\begin{tabular}{|c|c|c|c|c|}
\hline \multirow{2}{*}{ C.V. } & \multirow[b]{2}{*}{ GL } & \multicolumn{3}{|c|}{$\mathbf{Q M}$} \\
\hline & & Diâmetro Colo $^{\mathrm{T}}$ & Comp. Ráquis $^{\mathrm{T}}$ & Altura \\
\hline Blocos & 7 & 0,0029 & 0,0089 & 0,0184 \\
\hline Tratamentos & 3 & $0,0167^{*}$ & $0,025^{\text {ns }}$ & $0,1410 *$ \\
\hline Resíduo (A) & 21 & 0,0024 & 0,0040 & 0,0379 \\
\hline Parcelas & 31 & & & \\
\hline Tempo & 3 & $0,1467 * *$ & $0,0507^{*}$ & $1,9615^{*}$ \\
\hline Temp x Trat & 9 & $0,0024^{\mathrm{ns}}$ & $0,0069^{\mathrm{ns}}$ & $0,0869^{\text {ns }}$ \\
\hline Resíduo (B) & 84 & 0,0015 & 0,0055 & 0,0867 \\
\hline Total & 127 & & & \\
\hline Coef. var. (A) & & $16,42 \%$ & $16,52 \%$ & $22,51 \%$ \\
\hline \multicolumn{5}{|c|}{$\begin{array}{l}* \text { = significativo pelo teste } \mathrm{F} \text { ao nivel de } 1 \% \text { de probabilidade } \\
*=\text { significativo pelo teste } \mathrm{F} \text { ao nivel de } 5 \% \text { de probabilidade } \\
\text { ns = não significativo pelo teste } \mathrm{F}\end{array}$} \\
\hline \multicolumn{5}{|c|}{$\mathrm{T}=$ transformações utilizadas: diâmetro na região do colo: $y=\sqrt{x}$} \\
\hline
\end{tabular}


Tabla 6 - Análise de variância e teste $\mathrm{F}$ para as variáveis número de perfilhos, número de folhas e folhas novas emitidas.

\begin{tabular}{|c|c|c|c|c|}
\hline \multirow[b]{2}{*}{ C.V. } & \multirow[b]{2}{*}{ GL } & \multicolumn{3}{|c|}{ QMI } \\
\hline & & N. ${ }^{\circ}$ Perfilhos & N. ${ }^{\circ}$ Folhas & Folhas Novas \\
\hline Blocos & 7 & 0,0007 & 0,0004 & 0,0001 \\
\hline Tratamentos & 3 & $0,0003^{\mathrm{ns}}$ & $0,0004^{\mathrm{ns}}$ & $0,0011 * *$ \\
\hline Resíduo (A) & 21 & 0,0003 & 0,0003 & 0,0001 \\
\hline Parcelas & 31 & & & \\
\hline Tempo & 3 & $0,0051 * *$ & $0,0011^{*}$ & $0,0103 * *$ \\
\hline Temp x Trat & 9 & $0,0004^{\mathrm{ns}}$ & $0,0003^{\mathrm{ns}}$ & $0,0002 * *$ \\
\hline Resíduo (B) & 84 & 0,0003 & 0,0004 & 0,0001 \\
\hline Total & 127 & & & \\
\hline Coef. var.(A) & & $22,33 \%$ & $10,61 \%$ & $15,86 \%$ \\
\hline
\end{tabular}

Como para quase todas as variáveis analisadas, com exceção da variável folhas novas emitidas, a interação tempo $\mathrm{x}$ tratamento não foi significativa, foi feita análise de regressão somente para o fator tempo.

\subsubsection{Diâmetro no Colo}

Na Tabela 5 observa-se que para a variável diâmetro na região do colo houve diferença significativa entre os tratamentos e entre os tempos, ou seja, os diferentes tratamentos, representados pelos níveis de depleção de água no solo, provocaram diferentes resultados quanto a taxa de acréscimo em diâmetro na região do colo. As médias obtidas para esta variável encontram-se na Tabela 7.

Observa-se na Tabela 7 que o tratamento 1 (25\% $\mathrm{AD})$, não diferiu estatisticamente do tratamento $2(50 \% \mathrm{AD})$, ou seja, as plantas do tratamento 1 que receberam lâminas com maior freqüência (menor turno de rega), apresentaram médias de crescimento em diâmetro no colo semelhantes àquelas do tratamento 2 e superior apenas aos tratamentos 3 e 4 . 
Na Figura 5, que representa a taxa de crescimento diária, em diâmetro no colo, para cada período e para o período total (de 0 aos 168 dias) de avaliação, verifica-se queas maiores taxas médias de crescimento foram obtidas nos tempos 3 e 4 , sendo superiores àquelas obtidas durante o período total de avaliação. Vizquez (1981), em estudo sobre os aspectos fenológiocos da cultura, afirma que os períodos de maior precipitação pluviométrica, corresponderam aos de maior engrossamento do estipe.

Tabela 7 - Médias originais de taxa de crescimento $(\mathrm{cm} / \mathrm{dia})$, da a variável em diâmetro no colo, para o fator tratamento dentro do fator tempo.

\begin{tabular}{|c|c|c|c|c|c|}
\hline & \multicolumn{4}{|c|}{ Médias de Tempo } & \\
\hline Tratamentos & $\begin{array}{l}\text { Tempo } 1 \\
\text { (34 dias) }\end{array}$ & $\begin{array}{l}\text { Tempo } 2 \\
\text { (68 dias) }\end{array}$ & $\begin{array}{l}\text { Tempo } 3 \\
\text { (83 dias) }\end{array}$ & $\begin{array}{l}\text { Tempo } 4 \\
\text { (98 dias) }\end{array}$ & $\begin{array}{c}\text { Médias de } \\
\text { Tratamentos }\end{array}$ \\
\hline $\mathrm{T} 1$ & $0,0177 \mathrm{a}$ & $0,0096 \mathrm{a}$ & $0,0610 \mathrm{a}$ & $0,0587 \mathrm{a}$ & $0,0367 \mathrm{a}$ \\
\hline $\mathrm{T} 2$ & $0,0078 \mathrm{a}$ & $0,0079 \mathrm{a}$ & $0,0426 \mathrm{a}$ & $0,0544 \mathrm{a}$ & $0,0289 \mathrm{ab}$ \\
\hline T3 & $0,0052 \mathrm{a}$ & $0,0058 \mathrm{a}$ & $0,0312 \mathrm{a}$ & $0,0545 \mathrm{a}$ & $0,0242 \quad b$ \\
\hline $\mathrm{T} 4$ & $0,0093 \mathrm{a}$ & $0,0063 \mathrm{a}$ & $0,0275 \mathrm{a}$ & $0,0372 \mathrm{a}$ & $0,0268 \quad b$ \\
\hline Médias & 0,0101 & 0,0074 & 0,0405 & 0,0512 & 0,0291 \\
\hline
\end{tabular}

Médias seguidas de letras iguais na vertical não diferem entre si pelo teste de Tukey ao nível de $5 \%$ de probabilidade.

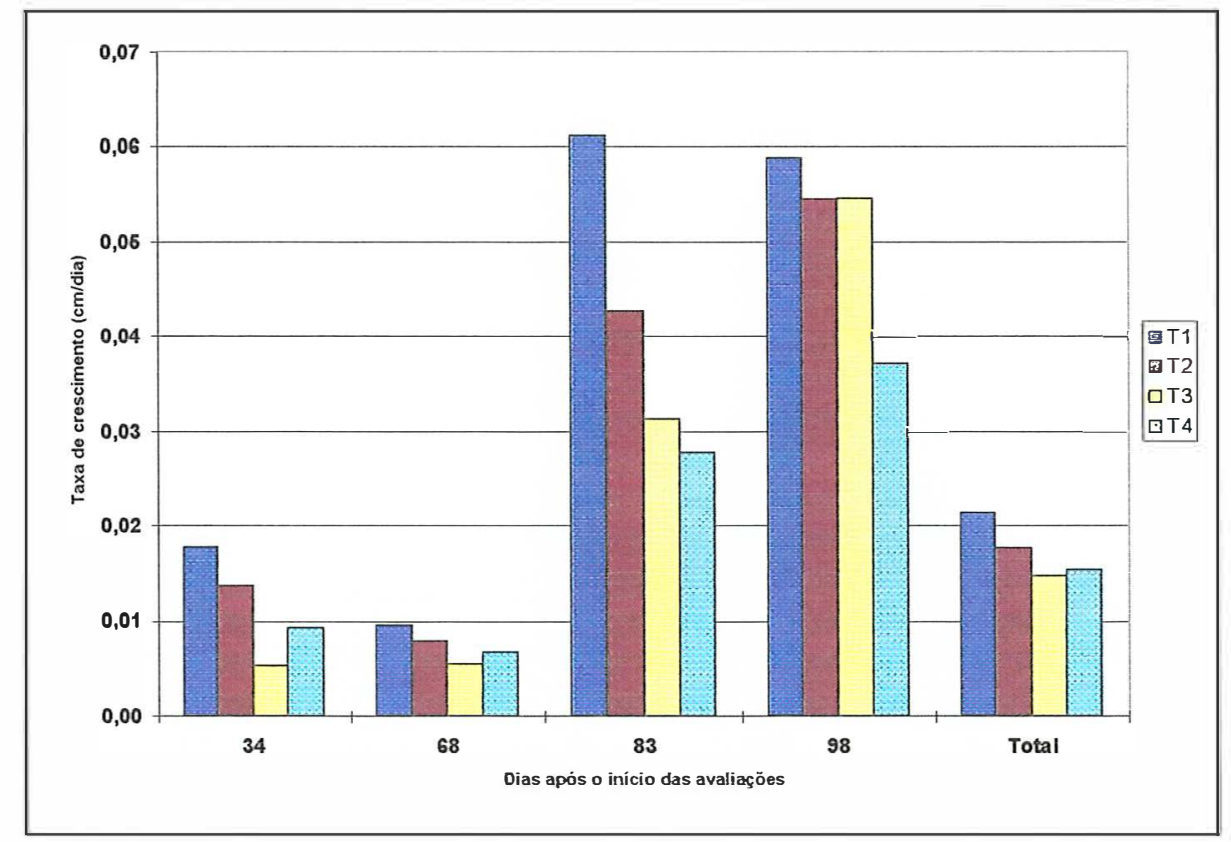

Figura 5 - Taxa de crescimento médio da variável diâmetro no colo $(\mathrm{cm} / \mathrm{dia})$, para os diferentes tratamentos, para cada período e período total de avaliação. 
As Figuras abaixo mostram o comportamento desta variável (curva de crescimento), para o qual obteve-se ajuste para a regressão, significativo pelo Teste $\mathrm{F}$.

As Figuras 6 e 7 representam o crescimento das variáveis em função dos tratamentos impostos, para cada periodo de avaliação (aos 0, 34, 68, 83 e 98 dias) e as equações e curvas de regressões obtidas. Utilizou-se as equações de regressão para corrigir as oscilações normais, permitindo assim, avaliar a tendència do crescimento em função da idade da planta (do periodo de avaliação). A utilização de equações de regressão para representar a progressão do crescimento ao longo do ciclo permite avaliar de forma mais precisa, variações no padrão de crescimento de plantas em relação a um atributo (como altura, entre outros) em função dos tratamentos impostos ou de variabilidade genética (Benincasa, 1986).

As Figuras 8 e 9 representam o crescimento durante todo periodo irrigado e mais duas avaliações realizadas após o término dos tratamentos (aos 133 e 168) e suas regressões, para a variável diâmetro no colo. Essas figuras foram feitas com o objetivo de se ter uma visualização do comportamento da curva de crescimento desta variável por um maior período.

Na Figura 6 observa-se que durante as irrigações $(34,68,83$ e 98 dias) o crescimento das plantas foi mais acentuado, para todos os tratamentos, a partir dos 68 dias (08/10), principalmente aos 83 (23/10) e 98 (7/11) dias, à medida em que os períodos de avaliação diminuíram de 34 para 15 dias, sendo que nesses tempo ocorreram as maiores taxas de crescimento, como pode ser observado na Figura 5. Isso deve ter ocorrido devido ao manejo da irrigação, e está de acordo com os resultados obtidos pelo balanço hídrico, onde também a partir desses período, ocorreram os maiores valores de evapotranspiração da cultura (Tabela 4).

Na Figura 7 apresentam-se os ajustes da regressão para as curvas referentes aos tratamentos. Não optou-se pelo ajuste quadrático pois este apontava os primeiros dias de avaliação como o ponto mínimo, uma vez que a partir da primeira avaliação, a cultura apresentou crescimento em função do tempo e tratamentos impostos, para cada período 
avaliado. Sendo assim, optou-se pelo ajuste exponencial já que os desvios da regressão foram significativos.

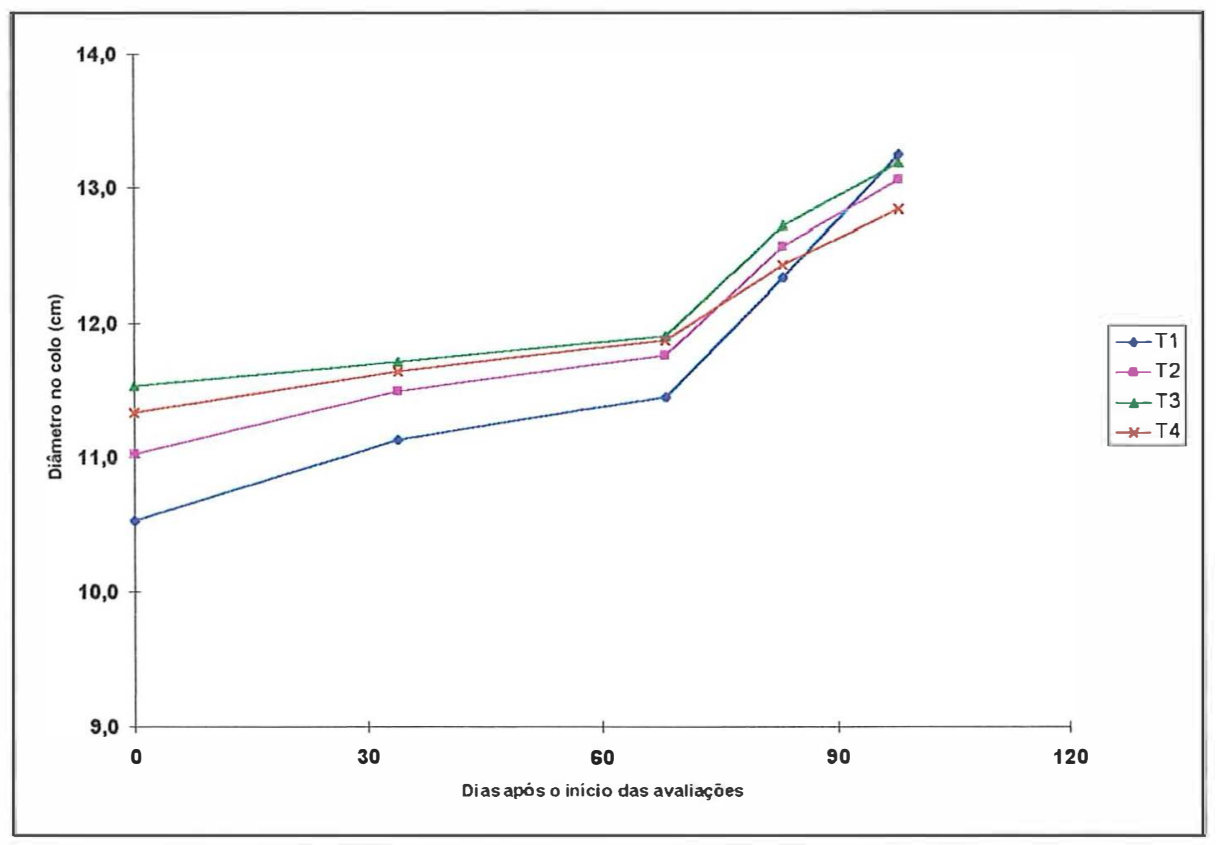

Figura 6 - Crescimento médio em diâmetro na região do colo em função dos períodos de avaliação e dos tratamentos impostos, para os períodos irrigados.

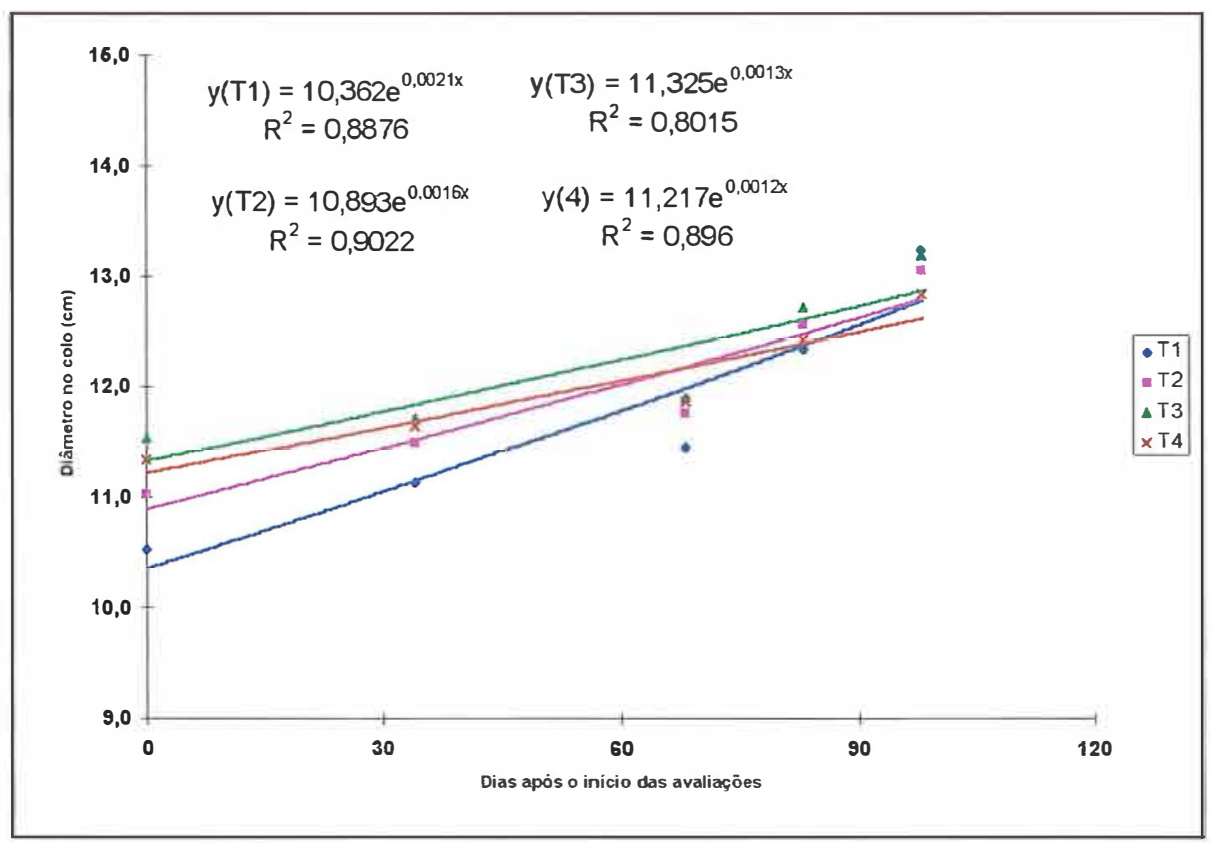

Figura 7 - Curvas e equações de regressão entre o diâmetro do colo e os períodos de avaliação, para os períodos irrigados. 
A inclusão desses dois últimos períodos de análise (aos 133 e 168 dias) possibilitam um melhor ajuste da equação de regressão, o que pode ser verificado pelos coeficientes de determinação (Figura 9). Verifica-se também, uma tendência de estabilização do crescimento do diâmetro no colo para todos os tratamentos (Figura 8), e isto pode ter ocorrido devido ao elevado índice de precipitação e ao aumento da temperatura e umidade relativa (Figura 4) nos meses de novembro e dezembro.

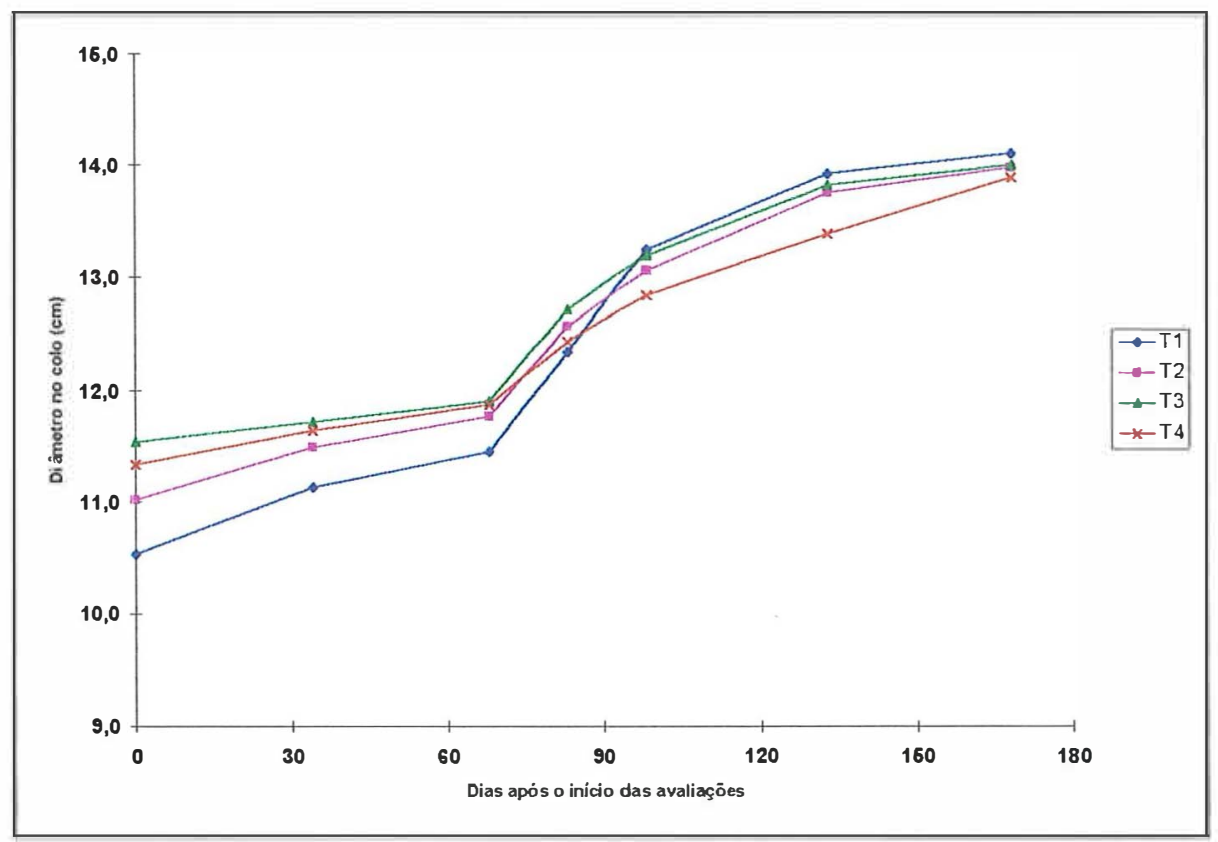

Figura 8 - Crescimento médio em diâmetro na região do colo em função do período de avaliação para todo período avaliado. 


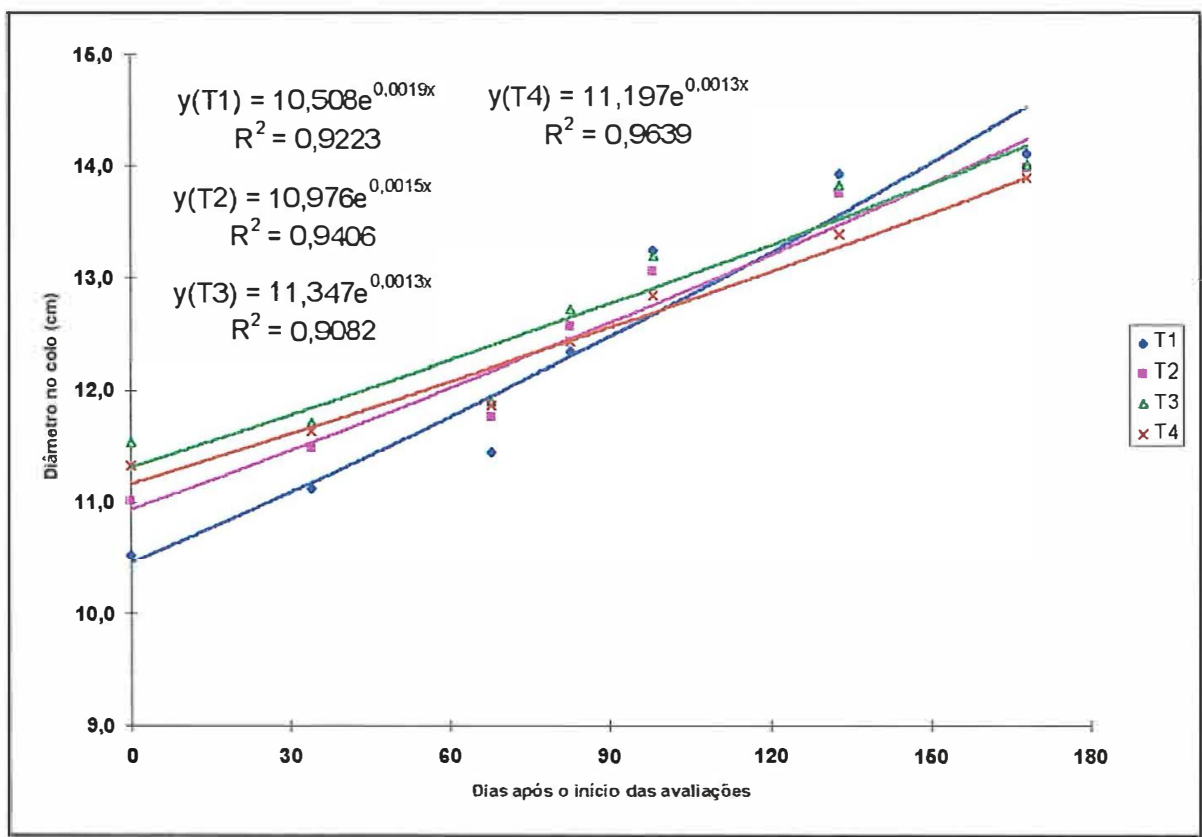

Figura 9 - Curvas e equações de regressão entre o diâmetro do colo e o período de avaliação, para todo período avaliado.

\subsubsection{Comprimento da Ráquis}

Verifica-se pela Tabela 8 que não houve diferença significativa entre tratamentos e nem entre os tratamentos dentro dos tempos para a variável comprimento da ráquis.

Tabela 8 - Médias originais de taxa de crescimento $(\mathrm{cm} / \mathrm{dia})$, da variável comprimento de ráquis, para o fator tratamento dentro do fator tempo.

\begin{tabular}{c|c|c|c|c|c}
\hline & \multicolumn{4}{|c|}{ Médias de Tempo } & \\
\hline Tratamentos & $\begin{array}{c}\text { Tempo 1 } \\
\text { (34 dias) }\end{array}$ & $\begin{array}{c}\text { Tempo 2 } \\
\text { (68 dias) }\end{array}$ & $\begin{array}{c}\text { Tempo 3 } \\
\text { (83 dias) }\end{array}$ & $\begin{array}{c}\text { Tempo 4 } \\
\text { (98 dias) }\end{array}$ & $\begin{array}{c}\text { Médias de } \\
\text { Tratamentos }\end{array}$ \\
\hline $\mathrm{T} 1$ & $0,0060 \mathrm{a}$ & $0,1116 \mathrm{a}$ & $0,3670 \mathrm{a}$ & $0,1762 \mathrm{a}$ & 0,1787 \\
\hline $\mathrm{T} 2$ & $0,1370 \mathrm{a}$ & $0,0301 \mathrm{a}$ & $0,3415 \mathrm{a}$ & $0,1418 \mathrm{a}$ & 0,1627 \\
\hline $\mathrm{T} 3$ & $0,1131 \mathrm{a}$ & $0,0406 \mathrm{a}$ & $0,1501 \mathrm{a}$ & $0,2863 \mathrm{a}$ & 0,1475 \\
\hline $\mathrm{T} 4$ & $0,1111 \mathrm{a}$ & $0,0428 \mathrm{a}$ & $0,2184 \mathrm{a}$ & $0,2025 \mathrm{a}$ & 0,436 \\
\hline Médias & $\mathbf{0 , 1 0 5 3}$ & $\mathbf{0 , 0 5 6 2}$ & $\mathbf{0 , 2 6 9 3}$ & $\mathbf{0 , 2 0 1 7}$ & $\mathbf{0 , 1 5 8 1}$ \\
\hline
\end{tabular}

Médias seguidas de letras iguais na vertical não diferem entre si pelo teste de Tukey ao nível de $5 \%$ de probabilidade.

A figura abaixo (Figura 10) representa a curva de crescimento para comprimento da ráquis, obtida pela média dos quatro tratamentos, em função dos períodos de 
avaliação, incluindo os períodos irrigados e sem irrigação. Apresenta-se a curva média considerando-se o fato de que não houve diferença significativa entre os tratamentos.

Esta variável apresentou um crescimento mais acentuado a partir dos 68 dias $(08 / 10)$ do início das avaliações, isto deve ter ocorrido como resposta às lâminas de irrigação recebidas mais precipitações e aos aumentos da temperatura e umidade relativa que ocorreram a partir do mês de setembro (Figura 4)

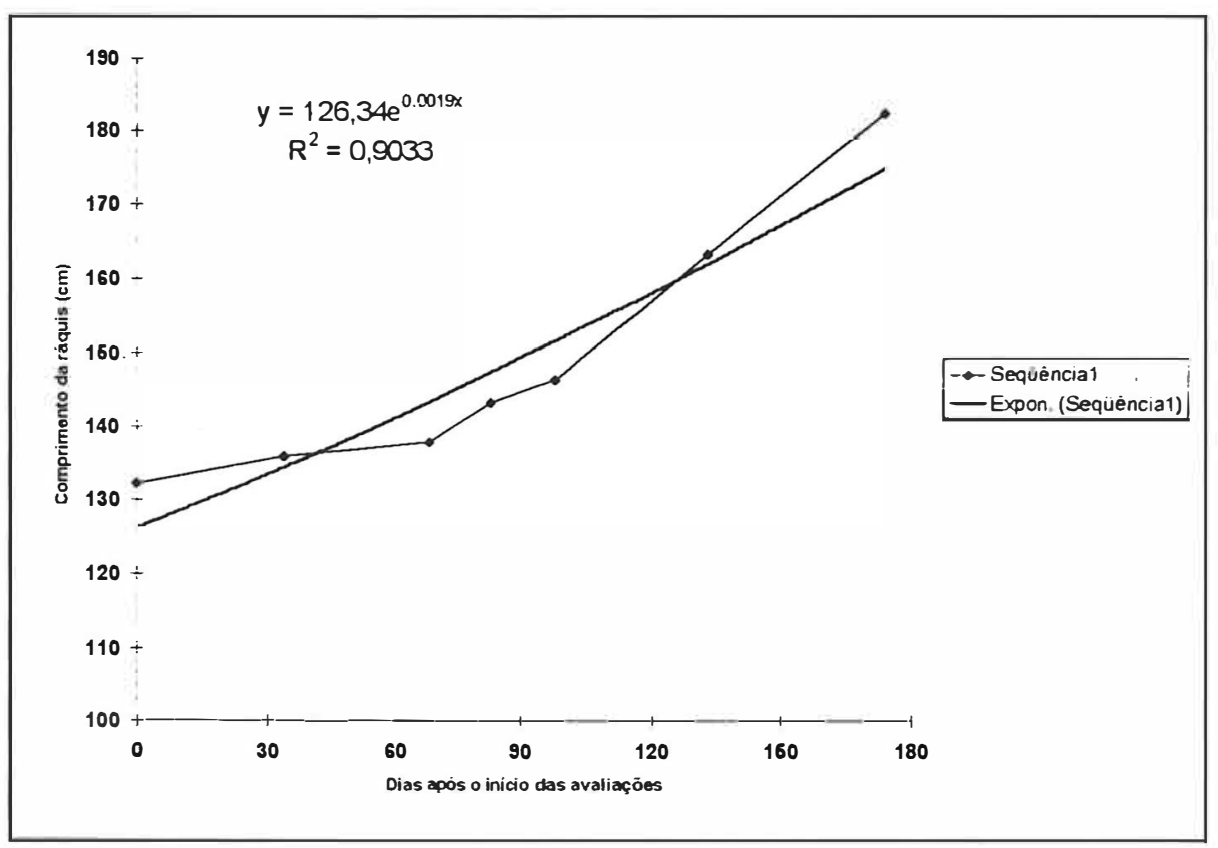

Figura 10 - Crescimento médio da variável comprimento da ráquis em função do periodo de avaliação, para todo período avaliado e equação de regressão.

\subsubsection{Altura}

A Tabela 9 mostra que houve diferença significativa entre tempo e tratamento, e sem interação entre os tratamentos dentro dos tempos, para essa variável. O tratameno $1(25 \%$ AD) diferiu estatísticamente apenas do tratamento 4 (testemunha). Esta diferença entre os tratamentos 1 e 4, ocorreu no tempo 2, aos 68 dias, como verifica-se na Figura 11. Observa-se também, que as maiores taxas de crescimento, para todos os tratamentos, foram obtidas nos tempos 3 (aos 83 dias)e 4 (aos 98 dias). 
Tabela 10 - Médias originais de taxa de crescimento $(\mathrm{cm} /$ dia $)$, da variável altura, para o fator tratamento dentro do fator tempo.

\begin{tabular}{c|c|c|c|c|c}
\hline & \multicolumn{4}{|c|}{ Médias de Tempo } & \\
\hline Tratamentos & $\begin{array}{c}\text { Tempo 1 } \\
\text { (34 dias) }\end{array}$ & $\begin{array}{c}\text { Tempo 2 } \\
\text { (68 dias) }\end{array}$ & $\begin{array}{c}\text { Tempo 3 } \\
\text { (83 dias) }\end{array}$ & $\begin{array}{c}\text { Tempo 4 } \\
\text { (98 dias) }\end{array}$ & $\begin{array}{c}\text { Médias de } \\
\text { Tratamentos }\end{array}$ \\
\hline $\mathrm{T} 1$ & 0,1757 & 0,3390 & 0,7092 & 0,7932 & $0,5042 \mathrm{a}$ \\
\hline $\mathrm{T} 2$ & 0,2286 & 0,2366 & 0,6852 & 0,5190 & $0,4173 \mathrm{ab}$ \\
\hline $\mathrm{T} 3$ & 0,2336 & 0,1646 & 0,5895 & 0,8666 & $0,4635 \mathrm{ab}$ \\
\hline $\mathrm{T} 4$ & 0,2222 & 0,1601 & 0,4551 & 0,5552 & $0,3485 \quad \mathrm{~b}$ \\
\hline Médias & $\mathbf{0 , 2 1 4 8}$ & $\mathbf{0 , 9 0 1 8}$ & $\mathbf{0 , 6 0 9 8}$ & $\mathbf{0 , 6 8 3 5}$ & $\mathbf{0 , 4 3 3 4}$ \\
\hline
\end{tabular}

Médias seguidas de letras iguais na vertical não diferem entre si pelo teste de Tukey ao nível de $5 \%$ de probabilidade.

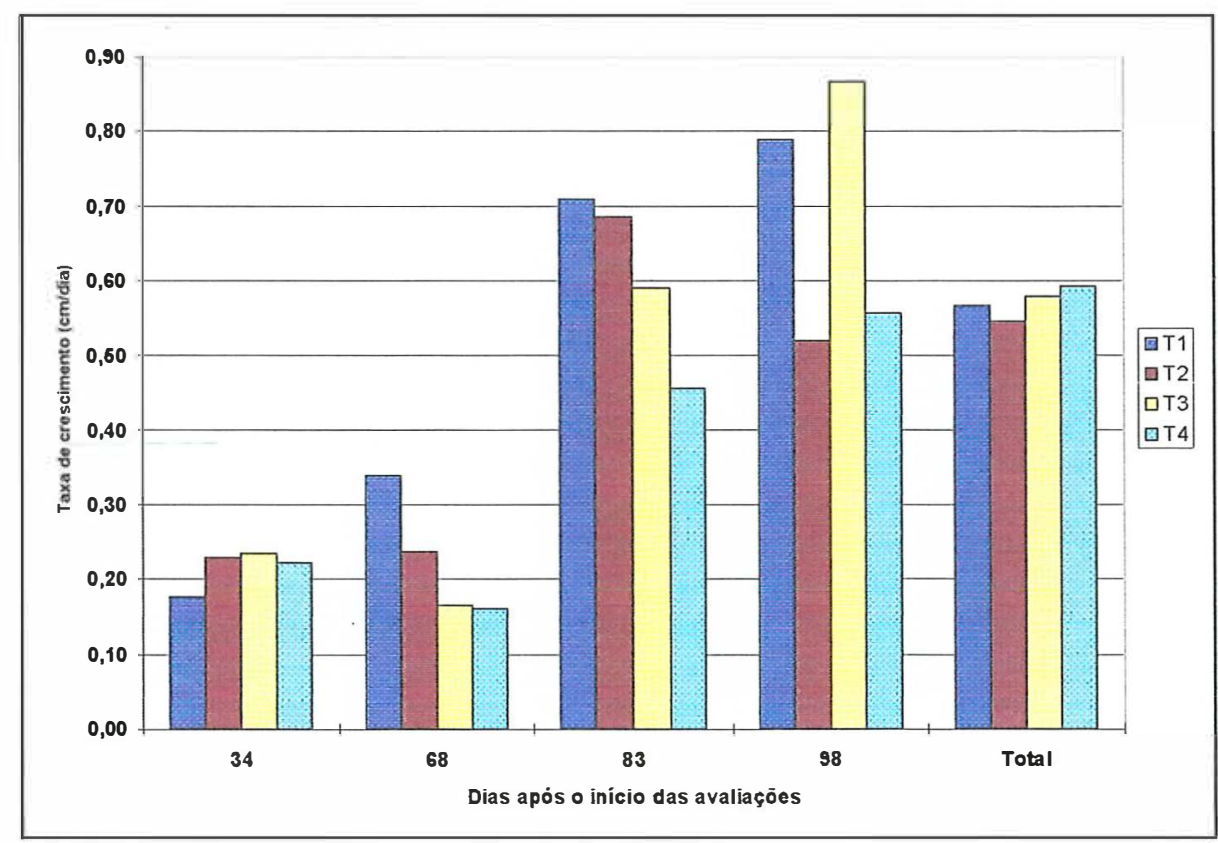

Figura 11 - Taxa de crescimento médio da variável altura $(\mathrm{cm} /$ dia $)$ para os diferentes tratamentos, para cada período e período total de avaliação.

A Figura 12 representa a curva de crescimento em altura obtida pelos diferentes tratamentos em função de todos os períodos de avaliação, onde observa-se um maior crescimento em altura nas avaliações realizadas aos 68 (08/10), $83(23 / 10)$ e 98 (07/11) dias. Mesmo para as avaliações realizadas após o término das irrigações aos 133 (12/12/97) e 168 (16/01/98) (Figura 14) a cultura continuou apresentando o mesmo padrão de crescimento em relação aos períodos irrigados, isto é, com crescimento 
acentuado. Vizquez (1981), encontrou uma relação positiva entre precipitação e crescimento em altura do estipe, ainda que este crescimento não foi proporcional aos meses de maior precipitação.

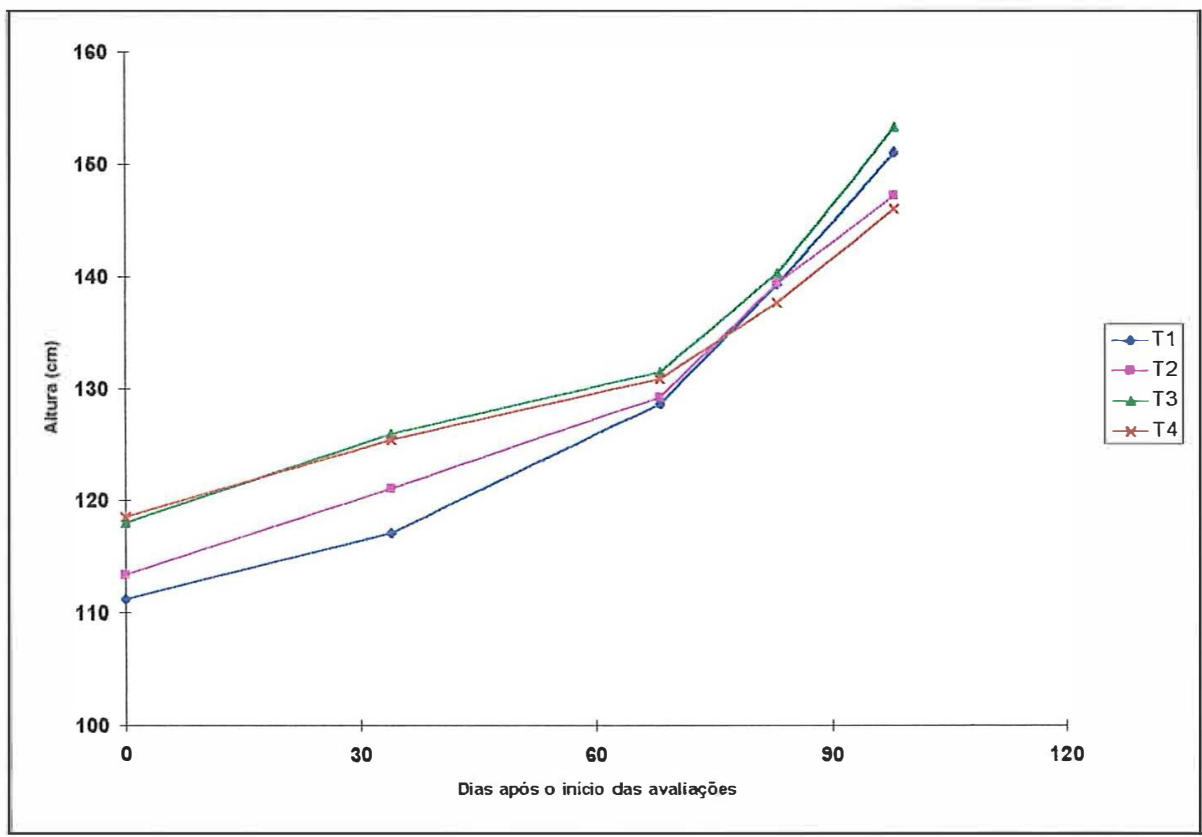

Figura 12 - Crescimento médio em altura em função da idade dacultura após o início das avaliações, para os períodos irrigados.

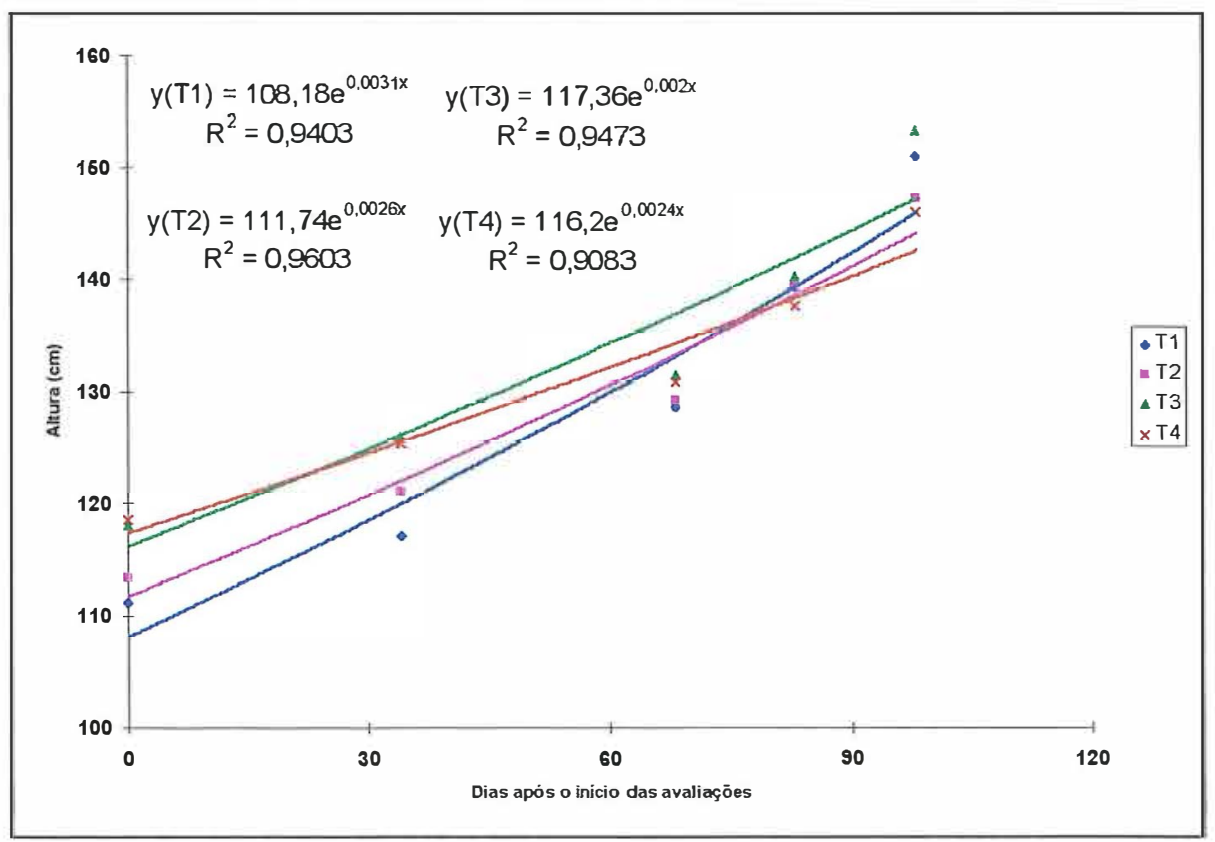

Figura 13 - Curvas e equações de regressão entre a altura e o período de avaliação, para os períodos irrigados. 


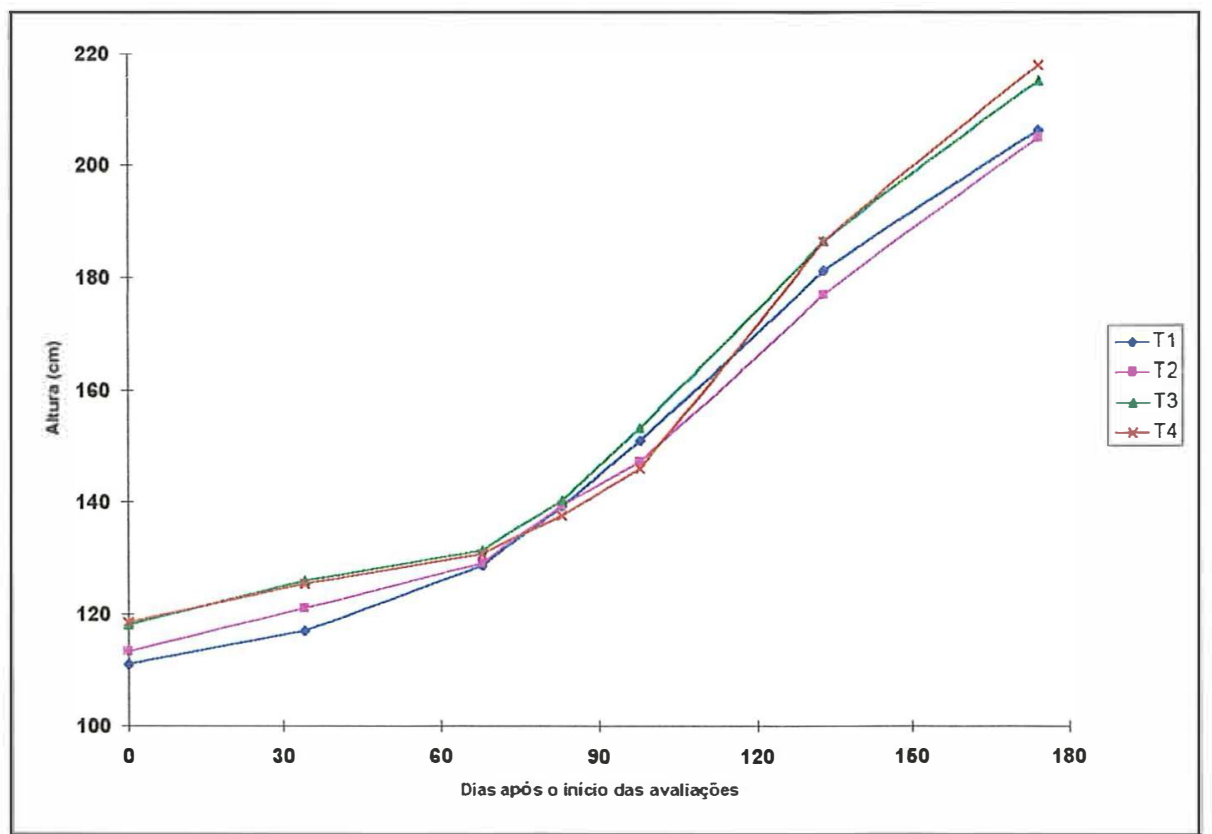

Figura 14 - Crescimento médio em altura em função do período de avaliação para todo período avaliado.

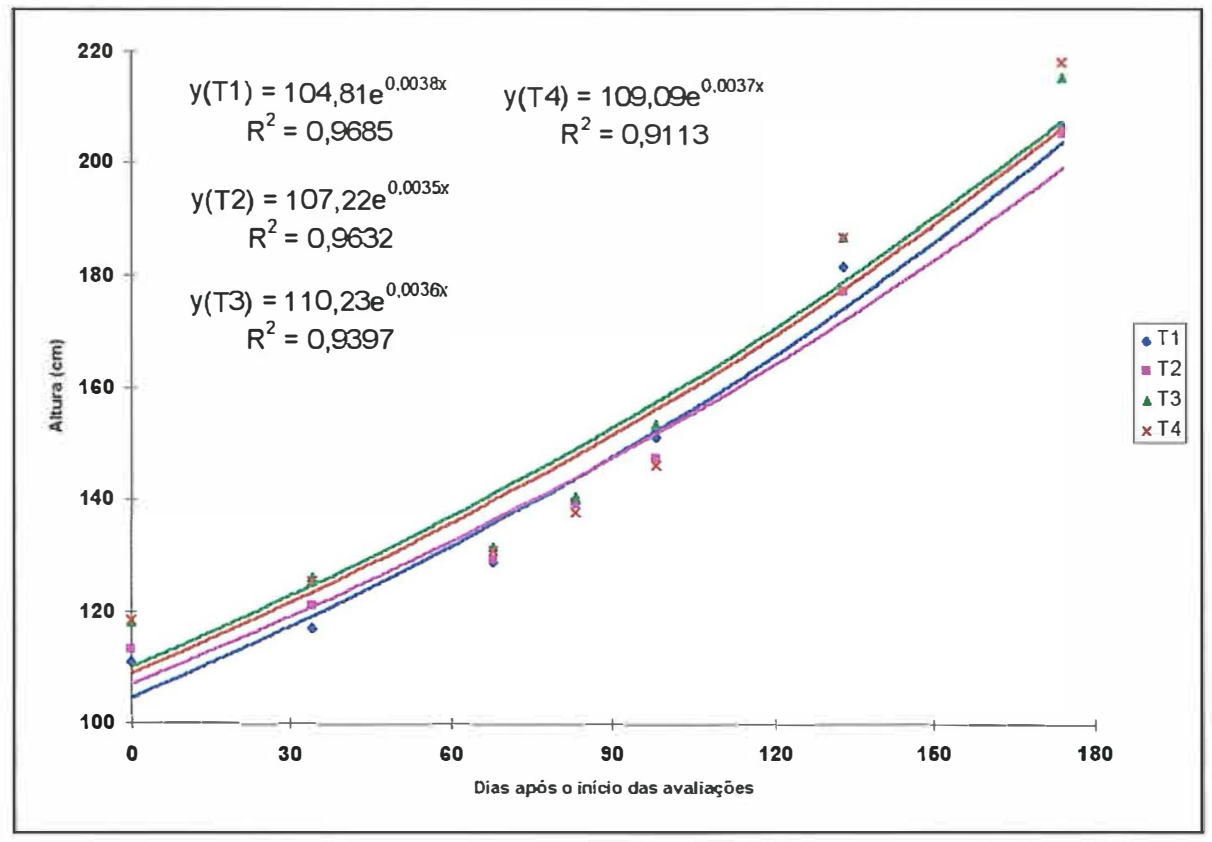

Figura 15 - Curvas e equações de regressão entre a altura e o periodo de avaliação, para todo período avaliado. 


\subsubsection{Número de Perfilhos}

As médias de taxa de crescimento da variável número de perfilhos obtidas para cada tratamento, não diferiram estatisticamente entre si, ou seja, os diferentes tratamentos não resultaram em distintos valores de acréscimo (Tabela 10).

Tabela 10 - Médias originais de taxa de crescimento $(\mathrm{cm} / \mathrm{dia})$, da variável número de perfilhos, para o fator tratamento dentro do fator tempo.

\begin{tabular}{|c|c|c|c|c|c|}
\hline & \multicolumn{4}{|c|}{ Médias de Tempo } & \\
\hline Tratamentos & $\begin{array}{l}\text { Tempo } 1 \\
\text { (34 dias) }\end{array}$ & $\begin{array}{l}\text { Tempo } 2 \\
\text { (68 dias) }\end{array}$ & $\begin{array}{l}\text { Tempo } 3 \\
(83 \text { dias })\end{array}$ & $\begin{array}{l}\text { Tempo } 4 \\
\text { (98 dias) }\end{array}$ & $\begin{array}{c}\text { Médias de } \\
\text { Tratamentos }\end{array}$ \\
\hline $\mathrm{T} 1$ & $0,0118 \mathrm{a}$ & $0,0008 \mathrm{a}$ & $0,0062 \mathrm{a}$ & $0,0376 \mathrm{a}$ & $0,0142 \mathrm{a}$ \\
\hline $\mathrm{T} 2$ & $0,0128 \mathrm{a}$ & $0,0017 \mathrm{a}$ & $0,0000 \mathrm{a}$ & $0,0166 \mathrm{a}$ & $0,0078 \mathrm{a}$ \\
\hline T3 & $0,0065 \mathrm{a}$ & $0,0018 \mathrm{a}$ & $0,0000 \mathrm{a}$ & $0,0436 \mathrm{a}$ & $0,0130 \mathrm{a}$ \\
\hline T4 & $0,0137 \mathrm{a}$ & $0,0125 \mathrm{a}$ & $0,0041 \mathrm{a}$ & $0,0228 \mathrm{a}$ & $0,0133 \mathrm{a}$ \\
\hline Médias & 0,0112 & 0,0042 & 0,0026 & 0,0193 & 0,0121 \\
\hline
\end{tabular}

Médias seguidas de letras iguais na vertical não diferem entre si pelo teste de Tukey ao nivel de $5 \%$ de probabilidade.

Verifica-se na Tabela 10 que as taxas de crescimento diário foram maiores no tempo 1, diminuiram nos tempos 2 e 3, aumentando novamente no tempo 4; o que indica um período de acréscimo, seguido por um período de estabilização.

Como para esta variável também não houve diferença significativa entre os tratamentos, a Figura 16 representa o número médio de perfilhos obtido média dos quatro tratamentos em função do período de avaliação, para todo período avaliado, incluindo os períodos irrigados e sem irrigação. Na Figura 16 observa-se uma mudança no comportamento da curva de crescimento a partir dos 68 dias (avaliação realizada em 08/10) com crescimento mais acentuado até os 98 dias (avaliação realizada em 07/11), sendo que ao final dos períodos avaliados, aos 168 dias, pode-se observar certa tendência de estabilização do crescimento. 


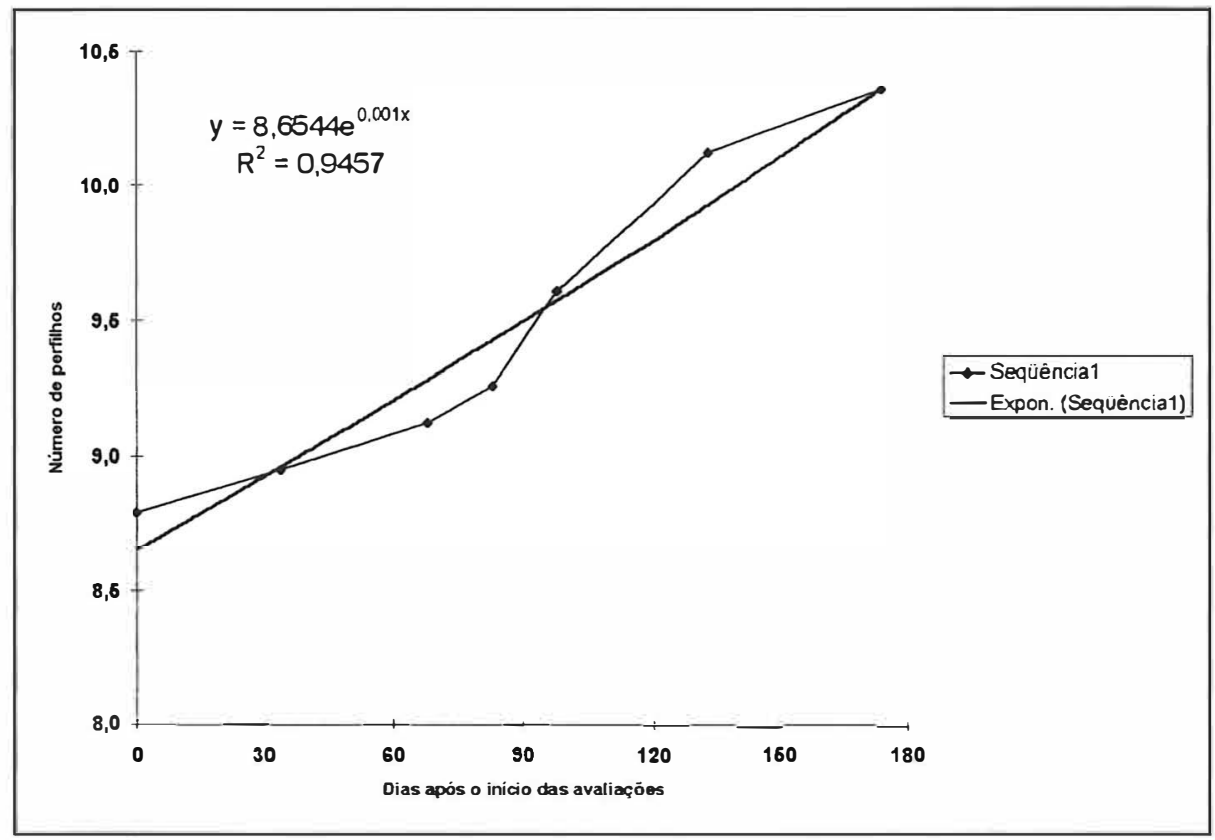

Figura 16 - Número medido perfilhos em função do período de avaliação, para todo período avaliado

\subsubsection{Número de Folhas}

$\mathrm{Na}$ Tabela 11 verifica-se que não houve diferença significativa entre o número médio de folhas obtidos, ou seja, os diferentes níveis de depleção de água no solo não provocaram diferentes resultados em relação ao número de folhas obtidos para os diferentes tratamentos.

Tabela 11 - Médias originais de taxa de crescimento $(\mathrm{cm} / \mathrm{dia})$, da variável número de folhas, para o fator tratamento dentro do fator tempo.

\begin{tabular}{|c|c|c|c|c|c|}
\hline & \multicolumn{4}{|c|}{ Médias de Tempo } & \multirow[b]{2}{*}{$\begin{array}{l}\text { Médias de } \\
\text { Tratamentos }\end{array}$} \\
\hline Tratamentos & $\begin{array}{l}\text { Tempo } 1 \\
\text { (34 dias) }\end{array}$ & $\begin{array}{l}\text { Tempo } 2 \\
(68 \text { dias })\end{array}$ & $\begin{array}{l}\text { Tempo } 3 \\
(83 \text { dias })\end{array}$ & $\begin{array}{l}\text { Tempo } 4 \\
\text { (98 dias) }\end{array}$ & \\
\hline $\mathrm{T} 1$ & 0,0072 & 0,0110 & 0,0021 & 0,0146 & $0,0084 \mathrm{a}$ \\
\hline $\mathrm{T} 2$ & 0,0220 & 0,0091 & 0,0166 & 0,0166 & $0,0161 \mathrm{a}$ \\
\hline T3 & 0,0053 & 0,0128 & 0,0000 & 0,0167 & $0,0087 \mathrm{a}$ \\
\hline $\mathrm{T} 4$ & 0,0065 & 0,0091 & 0,0000 & 0,0271 & $0,0106 \mathrm{a}$ \\
\hline Médias & 0,0102 & 0,0105 & 0,0046 & 0,0187 & 0,0109 \\
\hline
\end{tabular}

Médias seguidas de letras iguais na vertical não diferem entre si pelo teste de Tukey ao nivel de $5 \%$ de probabilidade. 
Para esta variável também foi feito um gráfico de crescimento do número médio de folhas representado pela média dos quatro tratamentos, em função do período de avaliação, uma vez que os tratamentos não diferiram estatisticamente entre si.

A curva de crescimento da variável número de folhas apresentou comportamento de crescimento semelhante ao da variável número de perfilhos, com exceção da avaliação realizada aos 98 dias (07/11), onde o crescimento foi menos acentuado (Figura 17) para esta variável.

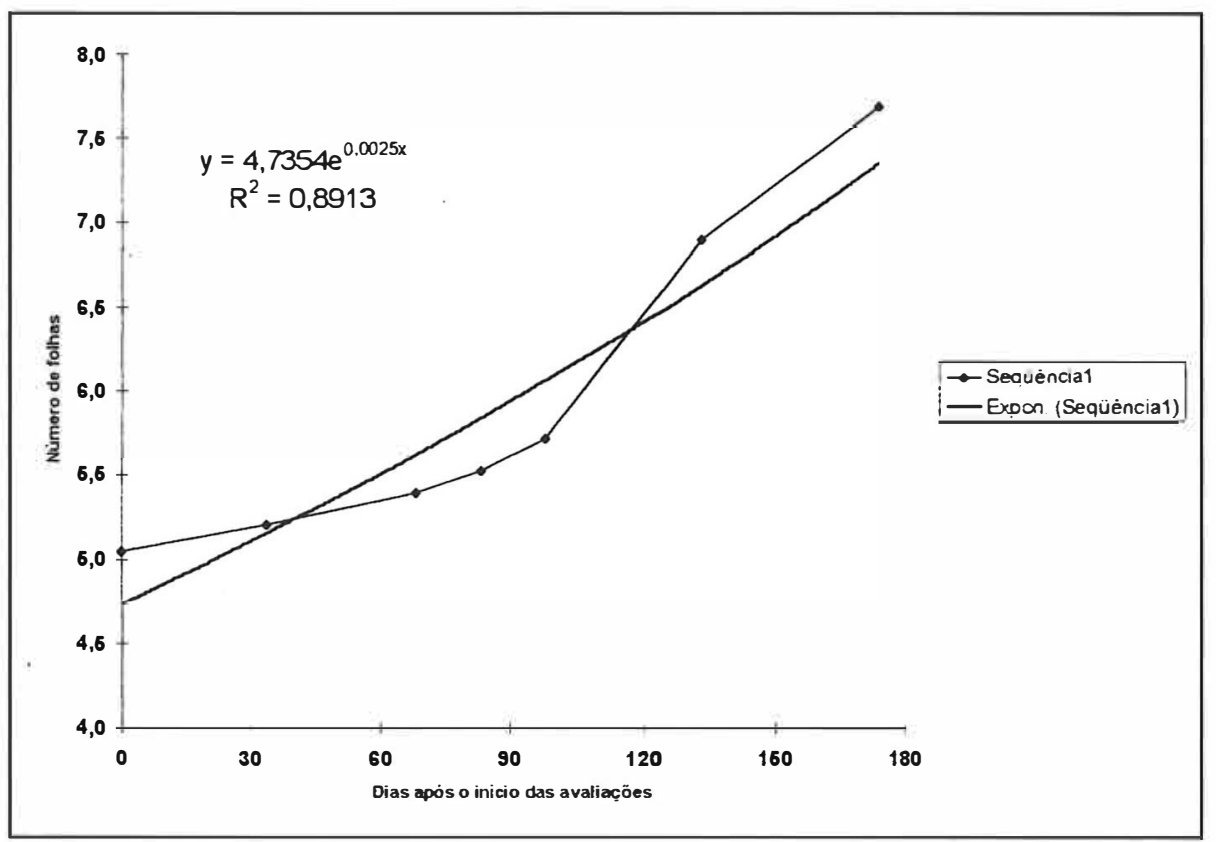

Figura 17 - Número médio de folhas em função do período de avaliação, para todo período avaliado.

\subsubsection{Folhas Novas Emitidas}

Para a variável folhas novas emitidas, verifica-se pela Tabela 12, que houve diferença significativa entre os tratamentos, sendo que o tratamento 1 (25\% $\mathrm{AD})$ foi superior aos demais tratamentos. Verifica-se, também, que a interação tempo $\mathrm{x}$ tratamento foi significativa nos tempos 3 ( 83 dias) e 4 (98 dias), onde as maiores taxas de crescimento foram obtidas para o tratamento 1 ( $25 \%$ AD), em relação aos tratamentos 2 , 3 e 4.Isto pode ser verificado na Figura 18. Sendo assim, foram feitos os gráficos de 
crescimento desta variável, para cada tratamento, em função do período de avaliação e tratamentos impostos, para os períodos irrigados $(0,34,68$ e 98 dias após o início das avaliações) (Figura 19) e gráfico da regressão (Figura 20). Foram feitos também os gráficos para todo período avaliado, incluindo aos períodos irrigados os períodos sem irrigação (avaliações realizadas aos 133 e 168 dias) (Figura 21) e as regressões para o ajuste dessas curvas não foram significativas (Figura 22).

Tabela 13 - Médias originais de taxa de emissão, da variável folhas novas, para o fator tratamento dentro do fator tempo.

\begin{tabular}{c|c|c|c|c|c}
\hline & \multicolumn{4}{|c|}{ Médias de Tempo } & \\
\hline Tratamentos & $\begin{array}{c}\text { Tempo 1 } \\
\text { (34 dias) }\end{array}$ & $\begin{array}{c}\text { Tempo 2 } \\
\text { (68 dias) }\end{array}$ & $\begin{array}{c}\text { Tempo 3 } \\
\text { (83 dias) }\end{array}$ & $\begin{array}{c}\text { Tempo 4 } \\
\text { (98 dias) }\end{array}$ & $\begin{array}{c}\text { Médias de } \\
\text { Tratamentos }\end{array}$ \\
\hline T1 & $0,0111 \mathrm{a}$ & $0,0272 \mathrm{a}$ & $0,0627 \mathrm{a}$ & $0,0585 \mathrm{a}$ & $0,0398 \mathrm{a}$ \\
\hline $\mathrm{T} 2$ & $0,1100 \mathrm{a}$ & $0,0202 \mathrm{a}$ & $0,0458 \mathrm{~b}$ & $0,0394 \mathrm{~b}$ & $0,0291 \mathrm{~b}$ \\
\hline $\mathrm{T} 3$ & $0,0108 \mathrm{a}$ & $0,0201 \mathrm{a}$ & $0,0457 \mathrm{~b}$ & $0,0394 \mathrm{~b}$ & $0,0291 \mathrm{~b}$ \\
\hline T4 & $0,0108 \mathrm{a}$ & $0,0108 \mathrm{a}$ & $0,0437 \mathrm{~b}$ & $0,0334 \mathrm{~b}$ & $0,0268 \mathrm{~b}$ \\
\hline Médias & $\mathbf{0 , 0 3 5 6}$ & $\mathbf{0 , 0 1 9 6}$ & $\mathbf{0 , 0 4 9 5}$ & $\mathbf{0 , 0 4 2 6}$ & $\mathbf{0 , 0 3 1 2}$ \\
\hline
\end{tabular}

Médias seguidas de letras iguais na vertical não diferem entre si pelo teste de Tukey ao nível de $5 \%$ de probabilidade.

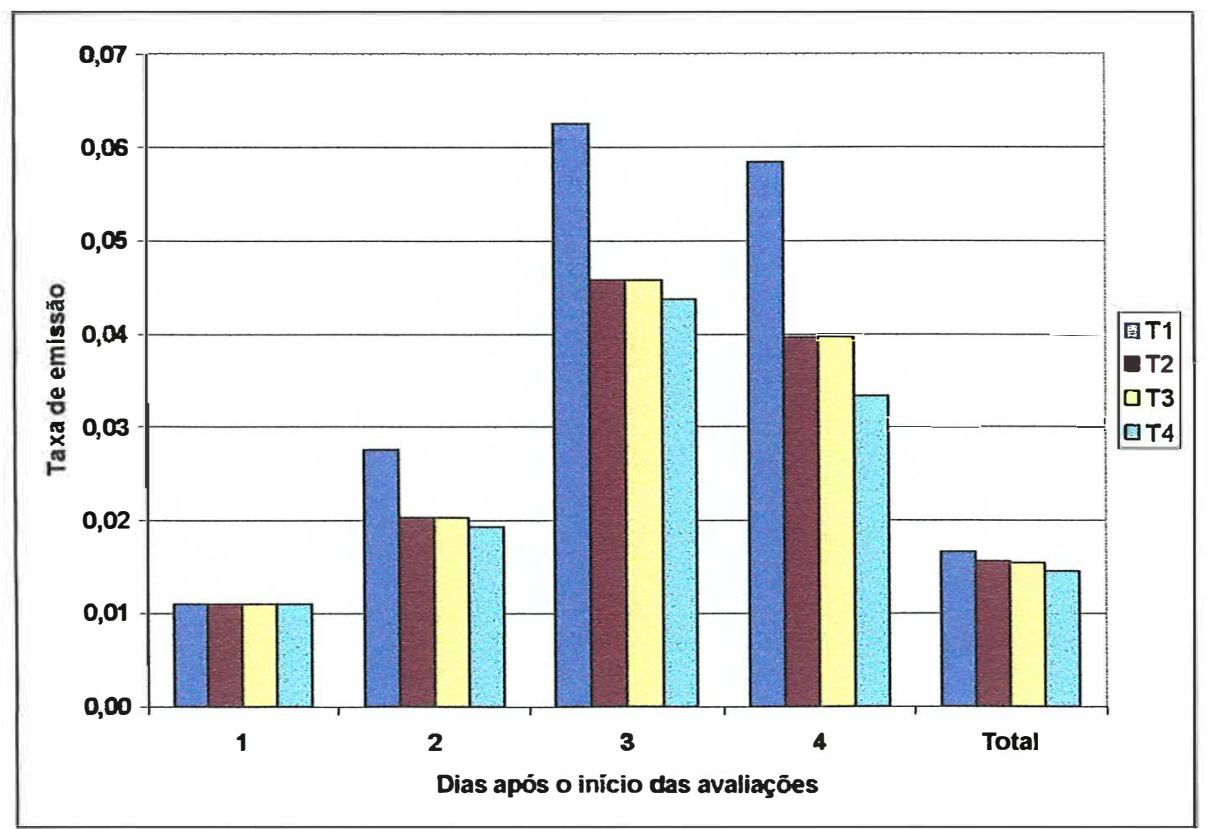

Figura 18 - Taxa de emissão da variável folhas novas emitidas para os diferentes tratamentos, para cada período e período total de avaliação. 
Na Figura 19 observa-se que o tratamento 1(25\% AD) foi durante todo período irrigado superior aos tratamentos 2,3 e 4, ou seja, as plantas do tratamento 1 emitiram um maior número de folhas novas, como resposta às irrigações realizadas a menores turnos de rega quando comparadas às plantas dos demais tratamentos. Observa-se também que as plantas do tratamento 2 tiveram o mesmo comportamento do que àquelas pertencentes aos tratamentos 3 e 4, onde verifica-se pela Figura 20 que a equação de regressão polinomial obtida foi a mesma para estes tratamentos.

Como a planta emitiu um menor número de folhas novas na avaliação realizada aos 34 dias (04/09) quando comparada com a próxima avaliação realizada aos 68 dias (08/10), próximo a este período será o ponto de mínimo, por isto optou-se pelo ajuste quadrático, onde para o tratamento 1 , o ponto de mínimo foi de 33 dias; para o tratamento 2 e 3 foi de 46 dias e 65 dias para o tratamento 4 .

Na Figura 21 observa-se que nas avaliações realizadas aos 133 (12/12/97) e 168 (16/01/07), periodo este sem irrigação, praticamente todos os tratamentos se igualaram, e isto deve ter ocorrido em função do alto índice de precipitação pluviométrica que ocorreram neste período. Aos 133 dias todas as plantas emitiram em média de 2 folhas, já aos 168 dias, ocorreu a emissão de aproximadamente uma folha nova para todas as plantas. Esse maior número de folhas novas emitidas aos 133 dias pode ter ocorrido porque dos meses de avaliação (agosto/97 a janeiro de 98) o mês de novembro foi o que teve a maior temperatura, umidade relativa e precipitação associados (Figura 4). 


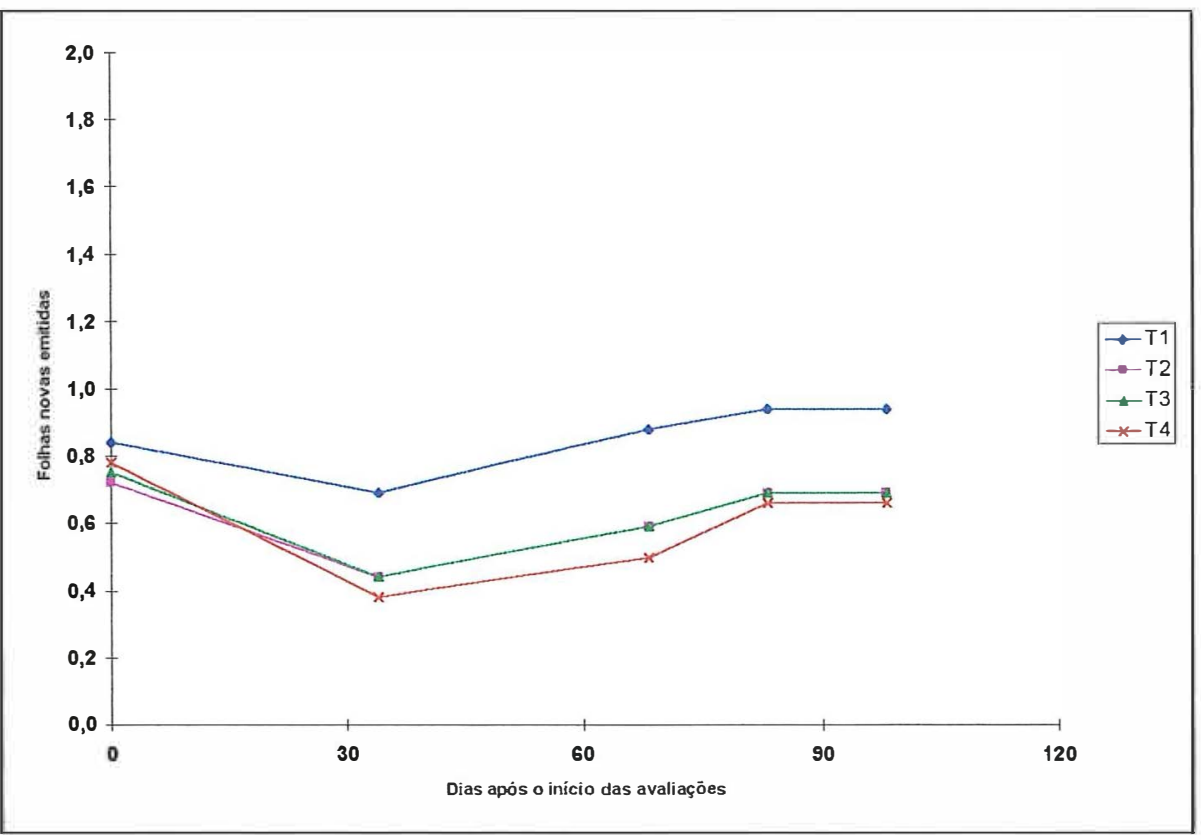

Figura 19 - Média do número de folhas novas emitidas em função de período de avaliações, para o períodos irrigado.

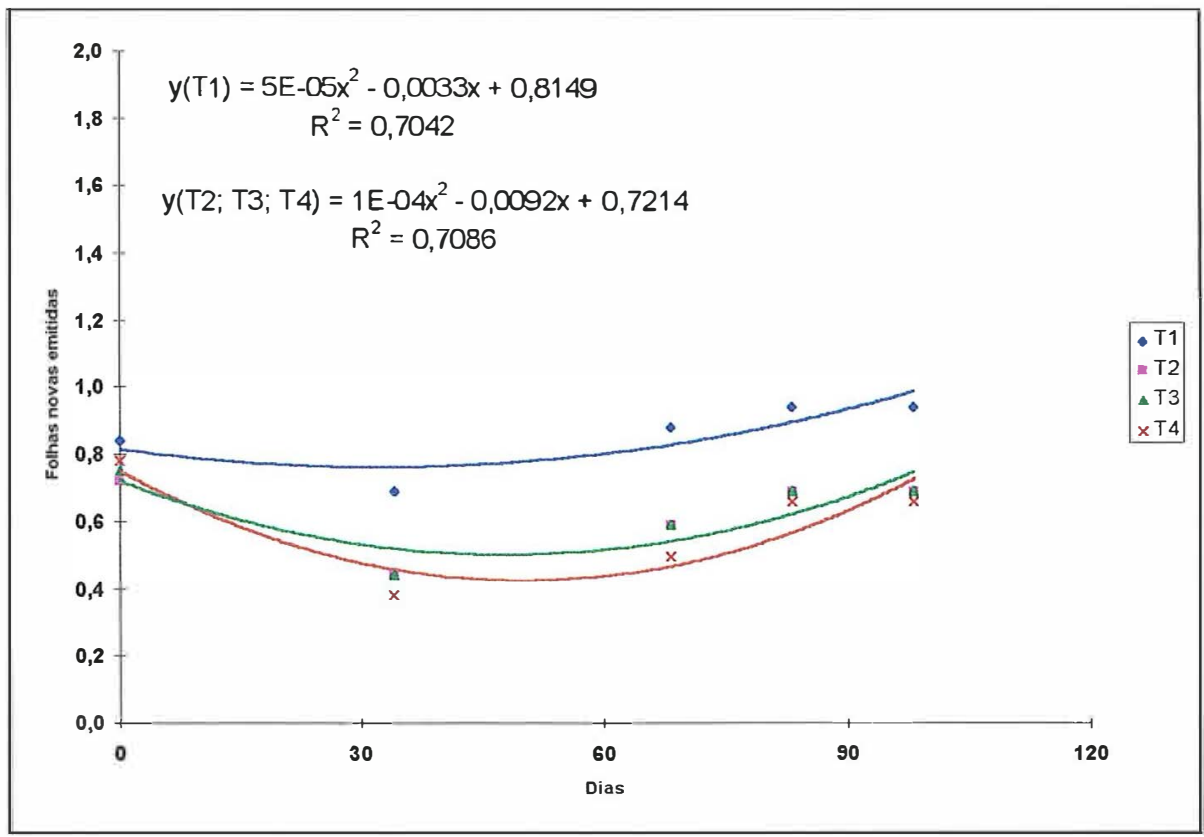

Figura 20 - Curvas e equações de regressão entre número médio de folhas emitidas e o período de avaliação para o período irrigado. 


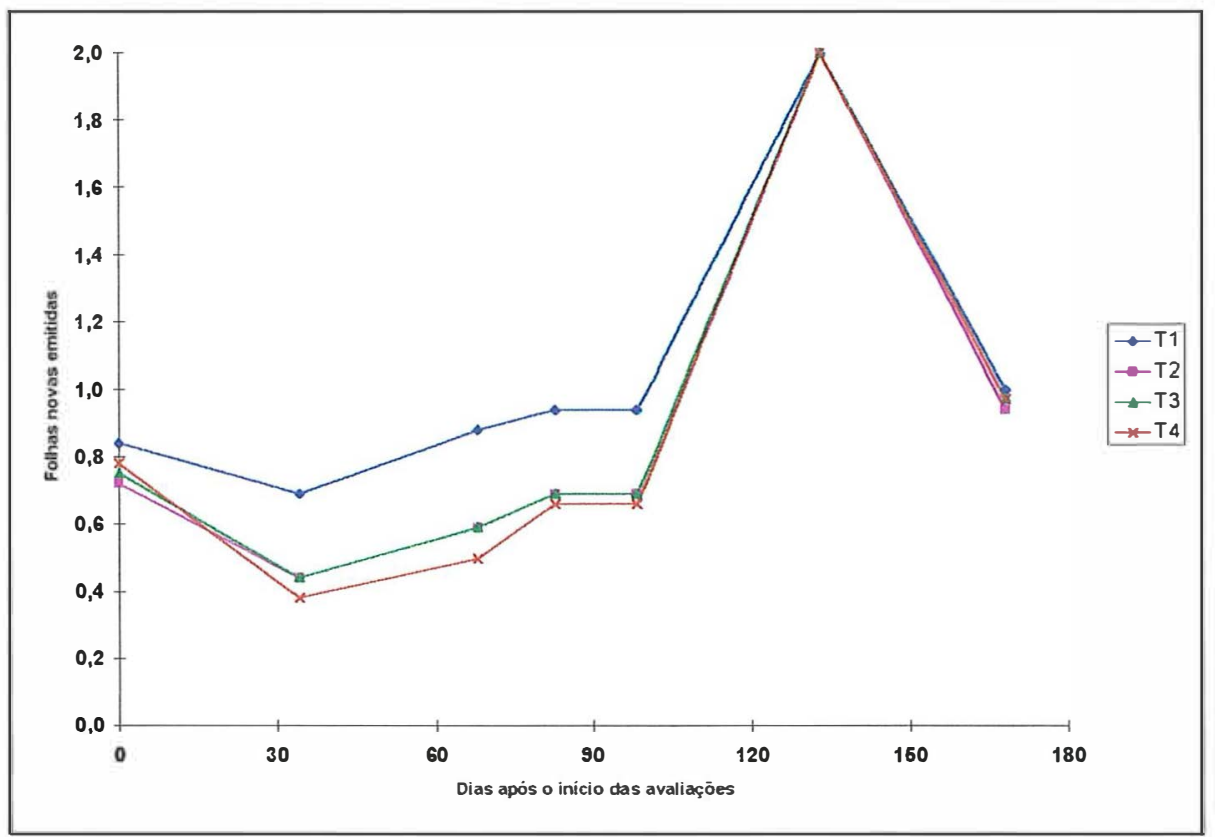

Figura 21 - Média do número de folhas novas emitidas em função do período de avaliação, para todos os períodos avaliado.

\subsection{Desenvolvimento Vegetativo da Pupunha}

No início do experimento.(31/07/97) as plantas apresentavam como dimensões médias: diâmetro na região do colo $11,42 \mathrm{~cm}$, diâmetro a $50 \mathrm{~cm}$ do colo $6,61 \mathrm{~cm}$, comprimento de ráquis $132 \mathrm{~cm}$, altura $115 \mathrm{~cm}$, com número médio de 8 perfilhos e 5 folhas. Ao final (16/01/98) suas dimensões foram: 14,32 cm de diâmetro no colo, 10,01 $\mathrm{cm}$ de diâmetro a $50 \mathrm{~cm}$ do colo, $162,35 \mathrm{~cm}$ de comprimento de ráquis, $180,88 \mathrm{~cm}$ de altura, número médio de 9 perfilhos e 8 folhas por planta.

Como resultado dos períodos de avaliação as plantas apresentaram médias de crescimento em diâmetro no colo e a $50 \mathrm{~cm}$ deste, comprimento de ráquis e altura de 0,5 ; 0,$6 ; 2,4 ; 8,5 \mathrm{~cm}$ respectivamente, apresentando ainda acréscimo médio de um perfilho e emissão de uma folha nova a cada período de avaliação, isso tanto para as avaliações realizadas aos 15 como aos 34 dias.

Para as duas últimas avaliações realizadas nos períodos de 17/12/97 e 16/01/98 (sem irrigação), as médias de acréscimos foram bem próximas aos valores observados 
para os periodos com irrigação e isto deve ter ocorrido pelo aumento da precipitação, temperatura e umidade relativa do ar nos meses de novembro $\left(244,30 \mathrm{~mm} ; 24^{\circ} \mathrm{C}\right.$ e $82 \%$ Figura 4) e dezembro $\left(191,10 \mathrm{~mm} ; 25^{\circ} \mathrm{C}\right.$ e $81 \%$ - Figura 4$)$.

\subsection{Balanço Hídrico no Solo}

A partir dos dados de potencial matricial e gradiente total da água no solo, foram calculados os valores de drenagem profunda e armazenamento de água no solo. Utilizouse a curva de retenção ajustada pelo modelo Van Genuchten (1980) para o cálculo da umidade volumétrica e a metodologia segundo Libardi et al. (1980) utilizada por Costa (1986) para a determinação da condutividade hidráulica do solo e posteriormente da drenagem profunda.

A evapotranspiração da cultura foi obtida segundo a equação geral de conservação das massas (equação 8)

O balanço de água no solo foi realizado de $01 / 08$ a 13/1 1/97, com variação dos dias por período, devido às irrigações e chuvas freqüentes, para os diferentes tratamentos. Nas Tabelas 13, 14, 15 e 16 onde encontram-se os termos do balanço hídrico, respectivamente, para os tratamentos $25,50,75 \% \mathrm{AD}$ e testemunha verifica-se que houveram diferenças de variações no armazenamento de água no solo.

Os maiores valores de irrigação obtidos para o tratamento 1(25\% AD) (Tabela 14), ocorreram principalmente no mês de agosto (do $1 .^{\circ}$ ao $4 .^{\circ}$ período) que teve baixo índice de precipitação pluviométrica (apenas $17,3 \mathrm{~mm}$ ). Já no mês de setembro (do $5 .^{\circ}$ ao $9 .^{\circ}$ periodo), houve uma maior variação desses resultados, pois ocorreram precipitações ao longo dos períodos estudados, não necessitando de irrigação, isto principalmente nos períodos 7,8 e 9 , onde o consumo tende a ser próximo para todos os tratamentos $(E t c=4,9,2,3$ e 4,5 mm), com exceção da testemunha . No mês de outubro, os valores de evapotranspiração da cultura para o tratamento 1 foram superiores aos demais tratamentos, com exceção do $10{ }^{\circ}$ e $11 .^{\circ}$ periodos.

Apesar de terem ocorrido variações nos valores de evapotranspiração da cultura entre os tratamentos 1 e 2 (Tabelas 13 e 14) em todos periodos, seus valores totais são 
semelhantes $(E T c=282$ e $276 \mathrm{~mm})$. Os totais de variação de armazenamento também foram bem próximos entre estes tratamentos. $(\Delta \operatorname{Arm} .=13,9$ e $13,3 \mathrm{~mm})$ e isto ocorreu porque o tratamento 1 recebeu apenas $14 \mathrm{~mm}$ a mais que o tratamento 2 por ter menor turno de rega.

Tabela 13 - Componentes do balanço de água no solo, precipitação (P), irrigação (I), drenagem ou ascensão capilar (D/AC), variação de armazenamento ( $\triangle$ Arm), evapotranspiração da cultura (ETc) e evapotranspiração de referência (ETo), realizado para o Tratamento $1(25 \% \mathrm{AD})$.

\begin{tabular}{lccccccc}
\hline \multicolumn{1}{c}{ Período } & $\begin{array}{c}\mathrm{P} \\
(\mathrm{mm})\end{array}$ & $\begin{array}{c}\mathrm{I} \\
(\mathrm{mm})\end{array}$ & $\begin{array}{c}\mathrm{D} / \mathrm{AC} \\
(\mathrm{mm})\end{array}$ & $\begin{array}{c}\Delta \text { Arm } \\
(\mathrm{mm})\end{array}$ & $\begin{array}{c}\text { ETc } \\
(\mathrm{mm} / \mathrm{dia})\end{array}$ & $\begin{array}{c}\text { ETo } \\
(\mathrm{mm} / \mathrm{dia})\end{array}$ & $\begin{array}{c}\text { Kc médio } \\
\text { do periodo }\end{array}$ \\
\hline 1) $01-09 / 08$ & 0 & 14 & $-0,41$ & $-3,4$ & 1,9 & 1,9 & 1,00 \\
2) $10-17 / 08$ & 0 & 14 & $-0,18$ & 3,7 & 1,3 & 2,0 & 0,65 \\
3)18-25/08 & 17,3 & 14 & $-0,56$ & 2,5 & 3,5 & 3,5 & 1,00 \\
4)26/08-02/09 & 0 & 17 & $-0,27$ & $-4,1$ & 2,6 & 3,5 & 0,74 \\
5)03-09/09 & 2,4 & 17 & $-0,37$ & 1,4 & 2,5 & 3,0 & 0,83 \\
6)10-17/09 & 27,4 & 8,5 & $-0,32$ & 11,8 & 2,9 & 4,5 & 0,64 \\
7) 18-22/09 & 28 & 0 & $-0,28$ & 3,5 & 4,9 & 3,3 & 1,48 \\
8)23-26/09 & 12,5 & 0 & $-0,31$ & 2,9 & 2,3 & 3,0 & 0,76 \\
9)27/09-04/10 & 32,3 & 0 & $-0,46$ & $-3,9$ & 4,5 & 4,0 & 1,12 \\
10)5-13/10 & 6 & 17 & $-0,18$ & 0,9 & 2,4 & 4,3 & 0,56 \\
11)14-22/10 & 29 & 8,5 & $-0,45$ & $-3,3$ & 4,5 & 4,4 & 1,02 \\
12)23-31/10 & 13 & 17 & 0,03 & 1,4 & 3,2 & 4,3 & 0,74 \\
13)1-8/11 & 32 & 17 & $-0,34$ & 1,9 & 5,8 & 4,3 & 1,35 \\
\hline Total & 199,9 & 144 & $-3,9$ & 13,9 & 281,7 & 306,34 & \\
\hline
\end{tabular}


Tabela 14 - Componentes do balanço de água no solo, precipitação (P), irrigação (I), drenagem ou ascensão capilar (D/AC), variação de armazenamento $(\Delta$ Arm), evapotranspiração da cultura (ETc) e evapotranspiração de referência (ETo), realizado para o Tratamento $2(50 \% \mathrm{AD})$.

\begin{tabular}{lcccccc}
\hline \multicolumn{1}{c}{ Periodo } & $\begin{array}{c}\mathrm{P} \\
(\mathrm{mm})\end{array}$ & $\begin{array}{c}\mathrm{I} \\
(\mathrm{mm})\end{array}$ & $\begin{array}{c}\mathrm{D} / \mathrm{AC} \\
(\mathrm{mm})\end{array}$ & $\begin{array}{r}\Delta \text { Arm } \\
(\mathrm{mm})\end{array}$ & $\begin{array}{c}\text { ETc. } \\
(\mathrm{mm} / \mathrm{dia})\end{array}$ & $\begin{array}{c}\text { ETo } \\
(\mathrm{mm} / \mathrm{dia})\end{array}$ \\
\hline 1) $01-09 / 08$ & 0 & 0 & $-0,17$ & $-12,40$ & 1,4 & 1,9 \\
2)10-17/08 & 0 & 28 & $-0,07$ & 12,54 & 2,0 & 2,0 \\
3)18-25/08 & 17,3 & 0 & 0,06 & $-7,20$ & 3,1 & 3,5 \\
4)26/08-02/09 & 0 & 17 & 0,01 & 8,59 & 1,1 & 3,5 \\
5)03-09/09 & 2,4 & 17 & $-0,37$ & $-4,80$ & 3,4 & 3,0 \\
6)10-17/09 & 27,4 & 17 & $-0,32$ & 12,21 & 4,0 & 4,5 \\
7)18-22/09 & 28 & 0 & $-0,28$ & 3,72 & 4,8 & 3,3 \\
8)23-26/09 & 12,5 & 0 & $-0,31$ & 2,94 & 2,3 & 3,0 \\
9)27/09-04/10 & 32,3 & 0 & $-0,51$ & $-2,78$ & 4,3 & 4,0 \\
10)5-13/10 & 6 & 17 & $-0,26$ & 0,62 & 2,5 & 4,3 \\
11)14-22/10 & 29 & 17 & $-0,39$ & 11,5 & 4,0 & 4,4 \\
12)23-31/10 & 13 & 0 & 0,03 & $-14,0$ & 3,0 & 4,3 \\
13)1-8/11 & 32 & 17 & 0,02 & 2,4 & 5,8 & 4,3 \\
\hline Total & 199,9 & 130 & $-2,6$ & 13,3 & 275,8 & 306,34 \\
\hline
\end{tabular}

O balanço hídrico realizado para o tratamento 3 (75\% AD) (Tabela 15), apresentou em alguns períodos, valores de evapotranspiração da cultura maiores que os obtidos para o tratamento 1 , e em outros, para o tratamento 2, porém, nos períodos 10 e 11 esses valores foram superiores aos obtidos para os tratamentos 1 e 2 , o que pode ter ocorrido em função das maiores lâminas de irrigação que foram fornecidas para o tratamento 3. O valor total da evapotranspiração da cultura obtido para este tratamento foi semelhante aos tratamentos 1 e $2(E T c=41,5 \mathrm{~mm})$, porém, com maior valor total de variação no armazenamento $(\Delta \operatorname{Arm} .=17,3 \mathrm{~mm})$.

Já no tratamento 4 (Testemunha) (Tabela 16), os valores de evapotranspiração da cultura $(\mathrm{mm} / \mathrm{dia})$ foram de uma maneira geral, inferiores aos valores determinados para os demais tratamentos, assim como os valores totais de evapotranspiração e variação de armazenamento $(\mathrm{ETc}=28,1 \mathrm{~mm}$ e $\Delta \mathrm{Arm} .=-2,7)$ que foi negativa por não ter recebido irrigação, a entrada de água no solo ocorreu apenas por precipitação. 
Tabela 15 - Componentes do balanço de água no solo, precipitação (P), irrigação (I), drenagem ou ascensão capilar (D/AC), variação de armazenamento $(\triangle \mathrm{Arm})$, evapotranspiração da cultura (ETc) e evapotranspiração de referência (ETo), de água no solo realizado para a o tratamento 3 (75\% $\mathrm{AD})$.

\begin{tabular}{lcccccc}
\hline \multicolumn{1}{c}{ Período } & $\begin{array}{c}\mathrm{P} \\
(\mathrm{mm})\end{array}$ & $\begin{array}{c}\mathrm{I} \\
(\mathrm{mm})\end{array}$ & $\begin{array}{c}\mathrm{D} / \mathrm{AC} \\
(\mathrm{mm})\end{array}$ & $\begin{array}{c}\Delta \text { Arm } \\
(\mathrm{mm})\end{array}$ & $\begin{array}{c}\text { ETc } \\
(\mathrm{mm} / \mathrm{dia})\end{array}$ & $\begin{array}{c}\text { ETo } \\
(\mathrm{mm} / \mathrm{dia})\end{array}$ \\
\hline 1) $01-09 / 08$ & 0 & 0 & $-1,22$ & $-9,8$ & 1,0 & 1,9 \\
2)10-17/08 & 0 & 0 & $-0,17$ & $-13,3$ & 1,8 & 2,0 \\
3)18-25/08 & 17,3 & 42 & $-1,62$ & 33,4 & 3,0 & 3,5 \\
4)26/08-02/09 & 0 & 0 & $-1,01$ & $-14,9$ & 1,7 & 3,5 \\
5)03-09/09 & 2,5 & 25,5 & $-1,28$ & 7,13 & 2,8 & 3,0 \\
6)10-17/09 & 27,4 & 25,5 & $-1,46$ & 11,9 & 4,9 & 4,5 \\
7)18-22/09 & 28 & 0 & $-0,76$ & 3,0 & 4,8 & 3,3 \\
8)23-26/09 & 12,5 & 0 & $-0,62$ & 3,1 & 2,2 & 3,0 \\
9)27/09-4/10 & 32,3 & 0 & $-0,78$ & $-1,6$ & 4,1 & 4,0 \\
10)5-13/10 & 6 & 25,5 & $-0,55$ & $-0,2$ & 3,5 & 4,3 \\
11)14-22/10 & 29 & 25,5 & $-0,14$ & 8,6 & 5,1 & 4,4 \\
12)23-31/10 & 13 & 0 & 0,29 & $-10,9$ & 2,6 & 4,3 \\
13)1-8/11 & 32 & 0 & $-0,01$ & 0,9 & 4,0 & 4,3 \\
\hline Total & 199,9 & 142 & $-9,4$ & 17,3 & 276,7 & 306,43 \\
\hline
\end{tabular}

Tabela 16 - Componentes do balanço de água no solo, precipitação (P), irrigação (I), drenagem ou ascensão capilar (D/AC), variação de armazenamento $(\triangle \mathrm{Arm})$, evapotranspiração da cultura (ETc) e evapotranspiração de referência (ETo), de água no solo realizado para o Tratamento 4 (Testemunha).

\begin{tabular}{lcccccc}
\hline \multicolumn{1}{c}{ Período } & $\begin{array}{c}\mathrm{P} \\
(\mathrm{mm})\end{array}$ & $\begin{array}{c}\mathrm{I} \\
(\mathrm{mm})\end{array}$ & $\begin{array}{c}\mathrm{D} / \mathrm{AC} \\
(\mathrm{mm})\end{array}$ & $\begin{array}{c}\Delta \text { Arm } \\
(\mathrm{mm})\end{array}$ & $\begin{array}{c}\text { ETc } \\
(\mathrm{mm} / \mathrm{dia})\end{array}$ & $\begin{array}{c}\text { ETo } \\
(\mathrm{mm} / \mathrm{dia})\end{array}$ \\
\hline 1) $01-09 / 08$ & 0 & 0 & $-1,16$ & $-12,1$ & 1,2 & 1,9 \\
$2) 10-17 / 08$ & 0 & 0 & $-0,17$ & $-13,2$ & 1,6 & 2,0 \\
$3) 18-25 / 08$ & 17,3 & 0 & $-0,29$ & 8,4 & 1,1 & 3,5 \\
$4) 26 / 08-2 / 09$ & 0 & 0 & $-0,11$ & $-8,3$ & 1,0 & 3,5 \\
$5) 03-09 / 09$ & 2,4 & 0 & 0,02 & $-0,8$ & 0,5 & 3,0 \\
6)10-17/09 & 27.4 & 0 & $-0,11$ & 17,9 & 1,2 & 4,5 \\
7)18-22/09 & 28 & 0 & $-0,14$ & 4,1 & 4,2 & 3,3 \\
8)23-26/09 & 12,5 & 0 & $-0,19$ & 0,7 & 3,0 & 3,0 \\
9)27/10-4/11 & 32,6 & 0 & $-0,91$ & $-2,9$ & 4,3 & 4,0 \\
10)5-13/10 & 6 & 0 & $-0,50$ & $-10,3$ & 1,8 & 4,3 \\
11)14-22/10 & 29 & 0 & $-0,15$ & 6,8 & 2,5 & 4,4 \\
12)23-31/10 & 13 & 0 & $-0,25$ & 4,9 & 2,0 & 4,3 \\
13)1-8/11 & 32 & 0 & $-0,07$ & 2,1 & 3,7 & 4,3 \\
\hline Total & 199,9 & 0 & $-4,1$ & $-2,7$ & 179,1 & 306,43 \\
\hline
\end{tabular}


Nos tratamentos 1, 2, 3 e 4 (Figura 22), os valores de evapotranspiração de referência medidos pelo par de lisímetros foram de maneira geral, superiores aos valores de evapotranspiração da cultura calculada pelo método do balanço hídrico, sendo superiores, somente nos períodos 7 e 9 em todos os tratamentos, com exceção em outros períodos diferentes para cada tratamento.

O tratamento 1 (25\% AD) (Tabela 13) foi o que apresentou valores de evapotranspiração da cultura igual aos valores de evapotranspiração de referência em um maior número de períodos $\left(1 .^{\circ}, 3 .^{\circ}\right.$ e $\left.11 .^{\circ}\right)$, quando comparado aos demais tratamentos.

O tratamento 4 (Testemunha) (Figura 22) apresentou valores de evapotranspiração da cultura, na maıror parte dos períodos, inferiores à evapotranspiração de referência, pelo déficit hídrico em função da ausência de irrigação.

Os valores de coeficiente de cultivo $(\mathrm{Kc})$ determinados para os meses de realização do balanço hídrico variaram de 0,56 à 1,35 , sendo que o valor médio de $\mathrm{Kc}$ obtido para o tratamento $1,(\mathrm{Kc}=0,92)$ (Tabela 13), foi maior que o valore médio encontrado por $(\mathrm{Kc}=0,85)$, para a cultura do côco (Cocos micifera).

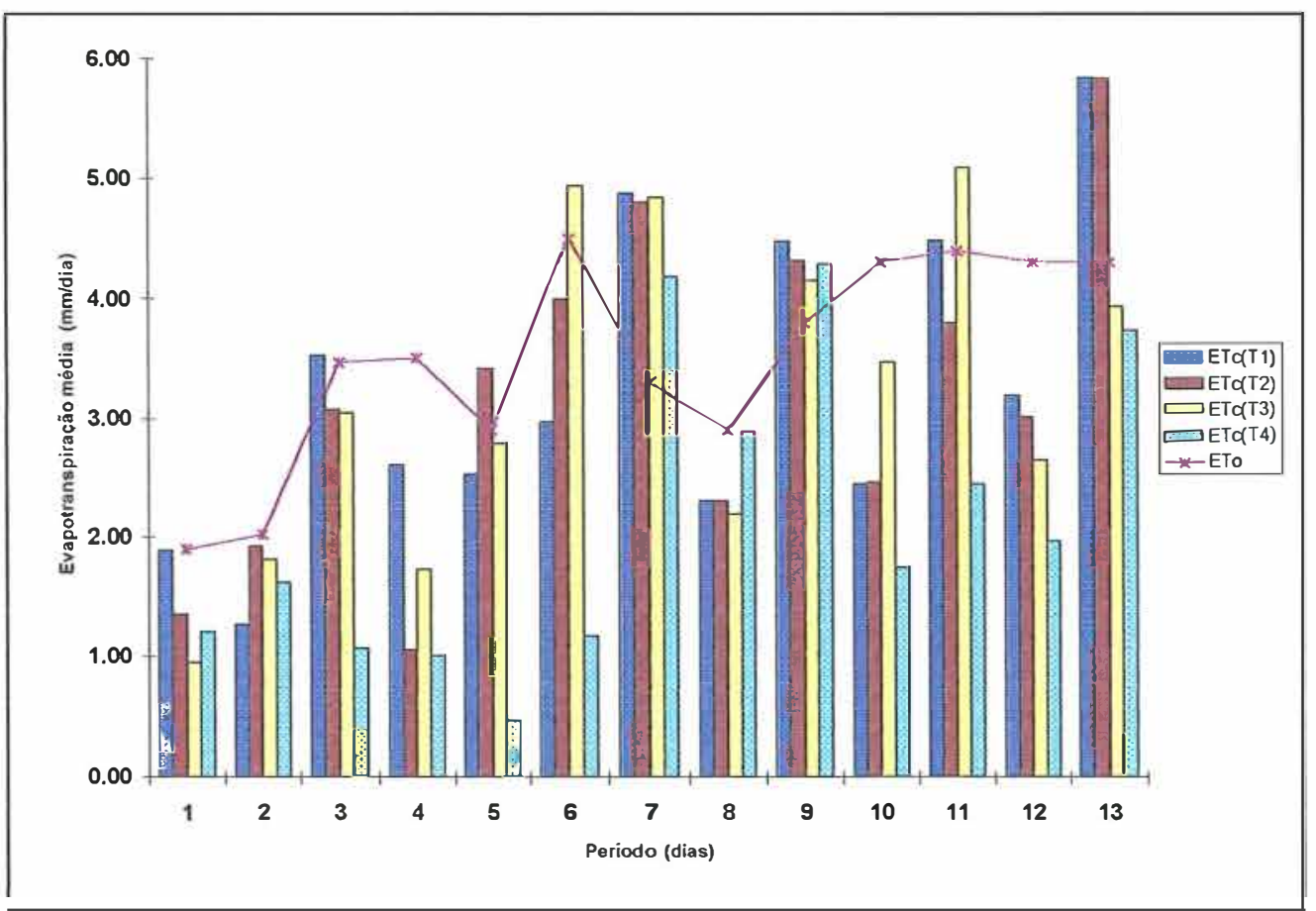

Figura 22 - Evapotranspiração média da cultura e de referência para cada período, para os Tratamentos 1, 2, 3 e 4 . 


\subsubsection{Consumo de Água pela Cultura}

Durante o período de realização do balanço hídrico, foi feito um estudo de variação de armazenamento de água para cada camada do solo estudada, com a finalidade de verificar qual a camada em que ocorre o maior consumo de água.

Verifica-se pela Tabela 17 que para as profundidades de $40-60 \mathrm{~cm}$ e de $60-80$ $\mathrm{cm}$ a variação de armazenamento de água era muito baixa e que mais de $80 \%$ da variação de armazenamento ocorre na camada de 0 - $40 \mathrm{~cm}$ (Figura 23). Ferreira et al. (1980), afirma que $58 \%$ do total de massa radicular se localiza nos primeiro $20 \mathrm{~cm}$ do solo, isso para um solo tipo Latossolo Amarelo, textura média. Segundo Morales \& Vargas (1990), o sistema radicular da cultura é bem superficial, com $74 \%$ das raizes distribuidas em um raio e profundidade de $40 \mathrm{~cm}$.

Tabela 17 - Variação de armazenamento acumulado nas camadas de 0 - 20, 20 - 40, 40 -

60 e $60-80 \mathrm{~cm}$, em função da profundidade de instalação do tensiômetro no solo.

\begin{tabular}{ccc}
\hline Camada do solo $(\mathrm{cm})$ & $\begin{array}{c}\text { Profundidade de instalação dos } \\
\text { tensiômetros }(\mathrm{cm})\end{array}$ & $\begin{array}{c}\text { Variação de Armazenamento } \\
\text { Acumulado (\%) }\end{array}$ \\
\hline $0-20$ & 10 & 52,5 \\
$20-40$ & 30 & 23,31 \\
$40-60$ & 50 & 12,74 \\
$60-80$ & 70 & 11,55 \\
\hline
\end{tabular}

A Figura 23 representa a variação de armazenamento acumulada média de todos os tratamentos, cujas profundidades correspondem as profundidades de instalação dos tensiômetros.

Durante o desenvolvimento da cultura, no período de realização do experimento, a água foi retirada principalmente da camada de $0-40 \mathrm{~cm}$, com pouca variação da umidade volumétrica nas profundidades de 50 e $70 \mathrm{~cm}$, como demonstra o perfil de umidade na Figura 24. 


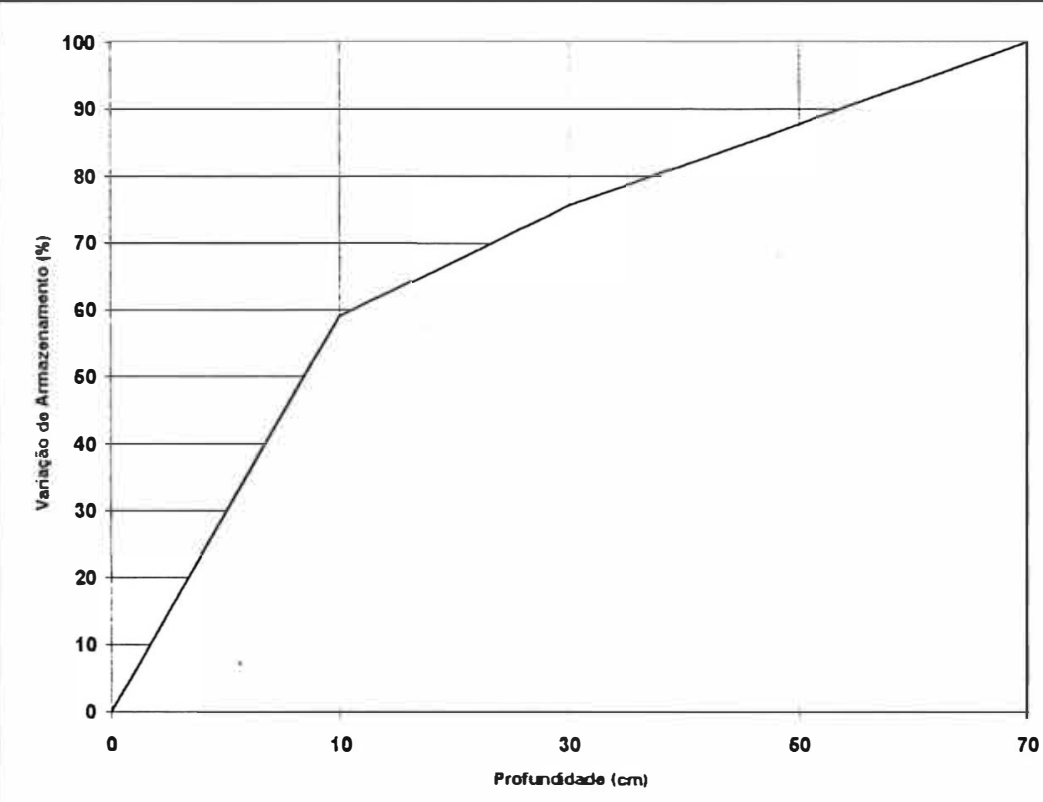

Figura 23 - Variação do armazenamento de água (\%) em função da profundidade do solo.

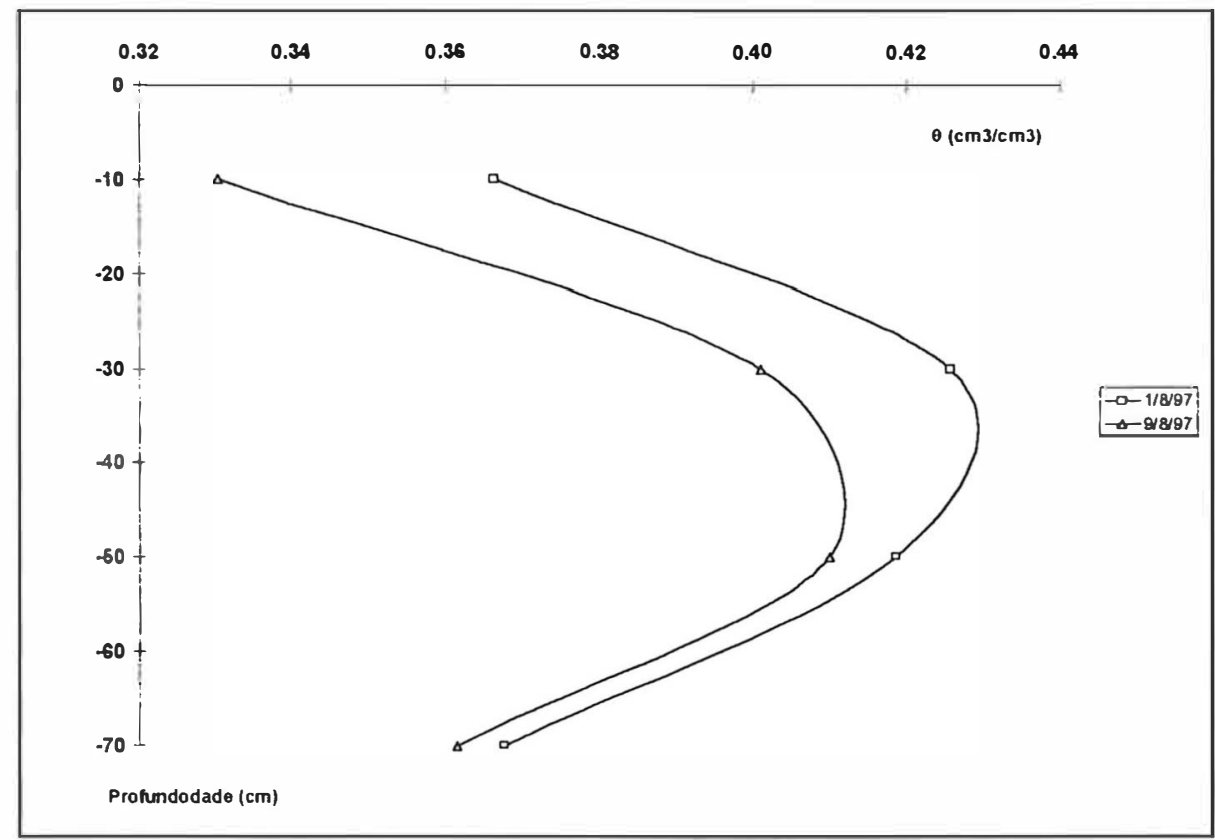

Figura 24 - Perfil de umidade do solo no primeiro período de realização do balanço hídrico. 


\section{CONCLUSÕES}

1) Houve diferença significartiva entre os tratamentos para as variáveis diâmetro no colo, altura e folhas novas emitidas, sendo que para as duas primeiras variáveis, as médias de crescimento do Tatamento 1 ( $25 \%$ AD), foram superiores apenas a do Tratamento 4, enquanto que para folhas novas emitidas, o Tratamento 1 foi superior aos Tratamentos T2 (50\% AD), T3 (75\% AD) e Testemunha.

2) Para todas as variáveis, os maiores acréscimos ocorreram a partir dos 68 dias após o início da imposição dos tratamentos e avaliações.

3) Os valores de coeficiente de cultivo $(\mathrm{Kc})$ determinados para os meses de realização do balanço hídrico variaram de 0,56 à 1,35 , sendo que o valor de Kc médio para os períodos obtido foi de 0,91 .

4) $80 \%$ da variação de armazenamento de água (consumo da cultura) ocorreu até a profundidade de $40 \mathrm{~cm}$, indicando que para as condições estudadas, a camada para manejo de irrigação deve ser de $0-40 \mathrm{~cm}$. 
ANEXO 


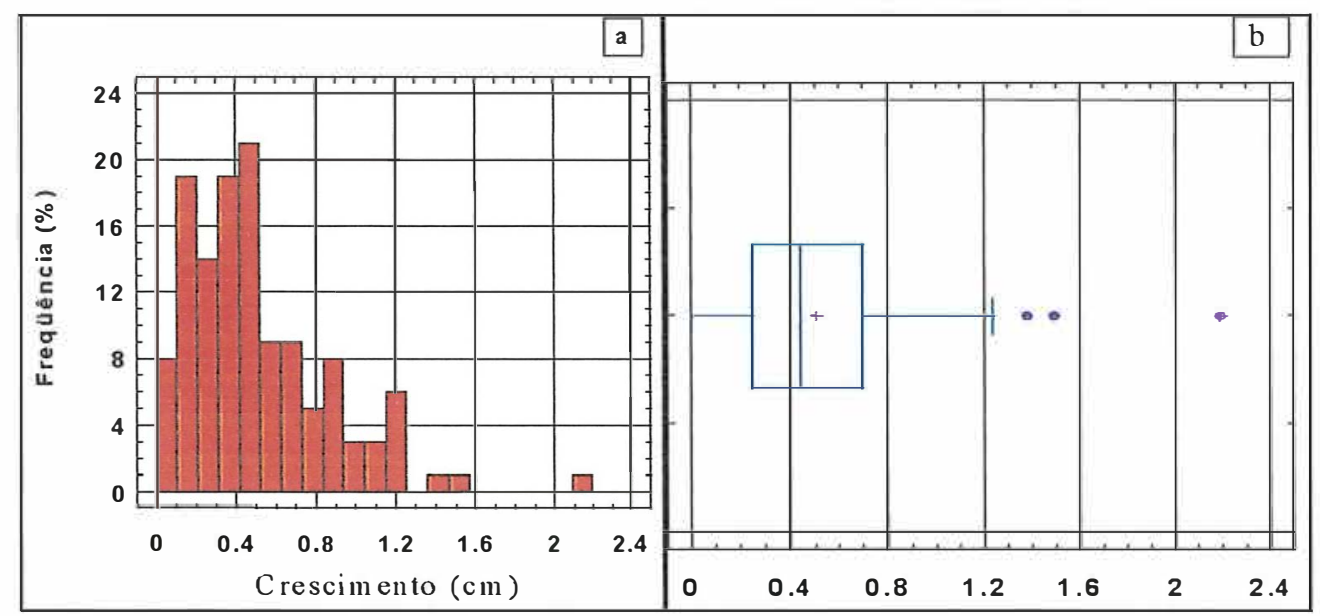

Figura 1 - Histograma de freqüência (a) e box-plot (b) para a variável diâmetro na região do colo da planta.

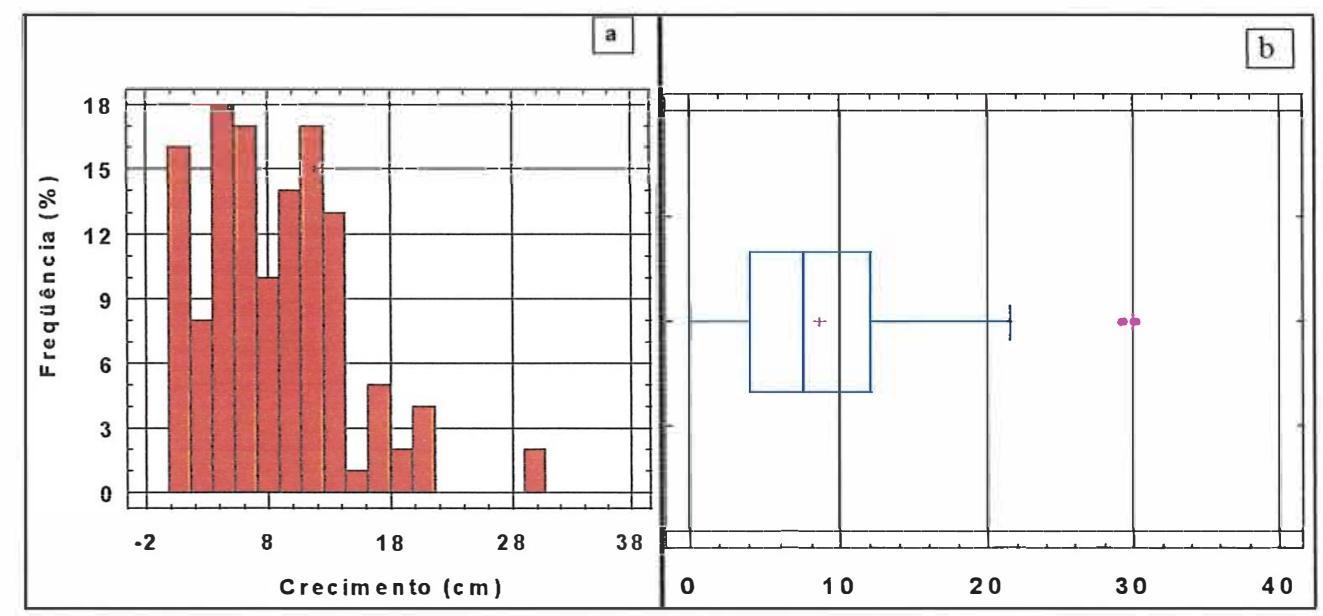

Figura 2 - Histograma de freqüência (a) e box-plot (b) para a variável altura.

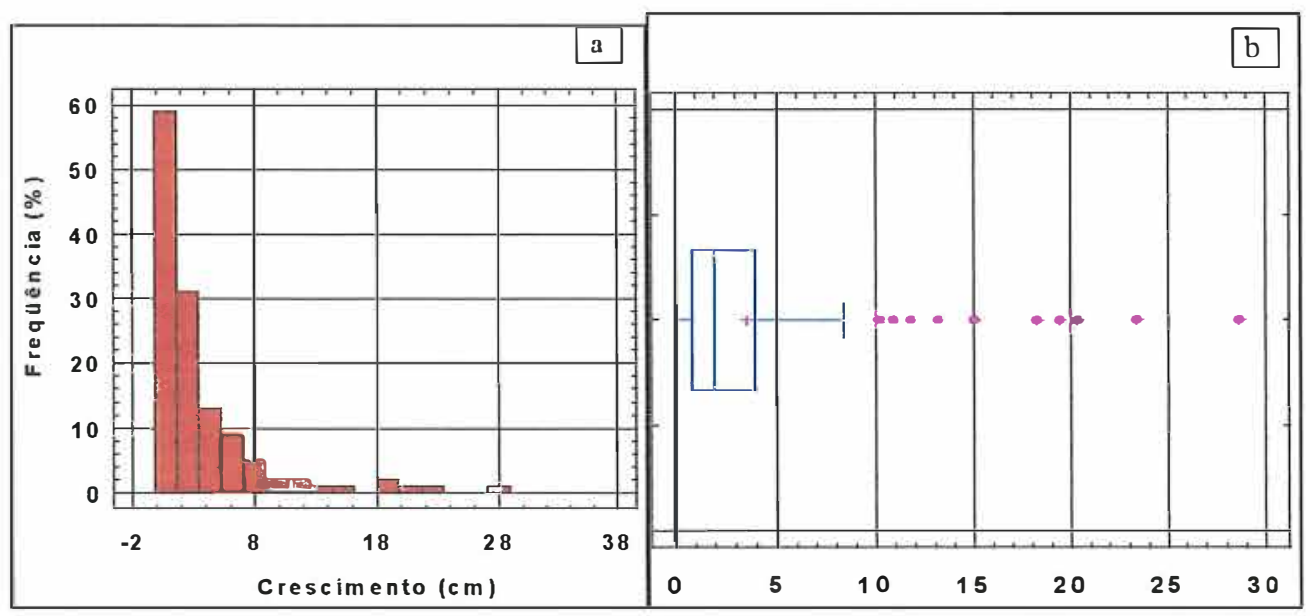

Figura 3 - Histograma de freqüência (a) e box-plot (b) para a variável comprimento de ráquis. 


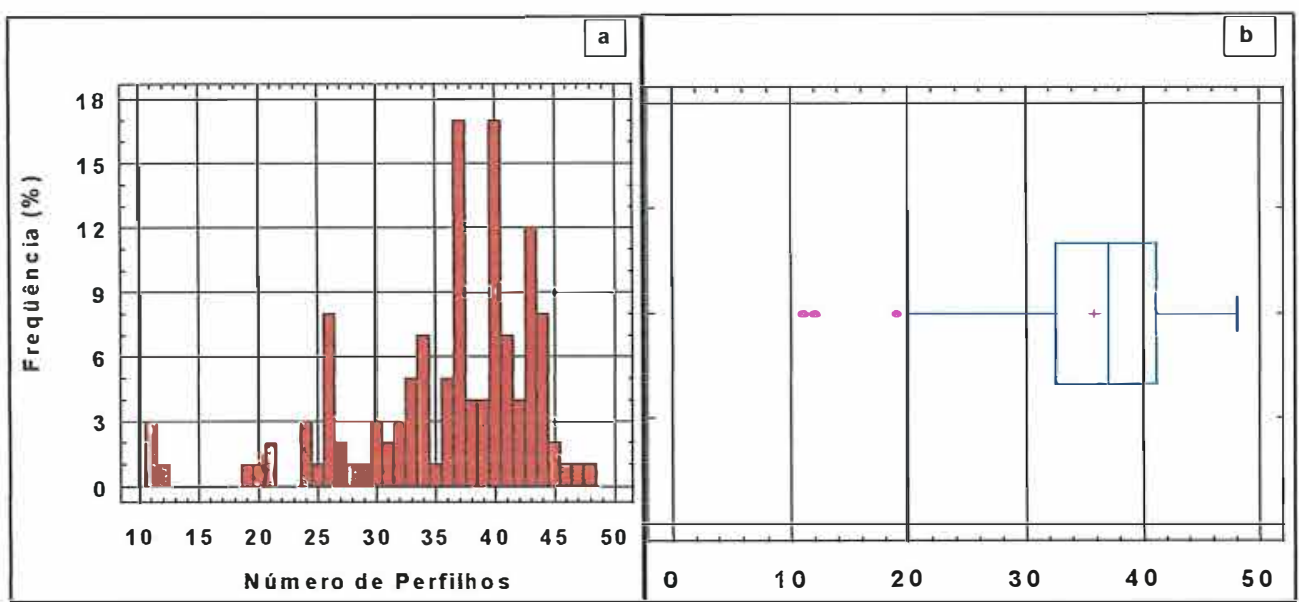

Figura 4 -Histograma de freqüência (a) e box-plot (b) para a variável numero de perfilhos.

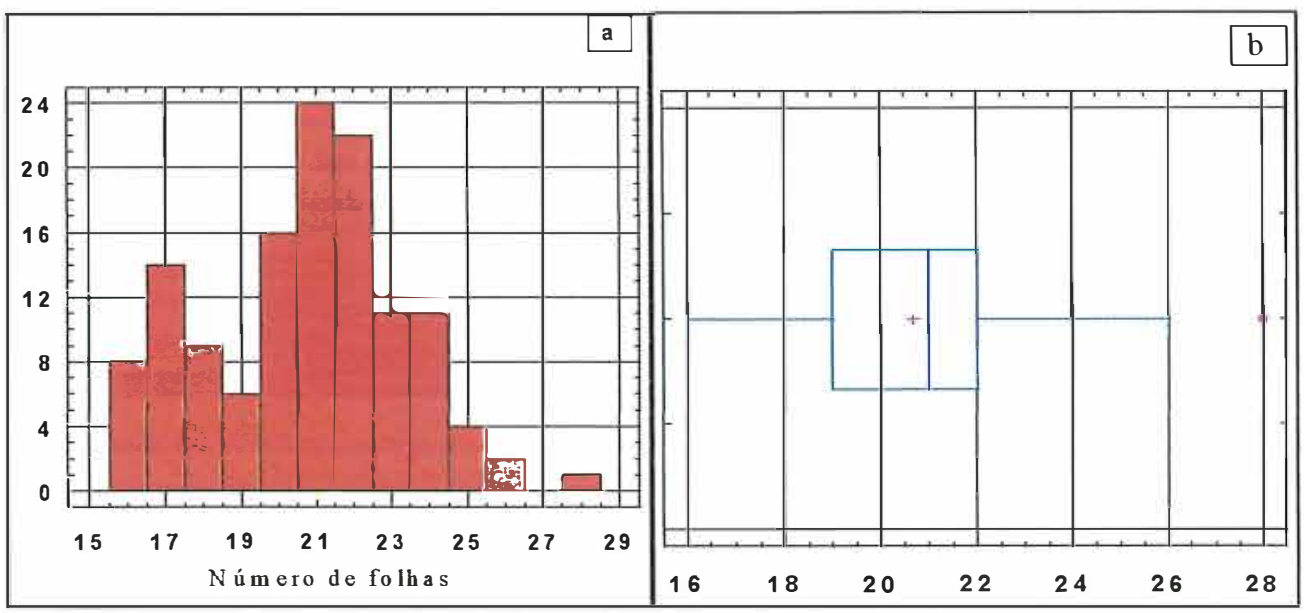

Figura 5 - Histograma de freqüência (a) e box-plot (b) para a variável número de folhas.

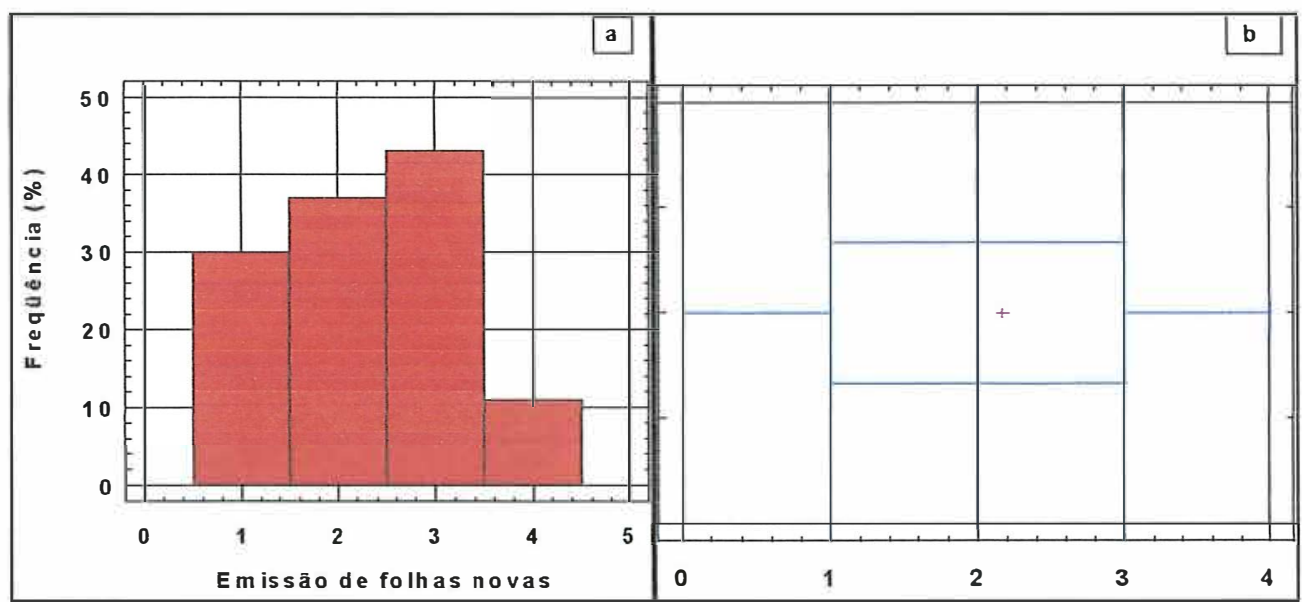

Figura 6 - Histograma de freqüência (a) e box-plot (b) para a variável emissão de folhas novas. 
Histograma de Distribuição de Freqüência para Dados Transformados

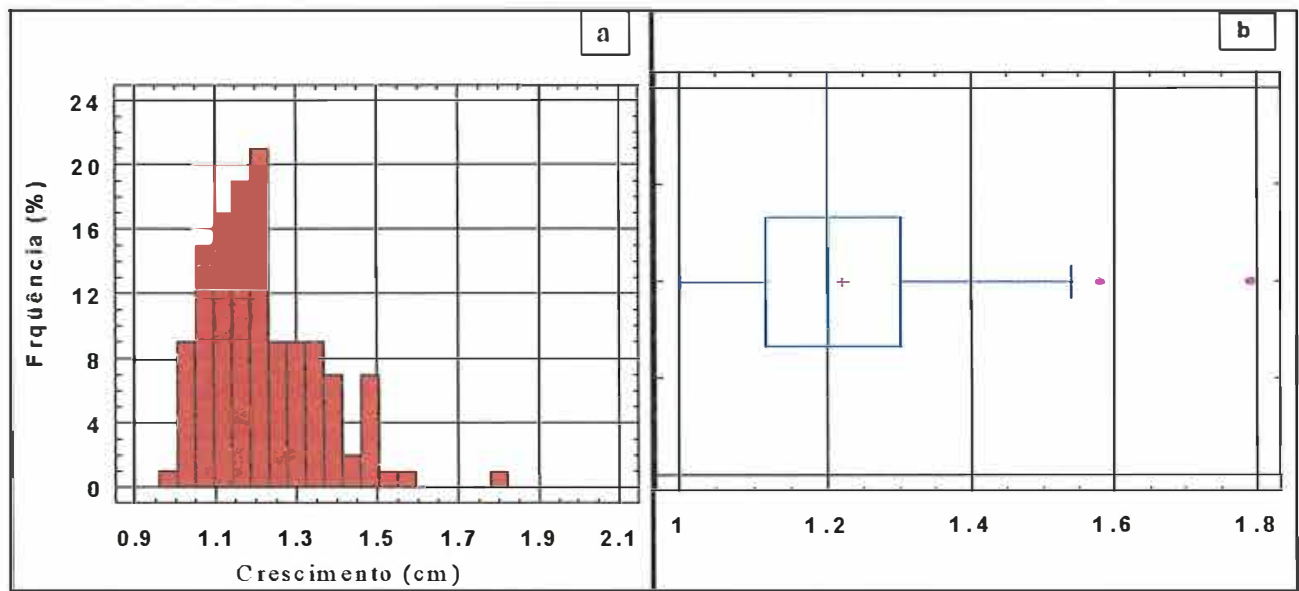

Figura 7 - Histograma de distribuição de frequiência (a) e box-plot (b) para a variável diâmetro no colo para dados transformados.

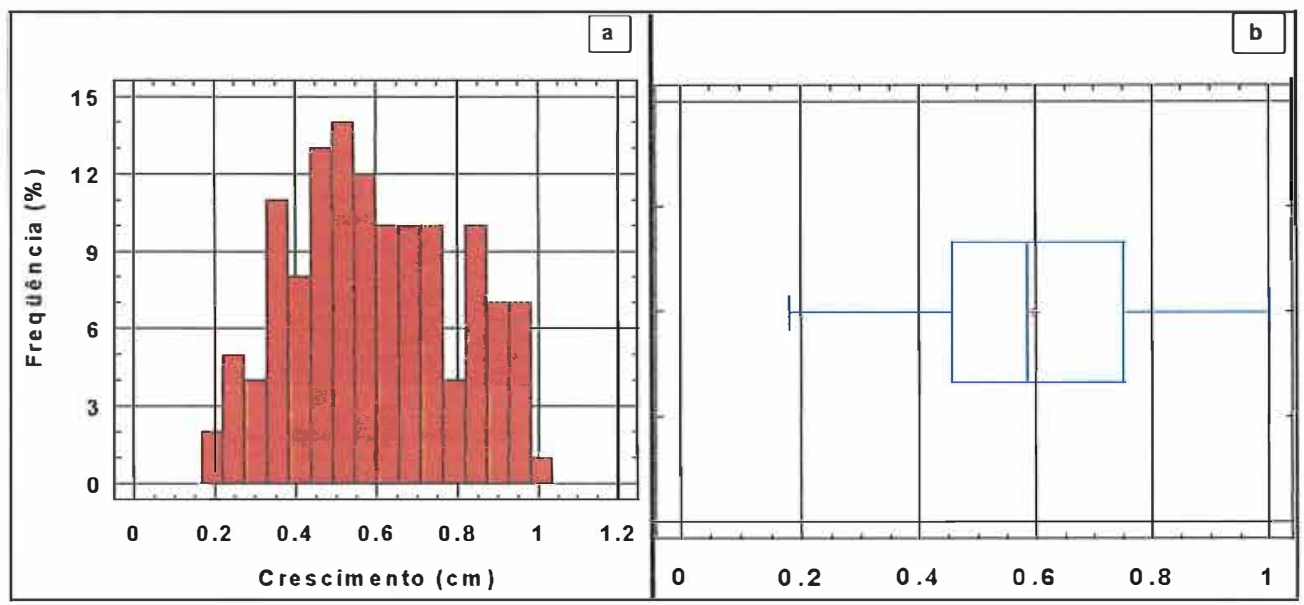

Figura 8 -Histograma de distribuição de freqüência (a) e box-plot (b) para a variável comprimento de ráquis para dados transformados.

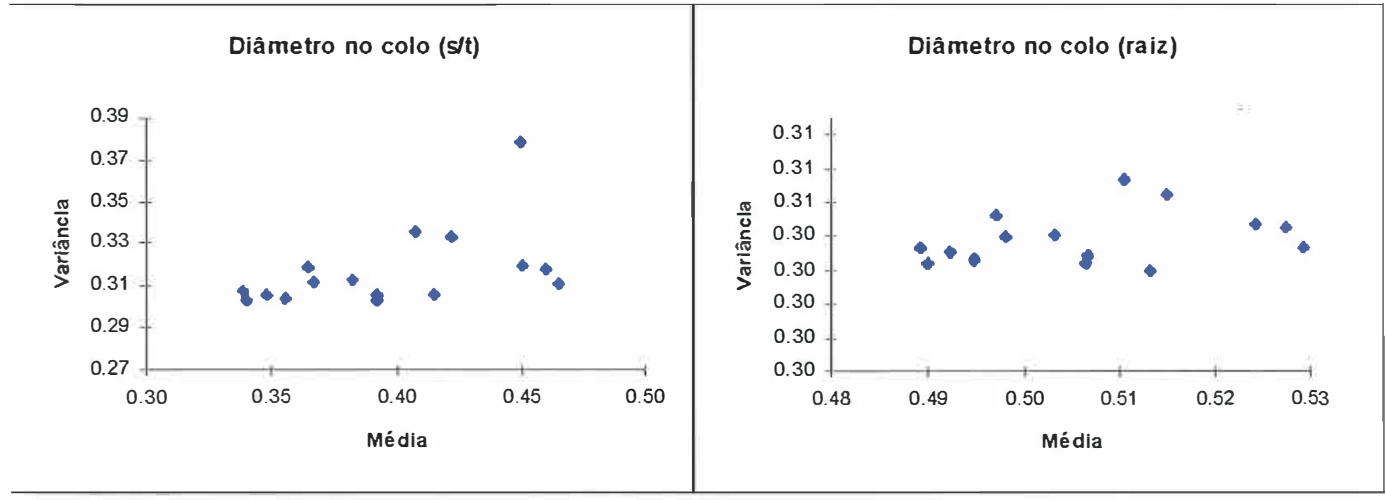

Figura 9 - Diagrama de dispersão do log da média versus log da variância, para a variável diâmetro no colo (dados sem transformação e transformados). 

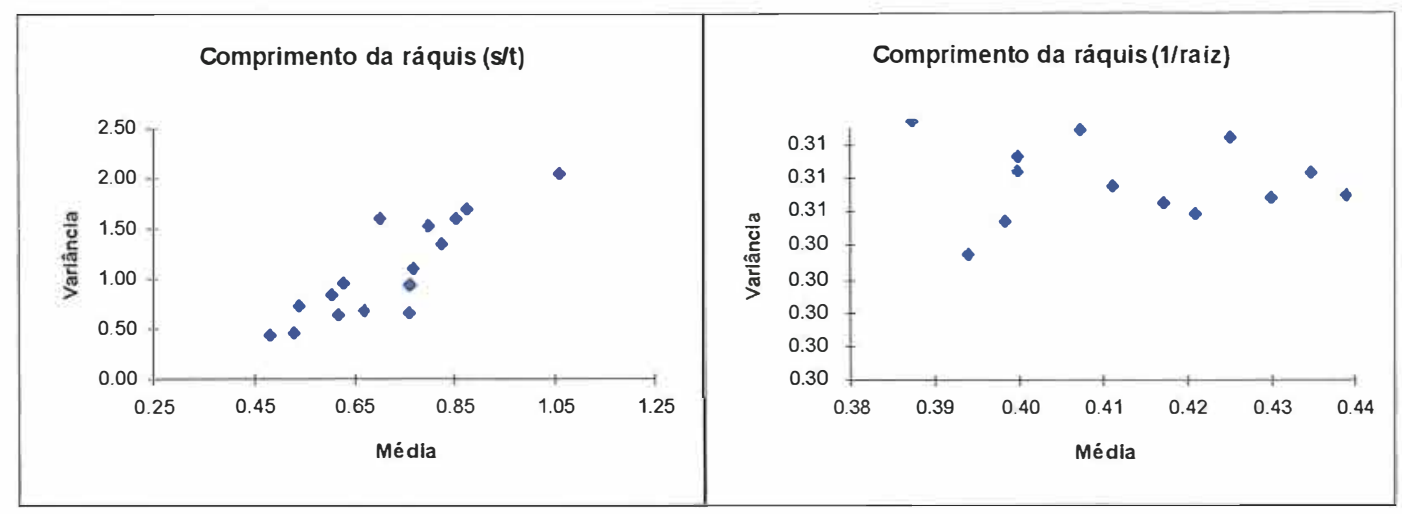

Figura 10 - Diagrama de dispersão do log da média versus log da variância, para a variável comprimento da ráquis (dados sem transformação e transformados).
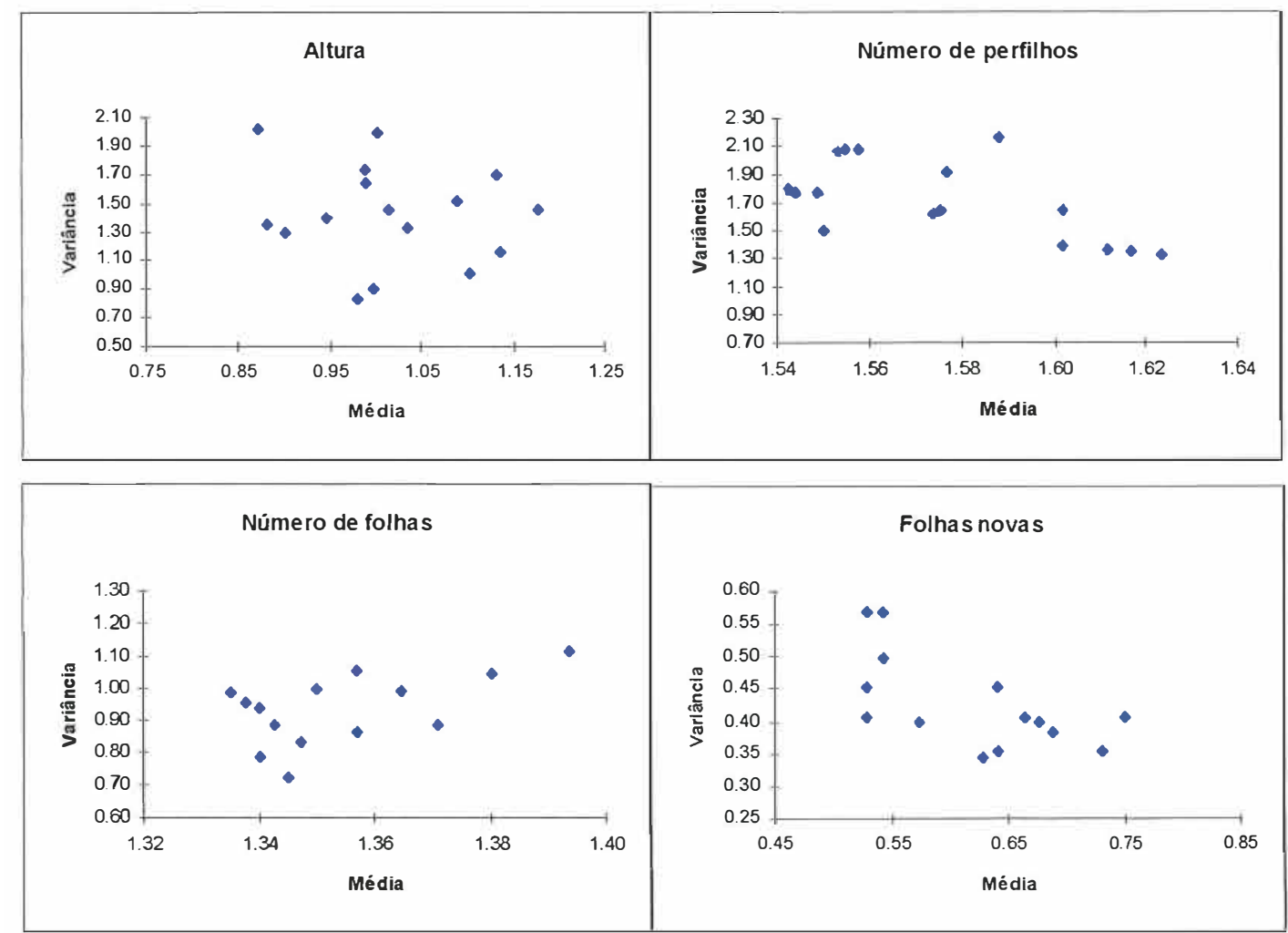

Figura 11 - Diagrama de dispersão do log da média versus log da variância, para as variáveis altura, número de perefilhos, número de follhas e emissão de follhas novas. 


\section{REFERENNCIAS BIBLIOGRAFICAS}

ALVES, M. I. F.; MACHADO, A. A.; ZONTA, E. P. Tópicos especiais de estatística experimental utilizando o SANEST (Sistema de Análise Estatística para Microcomputador). Porto Alegre: UFRS, 1993. 110p.

ARRUDA, F. B. Avaliação do desempenho das culturas. In: III CURSO PRÁTICO INTERNACIONAL DE AGROMETEOROLOGIA PARA OTIMIZAÇÃO DA IRRIGAÇÃO, Campina, 1989. 15p.

ATLAS PLUVIOMÉTRICO DE ESTADO DE SÃO PAULO : período 1941-1970. São Paulo, 1972. 84p.

BARBOSA, A. M. M. Pupunha (Bactris gasipaes) In: ENCONTRO SOBRE PRODUÇÃO DE PALMITO, Piracicaba, 1993. Piracicaba: CALQ, 1993. p.8-11.

BARRADA, Y. Water balance studies. In: FAO/UNDP REGIONAL SEMINAR ON EFFECTIVE USE OF IRRIGATION WATER AT THE FARM LEVEL, Damascus, 1971. Water uses. Rome: FAO, 1972. p. 60-90. (FAO. Irrigation and Drainage Paper, 13).

BENINCASA, M. M. P. Análise do crescimento de plantas noções básicas. Jaboticabal, FUNEP, 1988. 42p.(Boletim Técnico, 467a). 
BOVI, M. L. A. Palmito pupunha: informações básicas para o cultivo. In: FURIA. L.R.R Encontro sobre Produção de Palmito. Piracicaba, CALQ, 1993, p.12-33.

BOVI, M. L. A. Palmito pupunha. In: INSTITUTO AGRONÔMICO (Campinas). Instruções agrícolas para as principaic culturas econômicas. 6. ${ }^{a}$ ed., 1988, p. 269-271 (Bolateim Técnico, 200).

BURMAN, R. D.; NIXON, P. R.; WRIGTH, J. L.; et al. Water requirement. In: JENSEN, M. E. Desing and operation of farm irrigation system. St. Joseph: ASAE, 1980. cap. 6. p. 189-232.

CACEX - Carteira de comércio exterior - Banco do Brasil, 1990.

CAMACHO, V. E. El pejybay (Guilielma gasipaes (H.K.B.) Bailey), In: SIMPOSIO INTERNACIONAL SOBRE PLANTAS DE INTERESSE ECONÔMICO DE LA FLORA AMAZÔNICA, Turrialba: IICA, 1976. p.101-106.

CLEMENT, C. R. Pupunha uma árvore doemsticada. Ciência Hoje, v. 5 n.29, p. 42-49, 1987.

CLEMENT, C. R. Growth and analysis of pejibaye (Bactris gasipaes Kunth, Palmae) in Hawaii. Honolulu, 1995. 221 p. Thesis (Ph.D.) - University of Hawaii.

COSTA, A. C. S. Balanço hídrico das culturas de feijão (Phaseolus vulgaris L.) e de milho (Zea mays L.) sob condições de campo. Piracicaba, 1986. 166p. Dissertação (Mestrado) - Escola Superior de Agricultura "Luiz de Queiroz", Universidade de São Paulo.

DAKER, A. Irrigação e drenagem: a água na agricultura. 7. ed. Rio de Janeiro: Freitas Bastos, 1988. v.3. 535p. 
DOOREMBOS, J.; KASSAM, A. H. Yield response to water. Rome: FAO, 1979. 170p. (FAO. Irrigation and Drainage Paper, 33).

DOWNEY, L. A. Effect of gypsun and drought stress on maize (Zea mays L.). II. Consuptive use of water. Agronomy Journal. v.63, p.597-600, July/Aug. 1971.

DOWNEY, L. A. Water-yield relations for nonforage crops. Journal of Irrigation and Drainage Division, v 98., p 107-114, Mar. 1972.

FERREIRA, S. A. N.; CLEMENT, C. R.; RANZANI, S. S. C. Contribuição para o conhecimento do sistema radicular da pupunheira (Bactris gasipaes H.B.K., Guilielma gasipaes (H.B.K.) Bailey). I. Latossolo Amarelo, textura médiaa. Acta Amazônica, v. 10, n.2, p.245-249, 1980.

FERREIRA, S. A. N.; CLEMENT, C. R.; RANZANI, S. S. C. Contribuição para o conhecimento do sistema radicular da pupunheira (Bactris gasipaes H.B.K., Palmae) II. Solo latossolo amarelo, textura argilosa. Acta Amazônica, v. 25, n.3/4, p.161170, Jul. 1996.

FERREIRA, V. L. P. Caracterização físico-quimico-bioquímica e organoléptica do palmito proveniente da palmeira Guilielma gasipaes Bayle (pupunha) em relação ao palmito da palmeira Euterpe edulis Mart (juçara). Piracicaba, 1982. 73p. Dissertação (Mestrado) - Escola Superior de Agricultura "Luiz de Queiróz", Universidade de São Paulo.

FNP CONSULTORIA E COMERCIO. Agrianiual - 1996. São Paulo, 1996. p.307-312. 
GUANDIQUE, M. E. G. Balanço hídrico no solo e consumo de àgua pela cultura de feijão (Phaseolus vulgaris L.) irrigado. Piracicaba, 1993. 94p. Dissertação (Mestrado) - Escola Superior de Agricultura "Luiz de Queiroz", Lniversidade de São Paulo.

HOAGLIN, D.C.; MOSTELLER, F \& TUKEY, J. W. Understanding Robust and Exploratory Data Analysis. New York: John Wiley \& Sons, 1982. 447p.

JANUÁRIO, M. Balanços hídrico e de energia e a resposta fisiológica para a cultura de trigo (Triticum aestivum L.). Piracicaba, 199211 p. Dissertação (Mestrado) - Escola Superior de Agricultura "Luiz de Queiroz", Universidade de São Paulo.

JENSEN, M. E. Evaluating irrigation efficiency. Journal of Irrigation and Drainage Division, v. 93, p.83-98, Mar 1967.

KALMA, J. D.; STANHILL, G. Transpiration, evaporation and deep drainage losses from an orange plantation. Israel Journal of Agricultural Research, v. 19, p. 11-24, Jan. 1969.

KELLER, J.; KARMELI, D. Trickle irrigation design. local: Rain Bird Sprinkler Manufacturing Corporation, 1975. 133p.

LIBARDI, P. L. Dinâmica da água no solo. Piracicaba: ESALQ, Depto. Física e Meteorologia, 1995. 497p.

LIBARDI, P. L.; REICHARDT, K.; NIELSEN, D. R. et al. Simple field methods for estimating soil hydraulic conductivity. Soil Science Society of America Journal, v.44, p.3-7, 1980. 
LUCHIARI JUNIOR, A. A determinação do coeficiente de cultura $(\mathrm{Kc})$ para feijão (Phaseolus vulgaris L.) pelo método do balanço hídrico. Piracicaba, 1978. 59p. Dissertação (Mestrado) - Escola Superior de Agricultura "Luiz de Queiroz", Universidade de São Paulo.

MAGALHÃES, A. C. N. Análise quantitativa do crescimento. In: Fisiologia vegetal. São Paulo: EPU; EDUSP, 1979. v.1, p.331-350.

MARTHALER, H. P.; VOGELSANGER, W.; RICHARD, F.; WIERENGA, P. J. et al. A pressure transducer for field tensiometers. Soil Science Society of America Journal, v. 47, n.4, p.624-627, 1983.

MORA URPI, J. El pejibaye (Bactris gasipaes $\mathrm{HBK}$ ): origen, biologia floral y manejo agronómico. In: PALMERAS POCO UTILIZADAS DE AMÉRICA TROPICAL. Turrialba: FAO/CATIE, 1984. p.118-160.

MORALES, A.L.; VARGAS, H.S. Observaciones sobre la distribuicion radical del Pejibaye (Bactris gasipaes HBK) para palmito en un Andosol. Revista de la Corporación Bananera Nacional, v. 14, n.34, p.9-15, 1990.

NELLIAT, E. V. Effect of frequency of irrigation on newly planted young coconut palms in sandy soil. Indian Journal of Agricultural Science, v.38, n.4, p. 737-746, Jan. 1968.

OMETTO, J. C. Bioclimatologia vegetal. São Paulo: Agronômica Ceres, 1981. 440p. 
PEREIRA, A. R.; BARROS FERRAZ, E. S.; REICHARDT, K. et al. Estimativa da evapotranspiração e da drenagem profunda em cafezais cultivados em solos podzolizados Lins e Marília. Piracicaba, CENA, 1974. 13p. (CENA, Boletim Científico, BC-014).

$\mathrm{RAO}$, A. S. Water requeriments of young coconut palms in a humid tropical climate. Irrigation Science, v. 10, p.245-249, 1988.

REICHARDT, K. Processos de transferência no sistema solo-planta-atmosfera. Campinas: Fundação Cargill, 1985. 445p.

REICHARDT, K.; LIBARDI, P. L.; SANTOS, J. M. An analysis of soil water moviment in the field. II. Water balance in snap bean crop. Piracicaba: CENA, 1974. 14p. (CENA. Boletim Cientifico, BC-022).

REICHARDT, K.; LIBARDI, P. L.; SAUNDERS, L. C. V.; CADINA, A. C. et al. A dinâmica da água em solo cultivado com milho. Revista Brasileira de Ciência do Solo, v.3, p.1-5, jan/abr 1979.

RENESTO, O. V. \& VIEIRA, L. A. Análise econômica da produção e processamento de palmito em conserva nas regiões sudeste e sul do Brasil. Campinas: ITAL, 1977, 39p. (Estudos econômicos: alimentos processados, 6).

RICHARDS, L. A. The usefulness of capilary potential to soil moisture and plant investigators. Journal Agricultural Research. v.37, p.719-742, 1928.

ROGNON, F. Production du matériel végétal cocotier. Sélection au stade germoir. Oléagineux, v.27, n.1, p.21-23, 1972 b. 
ROGNON, F. Production du matériel végétal cocotier. Sélection des hybrides en germorr. Oléagineux, v.27, n.4, p.203-204, 1972a.

ROSE, C.W. Agricultural physics. Oxford: Pergamon Press, 1966. 230p.

SAKAI, E. Balanço hídrico e energético na cultura do feijoeiro em latossolo roxo. Piracicaba, 1989. 121p. Dissertação (Mestrado) - Escola Superior de Agricultura "Luiz de Queiroz", Universidade de São Paulo.

SILVA, F. C. Uso de dispositivos lisimétricos para medida da evapotranspiração de referência. Piracicaba, 1996, 73p. Dissertação (Mestrado) - Escola Superior de Agricultura "Luiz de Queiroz", Universidade de São Paulo.

SINGH, P.; WOLKEWITZ, J.; KULMAR, R. Comparative performance of different crop production functions for wheat (Triticum aestivum L.) Irrigation Science, v.8, p.273-290, 1987.

SLATYER, R. O. Plant water relationships. New York: Academic Press, 1967. 366p.

VAN GENUCHTEN, M. T. A closed form equation for predicting the hydraulic conductivity of unsaturates soils. Soil Science Society of America Journal, v 44: p. 892-898, 1980.

VIEIRA, D. B. As técnicas de irrigação., São Paulo: Editora Globo, 1989. 263p.

VILLA NOVA, N. A. Estudo sobre o balanço de energia em cultura de arroz. Piracicaba, 1973. 77p. Tese (Livre Docência) - Escola Superior de Agricultura "Luiz de Queiros", Universidade de São Paulo. 
VILLACHICA, L. Cultivo del Pijuayo (Bactris gasipaes Kunth) para palmito en la Amazonia. Tratado de Cooperacion Amazonica, 1996. 146P.

VIZQUEZ, N. F. S. Aspectos fenológicos de pejibaye (Bactris gasipaes H.B.K.). Costa Rica, 1981.60p. Dissertação (Mestrado) - Universidade da Costa Rica 